\title{
Mercury Emissions From Municipal Solid Waste Combustors
}

\section{An Assessment of the Current Situation in the United States and Forecast of Future Emissions}

Solid Waste Association of North America Silver Spring, Maryland

NREL Technical Monitor: Philip Shepherd

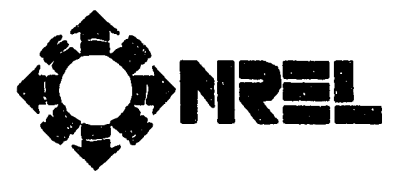

National Renewable Energy Laboratory

(formerly the Solar Energy Research Institute) 1617 Cole Boulevard

Golden, Colorado 80401-3393

Operated by the Midwest Research Institute for the U.S. Department of Energy under Contract No. DE-AC02-83CH10093

May 1993

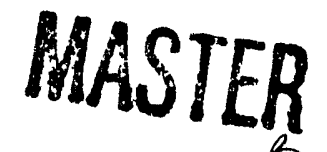




\section{NOTICE}

NOTICE: This report was prepared as an account of work sponsored by an agency of the United States government. Neither the United States government nor any agency thereof, nor any of their employees, makes any warranty, express or implied, or assumes any legal liability or responsibility for the accuracy. completeness, or usetulness of any information, apparatus, product, or process disclosed, or represents that its use would not infringe privately owned rights. Reference herein to any specific commercial product, process, or service by trade name, trademark, manutacturer, or otherwise does not necessarily constitute or imply its endorsement, recommendation, or favoring by the United States government or any agency thereof. The views and opinions of authors expressed herein do not necessarily state or reflect those of the United States government or any agency thereof.

Printed in the United States of America

Available from:

National Tecthical Information Service

U.S. Deparument of Commerce

5285 Port Royal Road

Springfield, VA 22161

Price: Microfiche A01

Printed Copy A06

Codes are used for pricing all publications. The code is determined by the number of pages in the publication. Information pertaining to the pricing codes can be found in the current issue of the following publications which are generally available in most libraries: Energy Research Abstracts (ERA): Government Reports Announcements and Index (GRA and I); Scientitic and Technical Abstract Reports (STAR); and publication NTIS-PR-360 available from NTIS at the above address. 


\section{PREFACE}

This report examines issues related to emissions of mercury from municipal solid waste (MSW) combustors. This report is based upon an examination and analysis of currently available literature.

The report provides a generalized forecast of potential emissions reductions. The forecast is based on assumptions for reducing the amount of mercury that enters MSW combustors, and achievement of various levels of air pollution control equipment efficiencies.

The report consists of a composite summary discussion of issues. It also includes illustrative annexed materials, selected tc provide more in-depth information on specifis aspects of mercury emissions issues. This report is principally concerned with source strength characterization. It does not attempt to address the fate and transport of mercury in the environment, nor does it undertake any hazard or risk analyses. 
This page intentionally blank. 
TABLE OF CONTENTS

Page

Executive Summary $\ldots \ldots \ldots \ldots \ldots \ldots \ldots \ldots \ldots \ldots \ldots$

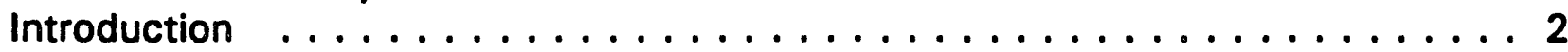

Mercury in the Environment $\ldots \ldots \ldots \ldots \ldots \ldots \ldots \ldots \ldots$

Mercury in Municipal Solid Waste $\ldots \ldots \ldots \ldots \ldots \ldots \ldots \ldots$

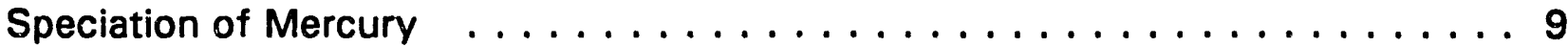

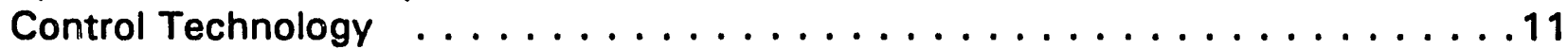

Mercury in Residues . . . . . . . . . . . . . . . . . . . 14

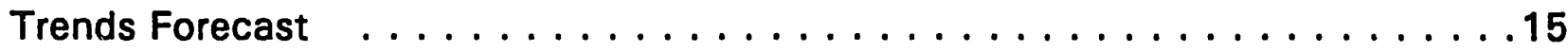

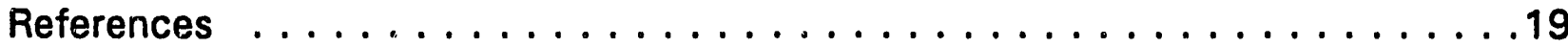

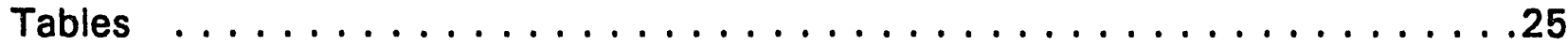

ANNEX I - Abstracted Literature $\ldots \ldots \ldots \ldots \ldots \ldots \ldots \ldots$ 
This page intentionally blank. 


\section{TABLES}

TABLE I:

TABLE \|:

TABLE III:

TABLE IV:

TABLE V:

TABLE VI(a):

TABLE VI(b):

TABLE VII:

TABLE VIII:

TABLE IX(a):

TABLE IX(b):

TABLE IX(c):

TABLE IX(d):

Worldwide anthropogenic sources of mercury

Page (tonnes/year) . . . . . . . . . . . . . . . . 25

Estimated amount $(\mathrm{g}-\mathrm{Hg} / \mathrm{tonne} \mathrm{MSW})$ of mercury $(\mathrm{Hg})$ in MSW. . . . . . . . . . . . . . . . . . 26

Estimated amount (tonnes) of mercury in products in MSW (a). . . . . . . . . . . . . . . . . . . . . 27

Total estimated amount (tonnes) of mercury in MSW that is combusted. . . . . . . . . . . . . . . . . . 28

Estimated amount (tonnes) of mercury in products in combusted MSW (a). . . . . . . . . . . . . . . . . . . . . 29

Estimated amount ( $\mathrm{g}-\mathrm{Hg} /$ tonne MSW) of mercury in combusted MSW. . . .....................30

Estimated amount (tonnes) of mercury in combusted MSW . 31

Estimated number of units of disposed consumer products that together contain one tonne of mercury. . . . . . . . 32

Estimated impact of nominal handling costs upon total cost of avoiding disposal of one tonne of mercury. . . . . . . . 33

Estimated amount (tonnes) of mercury emitted from combusted MSW (1995) at various levels of air pollution control (APC) . 34

Estimated amount (tonnes) of mercury emitted from combusted MSW (2000) at various levels of air pollution control (APC) . 35

Estimated percent reduction in mercury emissions in the year 1995 at various levels of air pollution control (APC) compared to 1989 unabated emissions baseline (b) . . . . . . . . 36

Estimated percent reduction in mercury emissions in the year 2000 at various levels of air pollution control (APC) compared to 1989 unabated emissions baseline (b) . . . . . . . . . 37 
TABLE X: $\quad$ Cost estimates for removing one tonne of mercury at various levels of mercury in MSW feed using add-on activated carbon control technology . . . . . . . . . . . . . . 38

TABLE XI(a): Amount ( $\mathrm{g}-\mathrm{Hg}$ /tonne ash) of mercury reported found in ash residue samples at ash disposal sites in the United States. . . . . . . 39

TABLE XI(b): Mercury levels (micrograms $\mathrm{Hg}$ /liter of leachate) reported found in leachate collected at the Woodburn ash monofill site, Woodburn, Oregon. ......................40

TABLE XII: $\quad$ Estimated concentration (micrograms per cubic meter) of mercury in exhaust gas of MSW combustor as a function of amount of mercury ( $\mathrm{g}-\mathrm{Hg} /$ tonne MSW) in MSW feedstock and APC removal efficiency. ...................41 


\section{EXECUTIVE SUMMARY}

This report examines emissions of mercury $(\mathrm{Hg})$ from municipal solid waste (MSW) combustion in the United States (U.S.). It is projected that total annual nationwide MSW combustor emissions of mercury could decrease from about 97 tonnes 11989 baseline uncontrolled emissions) to less than about 4 tonnes in the year 2000. This represents approximately a 95 percent reduction in the amount of mercury emitted from combusted MSW compared to the 1989 mercury emissions baseline.

Given: (a) current and projected trends in reduction of amounts of mercury in fluorescent lamps; (b) apparently promising prospects for diverting most cylindershaped mercury-zinc (CSMZ) batteries used in various hospital applications from municipal solid waste (MSW); and (c) the likelihood that routinely achievable mercury emissions removal efficiencies of about $\mathbf{8 0}$ percent or more can be assured; it is estimated that MSW combustors in the U.S. could prove to be a comparatively minor source of mercury emissions after about 1995. This forecast assumes that diligent measures to control mercury emissions, such as via use of supplemental control technologies (e.g., carbon adsorption), are generally employed at that time. However, no present consensus was found that such emissions control measures can be implemented industry-wide in the U.S. within this time frame. Although the availability of technology is apparently not a limiting factor, practical implementation of necessary control technology may be limited by administrative constraints and other considerations (e.g., planning, budgeting, regulatory compliance requirements, etc.).

These projections assume that: (a) about 80 percent mercury emissions reduction control efficiency is achieved with air pollution control equipment likely to be employed by that time; (b) most cylinder-shaped mercury-zinc (CSMZ) batteries used in hospital applications can be prevented from being disposed into the MSW stream or are replaced with alternative batteries that do not contain mercury; and (c) either the amount of mercury used in fluorescent lamps is decreased to an industry-wide average of about $\mathbf{2 7}$ milligrams of mercury per lamp or extensive diversion from the MSW stream of fluorescent lamps that contain mercury is accomplished.

If nominal control efficiencies of about 90 percent could be achieved, in conjunction with other assumptions, total annual nationwide mercury emissions from MSW combustors may be reduced to about 2 tonnes by the year 2000. This represents approximately a 98 percent reduction in the amount of mercury emitted from combusted MSW compared to the 1989 (unabated) mercury emissions baseline. While it appears that this level of mercury emissions reduction control is technologically possible at the present time, it is impractical to expect general industry-wide routine achievement of these average control efficiencies without the passage of some period of time. Historically there have been time lags in response to enacting legislation. Significant time may elapse before complete industry-wide 
compliance (inclusive of both new and existing MSW combustor facilities) is achieved. However, new and recently constructed MSW combustor facilities likely could achieve projected control efficiencies much more quickly than older facilities.

Note that compared to the above projected levels of mercury emissions from MSW combustors, emissions of mercury from fossil fuel burning in the United States currently amount to about 300 tonnes of mercury released to the atmosphere. Absent control or preventative measures to reduce such emissions from fossil fuelbased systems, as coal continues to increase its share of the energy market, levels of these emissions may increase.

\section{INTRODUCTION}

This report is an in-depth examination of current information concerning mercury emissions from MSW combustors. It addresses several technical issues that are relevant to the current situation, projects future trends in emissions from MSW combustor facilities, examines the strength of the present data base, and indicates implications for mitigation of the source strength of these facilities.

Issues that are addressed relate specifically to the source strength of MSW combustors, i.e., mercury in the waste stream that is fed to MSW combustors, the performance behavior of these facilities, the potential for occurrence of mercury emissions from MSW combustor ash residue, and potential trends or options for emissions abatement. No attempt has been made to assess the subsequent fate and transport of mercury emissions. Such an analysis is outside the scope of this report, which is intended to be principally concerned with source characterization.

Technical issues that relate to MSW combustor mercury emissions have been identified. In this report, these issues have been organized as follows:

Mercury in the environment: How do mercury emissions from combustors compare to other anthropogenic (refers to perturbations of nature which derive from, relate to, or are influenced by human impacts) emissions sources or to non-anthropogenic (not derived from, related to, or influenced by human impacts) sources of mercury? What is the quality of the data base that relates to this issue?

Mercury in MSW: What are significant sources of mercury in MSW that is combusted? Aie amounts of mercury in these sources changing? What impacts may be realized if amounts of mercury in MSW that is combusted are reduced to specific target reduction levels? What economic cost considerations may ensue if various source reduction strategies are pursued? 
Speciation of mercury: What is known about mercury speciation (the transformation of mercury compounds from one form to another) during MSW combustion? What challenges to emissions control technology are posed as a result of speciation of mercury?

Control technology: What is the current situation in regard to mercury emissions control technology? Are there apparent trends in regard to control technologies? What control technologies are being developed? What emissions reduction impacts may be realized if various levels of control are achieved?

Mercury in residues: What happens to mercury in MSW combustor residues? What indications of mercury leachability are apparent? Under what circumstances might mercury not be retained in residues?

Trends forecast: Based on the above considerations, what may be the likely trend in regard to mercury emissions from MSW combustors? If the trend predicted is realized, what are the comparative benefits or consequences to the environment of mitigation of all anthropogenic emissions sources?

These technical issues have been addressed by undertaking several tasks. An extensive literature search was carried out. Data and information that relate to these issues have been abstracted, assembled, examined and analyzed. This examination provides a composite representation of the present situation.

Tables of data that show reported information or provide estimates of parameters related to MSW combustors have been assembled from referenced literature. These tables are presented at the end of this discussion, and provide information on possible trends in regard to the source characterization of MSW combustion, and its relation to potential emissions levels.

\section{MERCURY IN THE ENVIRONMENT}

In the United States and elsewhere, release of mercury to the environment, including that which results from MSW combustion, has been an issue of concern among international, national, state and local governments. It is also of concern to the public, and has been the subject of numerous media reports. Data estimates reported in Table I indicate possible anthropogenic sources of mercury [1]. Some segments of the public consider mercury emissions to be unacceptable, and means are being explored in order to understand how, and to what extent, it may be possible to prevent or mitigate future releases of mercury.

Based on presently available data regarding anthropogenic sources of mercury emissions to the environment, it has been determined that MSW combustion is a 
major point-source of such emissions. For example, data recently developed in support of the now defunct plan to construct a MSW combustor in Los Angeles [2] indicate that, based upon then available information and emissions estimates, mercury emissions from the proposed facility, if constructed, could have been expected to exceed the sum of all other known ambient sources of mercury emissions in the surrounding area.

A recent report of findings and opinions of a group of technical experts [3] indicates that the uncontrolled release of mercury from MSW combustion can be a significant point source of mercury emissions to the environment. Moreover, this sam. group of experts has stated that this situation is unacceptable, and has recommended that further actions must be undertaken in order to prevent such uncontrolled release of mercury from MSW combustor facilities in the future.

It appears that data regarding emissions inventories from various types of emissions sources are frequently unavailable, incomplete, or of a quality that is limited. Consequently, there is difficulty in establishing a consensus opinion regarding, for example, what the relative amounts of mercury in the environment that derive from anthropogenic sources compared to non-anthropogenic sources are. Moreover, it is not evident that all sources of mercury emissions have yet been identified.

These circumstances can create difficulties for investigators who attempt to determine or forecast the relative contribution of MSW combustor emissions of mercury to the total flux (flow) of mercury to the environment. In addition, this situation creates difficulties associated with goals and objectives that address the more general issue of management of mercury.

Therefore, as a cautionary note, presently available data should be considered to be of uncertain quality. More definitive conclusions would benefit from further data development efforts. All information contained in this discussion should be viewed ii! this context. In particular, consensus should not, and cannot be presumed.

\section{MERCURY IN MUNICIPAL SOLID WASTE}

Various investigators have reported estimates of the amount of mercury in MSW. Representative data are indicated in Table II.

Based on recent source inventory analyses carried out in the United States, it has been estimated that batteries (nercury-zinc and alkaline) and fluorescent lamps constitute the major sources of mercury in MSW. [Note: The vases for these projections are discussed in detail in a recent U.S. EPA report [6].] Table III reports estimates and projections of amounts of mercury (tonnes) in MSW that are associated with materials in the waste stream. Although alkaline batteries (usually cylinder- 
shaped batteries used in flashlights, radios, electronics, toys, etc.) accounted for about 59 percent of the discards of mercury in 1989, the contribution to MSW from this source category is expected to decrease dramatically. This is due largely to battery industry actions being undertaken to reduce (to 0.025 weight percent per battery by 1992) and eventually eliminate all mercury from these batteries [6]. However, mercury-zinc batteries, including CSMZ batteries (e.g., as used in hospital applications - oxygen and fetal monitors, portable EKG monitors, etc.) and buttonshaped batteries (e.g., as used in transistorized equipment, hearing aids, electronic watches, pocket calculators, cameras, radios, etc.) are estimated to continue to be a major source of mercury in MSW.

The total estimated amount of mercury in MSW that is currently combusted, or projected to be combusted, in the United States can be derived from: (a) data estimates reported in the literature regarding total amounts of mercury in MSW, (b) projected amounts of MSW likely to be generated, and (c) projected amounts of MSW likely to be combusted. These estimates of total mercury in MSW that is combusted are reported in Table IV. Other estimates are possible. These are the estimates utilized in this report to make trends forecasts regarding MSW combustor emissions of mercury. The estimates shown in Table IV are generalized estimates, i.e., it is assumed that the level ( $\mathrm{g}-\mathrm{Hg} / \mathrm{tonne}$ MSW) of mercury in MSW that is combusted is comparable to the level of mercury in the MSW stream taken as a whole.

Data derived or reported in Tables III and IV can be used to estimate amounts of mercury in combusted MSW that are associated with specific disposed consumer products. This information is presented in Table $\mathrm{V}$. This table illustrates how changes in product composition (i.e., the amount of mercury in a product) influence the amount of mercury that gets into the combusted MSW stream.

Changes in the amount of mercury in the combusted MSW stream can also occur if diversion (preventing post-consumer products from being disposed, e.g., through recycling initiatives) and/or front-end removal (removing targeted, disposed postconsumer products from the MSW stream) are carried out. Tables VI(a) and VI(b) suggest how mercury in the combusted MSW stream may be influenced if target levels of diversion/removal are accomplished. The examples illustrated in these tables address the diversion/removal of mercury-zinc batteries (CSMZ and button-shaped) and fluorescent lamps, which are forecast to be the major sources of mercury in the MSW stream.

Regardless of whether substantial emissions reduction data are actually available, common sense suggests that if amounts of mercury in disposed consumer products are reduced, or waste diversion/removal is undertaken to limit the amount of mercury contained in MSW that is combusted, emissions reductions ought to be realized. Unfortunately, it is difficult to reliably forecast mercury emissions removal efficiencies that are likely to be achieved by actions that occur before MSW is combusted. 
Independent of diversion/removal practices that are associated with MSW management, mercury thermometers are gradually being replaced by digital thermometers [6]. Similarly, thermostats that utilize mercury switches are decreasing in use as alternative systems are utilized [7]. These are market-place changes that occur independent of MSW management practices. [Note: Mercury thermometers have been estimated to have a service life of 5 years; thermostats have been estimated to have a service life of 20 years. [6].] Moreover, the amount of mercury used in the manufacture of alkaline batteries is being rapidly decreased, regardless of MSW management practices. These changes are reflected in data presented in Tables III and V.

It is instructive to understand how many units of a post-consumer product need to be diverted/removed in order to prevent the placement of one tonne of mercurycontaining material in the MSW stream, or the subsequent release (e.g., atmospheric emissions, inputs into aquatic systems, emissions into soils) of mercury to the environment. Information on several post-consumer products is indicated in Table VII. The estimates are derived from the cited literature and presume no significant loss of mercury content when the objects are disposed. These numerical estimates may be underestimated; for example, in the case when fluorescent lamps are broken and mercury loss to the environment may occur prior to diversion/removal of these objects.

Examination of Table VII suggests that if the objective is to prevent disposal or combustion of one tonne of mercury, absent variations in handling complexities and costs, it is more worthwhile to target diversion/removal of mercury-zinc batteries than to target diversion/removal of alkaline batteries or fluorescent lamps. For example, Table VII estimates that 5,800,000 alkaline batteries must be removed to divert one tonne of mercury from the waste stream, whereas only 420,000 mercury-zinc batteries must be removed to divert the same tonne of mercury. However, such conclusions should be drawn with care.

For example, in one respect, fluorescent lamps are larger and thus possibly more easily handled in diversion/removal operations than mercury-zinc batteries, which can be difficult to remove with sorting equipment [7]. On the other hand, fluorescent lamps are easily broken, which can complicate removal of such material from MSW. Moreover, loss of mercury to the environment as a result of breakage may complicate prevention objectives. While recycling of these materials prior to their disposal into MSW is considered desirable, very little diversion/removal of fluorescent lamps is carried out in the United States [6].

As an additional consideration, it is reported [8] that the amount of mercury used in a standard four foot long (about 1.2 meters), one and one-half inch (about 3.8 centimeters) diameter cool-white fluorescent lamp has decreased from 48 milligrams 
of mercury used in 1985, to 42 milligrams of mercury used in 1990. This amount is projected to be decreased further to 27 milligrams of mercury used per lamp in 1995.

Current and projected mercury reductions are attributed to use of more efficient dosing techniques (employed during the manufacturing process) incorporated into newer high speed production equipment [8]. it has been reported that the projected figure for 1995 of 27 milligrams of mercury used in a U.S. standard four-foot fluorescent lamp is close to the present practical limit needed for efficient lighting performance [8]. Apparently, further reductions below this limit are dependent upon further technological innovations.

These estimates of mercury in fluorescerit lamps, if they can be considered representative of the average amount of mercury found in fluorescen: lamps taken as a whole, imply that reductions in the total amount of mercury associated with fluorescent lamps in MSW that is combusted, could be decreasing more rapidly than estimates reported in Table V. For example, if in the year 2000 about 700 million fluorescent lamps, which on average contained 27 milligrams of mercury per lamp, were disposed into MSW annually, this would be equivalent to the disposal of about 19 tonnes of mercury in the waste stream.

Under these circumstances, combustion of a projected total of $\mathbf{4 3}$ million tonnes of MSW in the year 2000 would include 4 tonnes of mercury due to disposed fluorescent lamps. This amount is about 50 percent less than the projected amount indicated in Table V. Again, it should be stressed that breakage of lamps when they are collected for disposal could imply that even less mercury occurs in MSW, but rather is released directly to the environment, regardless whether the disposal practice is direct landfilling of waste or combustion. Further investigation of this situation is warranted, as the implication is that there may be less mercury in MSW due to fluorescent lamps than is anticipated.

It is desirable to explore opportunities for diversion/removal of mercury-zinc batteries from the MSW stream, given that these batteries contain comparatively high levels of mercury per unit. However, as indicated, removal of these objects from MSW, once disposed, is difficult to accomplish. These observations notwithstanding, it is instructive to examine this situation more closely. [Note: Many European countries and Japan have battery return systems, which get the mercury-laden batteries into either a recovery of mercury chain or to a legal disposal as mercuric hazardous wastes. Reports of 75 to 90 percent removal from MSW streams are reported [9].]

As previously noted in this report, the category of disposed objects labelled "mercuryzinc" batteries is actually comprised of two types of batteries: (a) CSMZ (cylindershaped mercury-zinc) batteries, which are commonly used in hospitals; and (b) the smaller and more familiar type of button-shaped (flat cylindrical batteries), commonly 
used in watches, hearing aides, calculators, cameras, etc. Most significantly [6], it should be observed that while CSMZ batteries comprise only about 15 percent of the total amount of all mercury-zinc batteries in use now and projected through the year 2000, they have been estimated to contain more than 75 percent of the total amount of mercury in this category of disposed objects. This is because it is reported [6] that CSMZ batteries used in hospital applications contain about $\mathbf{1 4 . 2 6}$ grams of mercury per unit, while button-shaped batteries contain about 0.629 grams of mercury per unit.

Therefore, if CSMZ batteries could be diverted from the waste stream, a very significant reduction of mercury in MSW, which is attributable to the presence of mercury-zinc batteries, could be achieved. For example, complete diversion of CSMZ batteries from MSW could reduce levels attributable to the mercury-zinc battery category by more than 75 percent. This would comprise a very substantial reduction in the amount of mercury in MSW, particularly after about 1995, at which time, absent diversion of these batteries, the category mercury-zinc batteries is projected to contribute more than $\mathbf{5 0}$ percent of the total amount of mercury that is found in MSW and in MSW that is combusted. [Note: Collection of batteries in hospitals is currently practiced in Europe [9].]

A question that arises is whether nearly complete diversion from MSW of CSMZ batteries used in hospital applications is practical in the United States. [Note: Although it is presumed that most CSMZ batteries are disposed to MSW landfills [6], it is not clear to what extent these batteries may be disposed to hospital incinerators.] Broward County, Florida, has a population of about 1.2 million individuals, and absent diversion initiatives, health care services for the county population leads to the annual disposal of about $63,000 \mathrm{CSMZ}$ batteries to the MSW stream. However, a recent report [10] indicates that a rapidly developed and instituted hospital battery management program has been successfully carried out, in which nearly complete annual diversion of about 63,000 otherwise disposed CSMZ batteries has apparently been accomplished. [Note: The disposal of about 70,000 CSMZ batteries is equivalent to disposal of about one tonne of mercury.] As this program has been successfully carried out in a large test population, it is apparent that very high diversion rates of CSMZ batteries can be accomplished. It appears that more widespread institution of this approach could significantly reduce the amount of mercury found in the waste stream.

In summary, the use of alternative temperature measurement systems (digital thermometers), the use of alternative thermostats that do not incorporate use of mercury in circuitry, reductions in amounts of mercury in alkaline batteries, reductions in the amount of mercury used in fluorescent lamps, and a program aimed at diversion of CSMZ batteries from MSW should afford significant reductions in the amounts of mercury in MSW and in MSW that is combusted. 
It must be stressed that recovery and reuse of mercury from otherwise disposed objects could still lead to release of mercury to the environment if these practices are not carried out with appropriate preventative measures. Thus, responsibility for management of mercury in commerce should not be limited to considerations of consequences of disposal practices.

Diversion/removal costs for handling objects such as alkaline batteries, mercury-zinc batteries, fluorescent lamps, fever thermometers or thermostats are apparently not reliably known. It is difficult to provide estimates of the costs of these operations. However, sirice the number of units of any one of these types of consumed objects (that must be diverted in order to avoid the disposal of one tonne of mercury to MSW) can be estimated, it is possible to project the total cost of avoiding one tonne of mercury disposal associated with any particular type of object. This information is reported in Table VIII. In other words, while handling costs are not precisely known, the consequence of any nominal handling cost on avoiding disposal of mercury to the MSW stream can be projected. It is apparent from examination of Table VIII that such costs can be substantial. [Note: According to a recent report [11], in Marin County, California, a total of 434 fluorescent lamps were handled by a California lamp processor at a total cost of $\$ 303$ (U.S.), including transportation.] It must be stressed that the information provided in Table VIII is only intended to provide a range of estimates. It would be unreasonable to refer to the largest diversion costs indicated in the table, insert the words "up to" in front of them, and use these estimates of what it could cost to control mercury emissions. Much more refined data are needed before absolute costs estimates can be developed.

\section{SPECIATION OF MERCURY}

Examination of the flux (flow) of mercury through an MSW combustor indicates that practically all mercury contained in MSW that is combusted is mobilized into the flue gas stream [12]. Therefore, control measures to reduce emissions of mercury in flue gas are necessary if emissions are to be reduced.

Apparently, mercury occurs in MSW combustor post-combustion flue gas streams in three principal forms [13-16]: $\mathrm{Hg}(11)$, as mercuric chloride; $\mathrm{Hg}(\mathrm{ll}$, as mercurous chloride; and $\mathrm{Hg}(\mathrm{O})$, as elemental mercury. In one recent investigation [15] it was reported that about 80 percent of mercury in flue gas was present as mercuric chloride at the entrance to the air pollution control equipment. Other species are known, e.g., the oxide, $\mathrm{HgO}$ [17]. The characteristic physical and chemical properties and dynamic behavior of these species are important factors that must be considered in the design and operation of effective emissions control technologies.

The retention of mercury within control devices can be influenced by interactions (reactivity, adsorption behavior, etc.) of these species with materials of construction, 
deposits, and entrained matter in MSW combustor environments [15-17]. The environment and manner in which mercury species are bound up within, or in association with, solid substrates, e.g., residues, and their localized reactivity in these matrices, can have a profound effect upon species retention, reactivity and revolatilization [15-17]. Elemental mercury has proved to be difficult to capture and has posed a significant challenge in the design and operation of air pollution control devices.

As noted, other mercury species are known to occur in MSW combustor environments [17]. HgO may be of particular importance. For example, there is evidence $[17,18]$ that elemental mercury can be catalytically converted to $\mathrm{HgO}$ during interaction of elemental mercury and certain carbon based materials (e.g., some activated carbons) when oxygen is present. The oxide form $\mathrm{HgO}$ is significantly less mobile in association with solid substrates than is elemental mercury, and may present more favorable opportunity for effective capture and retention in control devices.

Experimental data at the laboratory scale suggest that the conversion of elemental mercury to its oxide in the presence of activated carbon is apparently temperature dependent, occurring readily at elevated temperature; for example, at 150 degrees Centigrade, within typical transit times of flue gas in an incinerator. On the other hand, these reports indicate that conversion can be comparatively slow at ambient temperatures (25 degrees Centigrade). These findings suggest that, absent other influences, control device temperature may be an important parameter and may be a limiting constraint upon reaction progress and mercury retention in regard to this particular reaction.

Other mercury compounds, e.g., the sulfide, HgS, are known to occur [17-19]. Some laboratory evidence suggests details of the nature of retention of the sulfide compound in association with solid matrices, such as may be found in MSW combustor environments [19]. Apparently, means are available to effectively retain this species. Research is underway that may provide information to enable identification, design and employment of practical and effective ways of converting mercury to the sulfide form, consistent with time scales and environments representative of MSW combustors [19]. Additional laboratory experiments are underway to allow utilization of this technology(s) [19].

An actual MSW combustor environment is far more complex than those that have been investigated in laboratory environments. Therefore, care is necessary in extrapolating results from the laboratory to practical application. Further investigations appear warranted in regard to details of the interaction dynamics and retention of $\mathrm{HgO}$ and other species on solid substrates.

Measurement methodology necessary for identifying mercury species in postcombustion flue gas streams and in association with solid matrices is sufficiently 
developed to allow determination of the partitioning of the principal mercury species in a quantitative manner. However, if precautions are not taken, the accuracy and precision of such measurements can be subject to considerable error, which has been discussed in some detail in literature reports $[16,20]$. For example, in one recent irivestigation [20] that compared the performance of two different methods used to measure mercury emissions, it was reported that results indicated significant precision and bias problems both within and between the methods. Investigators concluded that method development is needed. Reasons for some of these measurement problems have been identified $[16,20]$.

A consensus document that provides guidance regarding necessary precautions associated with measurements of mercury species in MSW combustor environments could be helpful, both as a means to communicate what is known (particularly in view of potential impacts of measurement error upon mass flux investigations) and to improve prospects for agreement concerning the utility of data that has been developed. Data that are collected must be analyzed carefully in order to understand influences of measurement errors [20] and possible reasons that errors may have occurred. For example, it was found in one reported instance that mercury removal efficiency can be overstated when sodium sulfide control technology is used [20], due to significant mercury retention on laboratory filters. Further, other investigators have reported [16] that the determination of mercury is among the most difficult of inorganic analyses because of its volatility, e.g., in regard to sample digestion and sample storage. Several independent methods of analysis are recommended. Interand intra-laboratory standardization of measurement practices may prove to be a beneficial exercise and should be pursued. Consensus, standardized measurement methods have not been established at the present time; rather, measurement practice appears dictated by regulatory policy $[21,22]$.

\section{CONTROL TECHNOLOGY}

The performance of conventional emissions control devices (e.g., acid gas scrubber/baghouse configurations) has not been entirely satisfactory to date for the capture of mercury species. In some instances, comparatively high capture efficiencies have been reported, while in other instances little or no effective capture of mercury species has been observed [23]. This situation may be changing as a more mature understanding of appropriate design and operation of these systems evolves. Progress has been confounded by the competitive nature of the MSW combustion market, which has led to a somewhat limited flow of information. However, in view of the reported [23] variability in emissions abatement that has been

achieved with these control measures (e.g., supplemental use of carbon adsorption injection technology), in some instances more control measures may be necessary to ensure effective abatement of emissions of mercury species. 
As noted, investigations of the behavior and performance of conventional control systems have been undertaken in order to evaluate mercury capture capabilities [1223]. In regard to combustion of refuse derived fuel, or in instances in which entrained matter in flue gas has significant carbon content, reports have suggested capture of mercury species at high efficiencies [24]. These observations and other influencing factors have led to exploration of supplemental control technologies that involve the use of carbon-based adsorbents and other materials [23]. [Note: Information concerning the subsequent behavior of mercury species in MSW combustor residue is discussed in the following section of this report.]

In summary, it appears that industry-wide routine, effective capture and retention of mercury species has not been attained and demonstrated via use of conventional air emissions control devices commonly used in the United States (e.g., electrostatic precipitators and baghouses with or without associated use of acid gas scrubbing equipment).

Wet scrubbers, sometimes augmented with chemical additives, have been used (e.g., in western Europe) as control devices in numerous instances. When coupled to MSW combustor facilities, these devices appear to offer prospects for substantial capture of mercury species, in some cases achleving reported efficiencies exceeding $\mathbf{8 0}$ - 90 percent $[15,25]$. Mercury speciation is a significant influencing factor in design of some systems. Subsequent treatment of captured species is carried out at some facilities. Extensive use of this system has not been realized in the United States. Concerns that remain include for example: (a) the [not well documented] possibility that dechlorination of chlorinated dibenzo-p-dioxins, which may occur in wet scrubbing devices, may shift the isomer distribution from the octa- form to more toxic tetra- forms; and (b) the implicit need to treat a regulated wastewater stream that is produced when wet scrubbers are employed.

Two supplemental control technologies that have received considerable interest in the United States are technologies that involve injection of either sodium sulfide or activated carbon-based adsorbents for capture of mercury species in flue gas streams $[23,26,27]$. It appears that the trend is towards utilization of activated carbon injection schemes. This preference may be partially motivated by perceived difficulties associated with handling and use of sodium sulfide $[21,22,26,27]$. Moreover, there is some evidence that the use of sodium sulfide may interfere with, and present difficulties in, making quantitative measurements of mercury capture efficiencies [20].

Based upon information that has been reported to date [20-27], it appears that the retention of mercury species with supplemental control technologies allows mercury emissions reductions in the range of $60-90$ percent. Control efficiencies in excess of 90 percent have been reported [23]. Control efficiencies of about $70-80$ percent appear to be routinely achievable, although at the present time there is no consensus. Higher control efficiencies have been reported, but it appears that industry-wide, 
routinely higher control efficiencies will be more difficult to achieve and appear to require increased levels of injected carbon. Variations in schemes to attack the problem of mercury control are evident $[23,28]$. A recent report [29] suggests that activated charcoal can catalyze formation of chlorinated dibenzo-p-dioxins (dioxins) from precursor compounds. However, in regard to control of mercury emissions from MSW combustors by carbon adsorption schemes, this does not appear to pose any major technological difficulties. At target operating temperatures for effective retention of mercury species (about $\mathbf{1 5 0}$ degrees Centigrade), the likely range of activation energies for the rate limiting step (site clearance), which controls the overall rate of formation of dioxins by catalysis, is such that dioxin generation is expected to be dramatically suppressed $[30,31]$.

The federal government in the United States is not likely to explicitly limit the choice of particular control technology(ies) required to be employed in abating emissions of mercury. However, the development of an emissions performance standard may be based upon injected activated carbon adsorption control technology as a frame of reference $[21,22]$.

Some emissions reductions forecasts, based upon nominal levels of achieved control technology, can be developed that take into consideration factors such as: (a) the amount of mercury projected to be found in MSW that is combusted; (b) the total amount of MSW forecast to be combusted in the future; and (c) potential emissions reductions that may be realized if certain levels of diversion/removal of post-consumer objects that contain mercury is accomplished. Tables IX(a) - IX(d) forecast MSW combustor emissions reductions that could be achieved at specified target control efficiencies.

Costs associated with employment of carbon adsorption control technologies appear to be in the range of $\$ 0.50$ (U.S.) - $\$ 1.00$ (U.S.) per tonne of MSW that is combusted $[21,22]$. As indicated in Table $X$, if mercury contamination in MSW that is fed to MSW combustors lies in the range of $0.5-5.0 \mathrm{~g}-\mathrm{Hg} /$ tonne MSW, the costs of controlling mercury emissions with this control technology could be in the range of about $\$ 100,000$ (U.S.) - $\$ 500,000$ (U.S.) per tonne of mercury emissions removed.

These cost estimates appear to be comparable to some of the potential front-end diversion/removal costs that are indicated in Table VIII. Further refinement of cost estimates appears warranted. No consensus is presently available regarding the reliability of these cost estimates. Moreover, a detailed consideration of the practicality of front-end processing approaches is necessary in order to establish to what extent technology, or confounding influences other than costs, limit front-end processing approaches.

In regard to front-end processing, mercury in disposed MSW may be mobile in some circumstances, whether landfilled or combusted $[17,28,32,33]$. For mercury 
contained in landfilled MSW, information does not appear sufficient to enable general forecasts of potential emissions of mercury in landfill gas or fugitive emissions. One investigator has suggested that although emissions of mercury from sanitary landfills are small, they may pose an environmental problem, because mercury emissions occur over a long period of time and are released from a large area [33]. Further investigations to collect data from field situations would be useful. However, the prospect that mercury may be released to the environment in landfill gas emissions $[32,33]$ suggests that diversion/removal strategies should generally address prevention of mercury in all MSW rather than merely focussing upon prevention of mercury in MSW that is combusted, particularly since both now and in the future, most MSW will be sent to landfills.

\section{MERCURY IN RESIDUES}

The future trend for mercury emissions control in the United States appears to be towards activated carbon-based adsorbents, in conjunction with use of acid gas scrubber/baghouse control devices. Mercury species that are captured through use of air pollution control devices and adsorbents are transferred to MSW combustor residue streams. A comprehensive examination of currently available literature suggests that causative factors leading to mobilization of mercury from residues due to, e.g., chemical disproportionation reactions (which can produce volatile mercury species [13,16]) and desorption of weakly bound mercury species [16], can be identified and can be mitigated through careful control of temperature, $\mathrm{pH}$, and other influencing parameters $[16,18,19,23]$.

For example, disproportionation reactions are, in part, responsive to $\mathrm{pH}$ control [16]. Moreover, retention of mercury species on carbon-based adsorbents is apparently sensitive to the temperature at which the carbon-based adsorbent is employed $[17,18,23]$. In other words, it appears that control technology exists, and means are available, which can ensure that mercury species are effectively retained in residues in a manner that can prevent any rapid remobilization of these species.

Recently, the stability of mercury in disposed ash/residue samples obtained from a scrubber/baghouse equipped MSW combustor (Stanislaus facility in California), which incorporates both thermal deNOx and activated carbon adsorption injection technologies, was investigated [23]. In these studies undertaken by the U.S. Environmental Protection Agency, investigators reported that results of analyses of a combined ash stream indicate that the mercury content of the ash/residue stream samples remained relatively constant over a period of 28 days when samples were held at a temperature of 54 degrees Centigrade. [Note: The temperature selected for heating the samples was assumed representative of the approximate upper end of elevated temperatures expected to occur in an ash monofill.] 
While it is known that in some circumstances mercury species can be immobilized for long periods of time in solids, e.g., peat moss at anaerobic conditions, the long-term leachability and mobilization of mercury species has not been extensively characterized. In the near term, leachate data from ash monofill sites suggests that the rate of release and amounts of mercury released from residues is apparently small compared to present regulatory standards [34-36]. Data regarding mercury in leachate from residues in ash monofills indicates that mercury, if present, occurs at levels markedly below present U.S. Environmental Protection Agency drinking water standards [36]. Tables $\mathrm{XI}(\mathrm{a})$ and $\mathrm{XI}(\mathrm{b})$ indicate mercury levels in ash and ash leachate.

\section{TRENDS FORECAST}

It appears that the amount of mercury in MSW may decrease from about $4 \mathrm{~g}-\mathrm{Hg} / \mathrm{tonne}$ MSW (1989) to about $0.8 \mathrm{~g}-\mathrm{Hg} / \mathrm{tonne}$ MSW by the year 2000, even without any attempts to remove or divert objects that contain mercury from MSW. These reductions relate to manufacturer initiatives aimed at reduction of the amount of mercury in alkaline batteries [6] and reduction of inventories of objects that contain significant amounts of mercury.

It has been projected that the amount of MSW combusted should increase from about 25 million tonnes in the year 1989 to about 43 million tonnes in the year 2000 [37]. In conjunction with projected decreases in the total amount of mercury in MSW, it can be anticipated that if no emissions of mercury from MSW combustors are prevented, the amount of mercury released to the environment from all MSW combustors may decrease from about 97 tonnes in 1989 to 33 tonnes in the year 2000.

If all mercury-zinc batteries and all fluorescent lights that contain mercury could be diverted from the MSW stream, it is estimated that the amount of mercury released from MSW combustors (assuming no air pollution control devices are employed that can prevent flue gas emissions), could be reduced to about 13 tonnes in the year 1995 and to about 6 tonnes in the year 2000. At present, however, there is no evidence that could lead to a confident expectation that such high rates of materials diversion can be achieved in a manner that is economically practical. This is based upon currently available technology and means to reduce the amounts of these materials in the MSW stream. Further diversion efforts would seem to be very useful to improve this situation.

It must be noted that diversion/removal of mercury containing objects from MSW combustors may not necessarily ensure that mercury contained in diverted objects can be prevented from being released to the environment. Mercury may escape from MSW landfills. It may escape when objects are damaged or broken, e.g., fluorescent lamps. It may escape during recovery and reprocessing for reuse. More 
comprehensive approaches to mitigate the release of mercury to the environment appear warranted if anthropogenic emissions of mercury are to be generally abated.

If no diversion/removal of mercury-containing materials from MSW is practical, mercury emissions from MSW combustors may be reduced by employment of air pollution control devices, inclusive of, but not limited to use of adsorbent injection schemes. If 80 percent of all mercury in MSW combustor flue gas could be captured, emissions of mercury could be reduced to about 7.6 tonnes in 1995 and to about 6.6 tonnes in the year 2000. A 90 percent removal efficiency could reduce MSW combustor emissions of mercury to about 3.3 tonnes by the year 2000. [Note: There is no present consensus that such emissions control measures can be implemented industry-wide in the U.S. within this time frame. Although the availability of technology is apparently not a limiting factor, practical implementation of necessary control technology may be limited by administrative constraints, planning, budgeting, regulatory compliance requirements, etc.]

In addition to a control efficiency of 90 percent, if there were complimentary means to divert from the MSW stream about 50 percent of all mercury-zinc batteries la prospect that appears feasible by institution of means to manage CSMZ batteries) and 50 percent of all fluorescent lamps (which may in any event be achieved if indeed the amount of mercury in these lamps is reduced to a level of $\mathbf{2 7}$ milligrams of mercury per lamp in the future), it appears that emissions could be further reduced to about 2 tonnes by the year 2000. This is to be compared to "baseline" uncontrolled, no diversion/removal MSW combustor emissions of mercury of about 97 tonnes in the year 1989. [Note Well: It is reported that about 5 percent of the total 6000 tonnes of mercury found in the atmosphere is attributed to emissions from fossil fuel burning in the United States [1,38-41]. This corresponds lassuming that the residence time for mercury in the atmosphere is about one year) to an annual emissions release of about $\mathbf{3 0 0}$ tonnes of mercury from fossil fuel burning in the United States.]

Possible MSW combustor exhaust gas stack emission levels of mercury have been estimated based upon a model MSW combustor described in recent literature [42]. It has the following characteristics: (a) the facility is designed to combust 454 tonnes of MSW per day and typically operates at about 80 percent of on-line capacity, corresponding to combustion of about 15.3 tonnes of MSW per hour; (b) the stack gas exit velocity is about $\mathbf{1 3}$ meters per second; (c) the stack exit diameter is about 1 meter; and (d) the exhaust gas exit temperature out of the stack is about 130 degrees Fahrenheit (328 degrees Kelvin).

Concentrations of mercury in the exhausted stack gas have been calculated by dividing the time-dependent mass of mercury (in micrograms per second units) fed into the model MSW combustor at the stated MSW feed rate, by the time-dependent volume of exhaust gas swept out of the stack (meters per second units). The 
projected emissions levels have been corrected to a reference temperature of 25 degrees Centigrade.

Approximate exhaust gas mercury emission concentration levels are reported in Table $\mathrm{XII}$ as a function of nominal average amounts of mercury contained in MSW that is combusted, and as a function of nominal mercury emissions control device removal efficiencies. These estimates assume that regardless of speciation, mercury is either emitted from the MSW combustor or it is retained in the control device. No other loss mechanisms for mercury are assumed.

These estimates indicate combinations of mercury emissions control device efficiencies and levels of mercury in MSW that, if achieved, may on average enable the possible levels of emissions reported in Table XII.

In view of apparent reported trends in reduction of amounts of mercury in fluorescent lamps [8] and apparently promising prospects for diverting CSMZ batteries from disposal into MSW [10], if routinely achievable mercury emissions control device removal efficiencies of about 80 percent or more can be assured, taken as a whole, MSW combustion in the United States could prove to be a comparatively minor source of mercury emissions to the environment after about 1995. Diligent measures to control mercury emissions, such as via use of supplemental control technologies (e.g., carbon adsorption), have the promise of ensuring that anticipated reduction levels can be realized.

Despice historic delays in regard to enactment of legislation, development of regulations or guidelines, and implementation of available technological options, it appears reasonable to anticipate that on average, by the year 2000 , more than a tenfold reduction in mercury emissions from MSW combustors can be achieved at modest costs. 
This page intentionally blank. 


\section{REFERENCES}

[1] J.O. Nriagu and J.M. Pacyna, "Quantitative Assessment of Worldwide Contamination of Air, Water and Soils by Trace Metals," Nature 333:134-139(1988).

[2] A.H. Smith et al., Health Risk Assessment of the LANCER Project, Volumes I-III, Berkeley, CA (1987).

[3] H. Yakowitz (Symposium Rapporteur), Incineration of Municipal Solid Waste: Scientific and Technical Evaluation of the State-of-Art (Executive Summary), Washington, DC (1990).

[4] P.W. Goetz (Editor-in-Chief) Encyclopedia Brittanica (15th Edition), Volume 8, New York (1990).

[5] P. Krenkel, "Mercury in the Environment: Methylation and Sediment Reactions," In: Proceedings of Workshop on Mercury Contamination in Florida: Impacts and Solutions, Tallahassee, FL (1990).

[6] A.T. Kearney, Inc. and Franklin Associates, Inc. (Contractors), Characterization of Products Containing Mercury in Municipal Solid Waste in the United States, 19702000 (Final Draft Deliverable), Submitted to L. Wynn, U.S. Environmental Protection Agency, Office of Solid Waste, EPA Contract No. 68-W9-0040, Washington, DC (1991), [Final report (with some modifications) issued as: U.S. EPA Report EPA 530R-92-013 (NTIS \# PB92-162569), Washington, DC, April 1992.]

[7] D. Hilton, H.G. Rigo and A.J. Chandler, "Composition and Size Distribution of a Blue-Box Separated Waste Stream," In: Proceedings, SWANA 6th Annual Waste-toEnergy Symoosium, Minneapolis, MN (1992).

[8] Y.D. Meyer, "Inter-Laboratory Testing for Mercury by TCLP and Source Reduction in the Lamp Manufacturing Industry," In: Arsenic and Mercury: Workshop on Removal. Recovery. Treatment and Disposal (Abstract Proceedings), Risk Reduction Engineering Laboratory, EPA, Cincinnati, OH (1992).

[9] H. Yakowitz (OECD, Paris, France), Private communication to W.M. Shaub, September 1992.

[10] J.L. Price, "Management of Medical Mercury Battery Wastes Through Source Substitution," In: Arsenic and Mercury: Workshoo on Removal, Recovery, Treatment and Disposal (Abstract Proceedings), Risk Reduction Engineering Laboratory, EPA, Cincinnati, OH (1992). 
[11] T. Watson, "Fluorescent lamps - a bright new recyclable," Resource Recycling, p. 74 (March 1992).

[12] P.H. Brunner and H. Monch, "The Flux of Metals Through Municipal Solid Waste Incinerators," Waste Management and Research 4:105-119(1986). [See also: P. Baccini and P.H. Brunner, Metabolism of the Atmosphere, Springer-Verlag, NY (1991).]

[13] J.G.T. Bergstrom, "Mercury Behavior in Flue Gases, "Waste Management and Research 4:57-64(1986).

[14] J.M. Pacyna and J. Munch, "Anthropogenic Mercury Emissions in Europe," Water, Air and Soil Pollution 56:51-63(1991).

[15] K. Nakazato, "Latest Technological Experience of the Removal of Mercury in Flue Gas and the Management of Fly Ash from MSW Incinerator[s]," Paper No. 100301-1990, National Waste Processing Conference - 14th Biennial Conference (1990).

[16] H. Vogg, H. Braun, M. Metzger and J. Schneider, "The Specific Role of Cadmium and Mercury in MSW," Waste Management and Research 4:65-74(1986).

[17] B. Hall, P. Schager and O. Lindqvist, "Chemical Reactions of Mercury in Combustion Flue Gases," Water, Air and Soil Pollution 56:3-14(1991).

[18] B. Gullet, "Mercury Capture Briefing," Presented at EPA Peer Review Meeting, U.S. EPA, Research Triangle Park, NC (1992).

[19] Y. Otani et al., "Removal of Mercury Vapor from Air with Sulfur-Impregnated Adsorbents," Environmental Science and Technology 22:711-717(1988).

[20] H.G Figo, personal communication to W.M. Shaub (1992). Based on Waste Analysis, Sampling, Testing and Evaluation (Waste Programl: Effect of Waste Stream Characteristics on MSW Incineration - The Fate and Behavior of Metals (Progress Print), Volume II, Burnaby, BC (1992).

[21] F. Porter et al., U.S. EPA Staff Briefing, Summary of September 6, 1991 Meting re Mercury Issues (and Annexed Materials), Washington, DC (1991).

[22] M.G. Johnson [Memorandum], "Mercury Testing at Municipal Waste Combustors," U.S. EPA, Research Triangle Park, NC (1990). 
[23] T.G. Brna,J.D. Kilgroe and C.A. Miller, "Reducing Mercury Emissions from Municipal Waste Combustion with Carbon Injection into Flue Gas," U.S. EPA, Research Triangle Park, NC, Presented at ECO World '92, Washington, DC (1992).

[24] R.M. Hartman and M.L. Smith, "The Beneficial Co-Existence of RDF Technology with Recycling and Environmental Protection Goals," In: Proceedings of 2nd U.S.Conference on MSW Management: Moving Ahead, U.S. EPA, Arlington, VA (1992).

[25] G. Jones, EDV Technology, Report prepared for: M.G. Johnson, U.S. EPA Research Triangle Park, NC (1990).

[26] D.M. White and K.L. Nebel, "Summary of Information Related to Mercury Emission Rates and Control Technologies Applied to Municipal Waste Combustors," Report prepared for: M.G. Johnson, U.S. EPA Research Triangle Park, NC (1990).

[27] M. Hereth, "Use of Sodium Sulfide for Mercury Control," Report to file, EPA Air Docket A-89-08 (IV-M-14), Washington, DC (1990).

[28] U. Cleve, "Application of Carbon Based Adsorbers for Washing of Flue Gases," Presented at the 1989 Incineration Conference, Knoxville, TN (1989).

[29] L.C. Dickson, D. Lenoir and O. Hutzinger, "Quantitative Comparison of de Novo and Precursor Formation of Polychlorinated Dibenzo-p-dioxins under Simulated Municipal Solid Waste Incinerator Postcombustion Conditions, " Environmental Science and Technology 26:1822-1828(1992).

[30] S.S. Penner, C.P. Li, M.B. Richards and D.F. Wiesanhahn, "A model for the de novo synthesis and decomposition rates of dioxins and furans in municipal waste incinerators," The Science of the Total Environment 104:35-46(1991).

[31] E.R. Altwicker, J.S. Schonberg, R.K.N.V. Konduri and M.S. Milligan, "Polychlorinated Dioxin/Furan Formation in Incinerators," Hazardous Waste and Hazardous Materials 1:73-88(1990).

[32] M. Lodenius and-H. Braunschweiler, "Volatilization of Heavy Metals from a Refuse Dump," The Science of the Total Environment 57:253-255(1986).

[33] M. Ettala, "Gaseous Impurities of the Working Air in Waste Treatment," In: Proceedings of the ISWA 6th International Solid Waste Congress and Exhibition, Madrid, Spain (1992).

[34] U.S. EPA, Characterization of Municipal Waste Combustion Ash, Ash Extracts and Leachates, EPA 530-SW-90-029A, Washington, DC (1990). 
[35] AWD Technologies, Ash and Leachates Characterization, Monofill 3rd Year Study, Pittsburgh, PA (1990).

[36] AWD Technologies, Ash and Leachates Characterization, Monofill 4th Year Study, Pittsburgh, PA (1992).

[37] U.S. EPA, "Characterization of MSW in the United States: 1990 Update (Executive Summary)," EPA 530-SW-90-042A, Washington, DC (1990); and update: U.S. EPA, "Characterization of MSW in the United States: 1992 Update (Executive Summary)," EPA 530-R-92-019, Washington, DC (1992).

[38] N. Revis, "Mercury Speciation: Impacts on Aquatic Toxicity," In: Proceedings of Workshop on Mercury Contamination in Florida: Impacts and Solutions, Tallahassee, FL (1990).

[39] W.F. Fitzgerald, "Atmospheric and Oceanic Cycling of Mercury," Chapter 57, In: Chemical Oceanugraphy (Volume 10), (1989).

[40] D. Porcella, "Mercury in the Environment," EPRI Journal 15:46-49(1990).

[41] W. Chow et al., "Managing Air Toxics," Paper No. 90.108.1, Presented at: 83rd Annual Air and Waste Management Association Meeting, Pittsburgh, PA (1990).

[42] K.A. Macoskey, A. Roffman and M.K. Lentz, "A Comparative Evaluation of Metal Emissions and Human Health Risks from Inhalation of Metals Emitted from Waste and Coal Combustors," AWD Technologies, Inc., Report No. 92-84.14, Pittsburgh, PA (1992).

[43] O. Lindqvist, "Fluxes of Mercury in the Swedish Environment: Contributions from Waste Incineration," Presented at: ISWA Specialized Seminar Incinerator Emissions of Heavy Metals and Particulates, Copenhagen, Denmark (1985).

[44] J.G.T. Bergstrom and J. Lindqvist, "Mercury Removal from Flue Gases from SYSAV's Waste Heat Boiler Plant in Malmo," Report DRAV Nr 20, Sweden (1985).

[45] D.O. Reimann,Waste Management and Research 10:37-46(1992).

[46] S. Cernuschi, M. Giugliano, I. de Paoli and H. Ghezzi, "The Flux of Residues and Heavy Metals Through a Municipal Solid Waste Incinerator," In" Proceedings of the ISWA 6th International Solid Waste Congress and Exhibition, Madrid, Spain (1992).

[47] Environment Canada (NITEP Program), "The Combustion Characterization of Mass Burning Incineration Technology," - Quebec City, Book No. 1, Volume IV, Canada (1987). 
[48] D.O. Reimann, "Mercury Output from Garbage Incineration," Waste Management and Research 4:45-56(1986).

[49] M. Rugg and N.K. Hanna, "Mercury Concentrations in MSW Components in Cape May County, NJ, In: Proceedings SWANA 6th Annual Waste-to-Energy Symposium, Minneapolis, MN (1992). 
This page intentionally blank. 


\begin{tabular}{|c|c|}
\hline Mercury Source & Emissions \\
\hline $\begin{array}{l}\text { Atmospheric Emissions } \\
\text { Coal combustion-electric utilities } \\
\text { Coal combustion-industry/domestic } \\
\text { Lead production } \\
\text { Copper-nickel production } \\
\text { Municipal refuse incineration } \\
\text { Sewags sludge incineration } \\
\text { Wood combustion } \\
\text { Total emissions } \\
\text { Median value }\end{array}$ & $\begin{array}{c}155-542 \\
495-2,970 \\
8-16 \\
37-207 \\
140-2,100 \\
15-60 \\
60-300 \\
910-6,200 \\
3,560\end{array}$ \\
\hline $\begin{array}{l}\text { Inputs into aquatic systems } \\
\text { Domestic wastewater-central } \\
\text { Domestic wastewater-noncentral } \\
\text { Steam electric } \\
\text { Base metal mining/dressing } \\
\text { Smelting/refining-nonferrous metals } \\
\text { Manufacturing processes-metals } \\
\text { Manufacturing processes-chemicals } \\
\text { Manufacturing processes-petroleum products } \\
\text { Atmospheric fallout } \\
\text { Dumping of sewage sludge } \\
\text { Total input, water } \\
\text { Median value }\end{array}$ & $\begin{array}{c}0-180 \\
0-420 \\
0-3,600 \\
0-150 \\
0-40 \\
0-750 \\
0.02-1,500 \\
0-20 \\
0.22-1,800 \\
0.01-310 \\
0.3-8,800 \\
4,600\end{array}$ \\
\hline $\begin{array}{l}\text { Emissions into soils } \\
\text { Agricultural and food wastes } \\
\text { Animal wastes, manure } \\
\text { Logging/other wood wastes } \\
\text { Urban refuse } \\
\text { Municipal sewage sludge } \\
\text { Solid wastes-metal manufacturing } \\
\text { Coal fly ash and bottom [fly] ash } \\
\text { Peat (agricultural and fuel uses) } \\
\text { Wastage of commercial products } \\
\text { Atmospheric fallout } \\
\text { Total input, soils } \\
\text { Median value } \\
\text { Mine tailings } \\
\text { Smelter slags and wastes } \\
\text { Total discharge on land }\end{array}$ & $\begin{array}{c}0-1,500 \\
0-200 \\
0-2,200 \\
0-260 \\
0.01-800 \\
0-80 \\
0.37-4,800 \\
0-20 \\
0.55-820 \\
0.63-4,300 \\
1.6-15,000 \\
8,300 \\
0.55-2,800 \\
0.05-280 \\
2.2-18,000\end{array}$ \\
\hline
\end{tabular}




\begin{tabular}{|c|c|c|}
\hline TABLE II: & \multicolumn{2}{|c|}{ Estimated amount (g-Hg/tonne MSW) of mercury $(\mathrm{Hg})$ in MSW. } \\
\hline g-Hg/tonne MSW & Location & Reference \\
\hline $\begin{array}{c}0.5-3.0 \\
5 \\
0.83(+/-0.81) \\
2 \\
2 \\
0.5-9 \\
0.3-14 \\
1.4-2.6 \\
1-7 \\
5 \\
\text { ca } 1 \\
0.36-1.05 \\
0.034-0.257 \\
3-4 \\
3.9 \\
5.8 \\
4.0\end{array}$ & $\begin{array}{l}\text { Sweden } \\
\text { Germany } \\
\text { Switzerland (a) } \\
\text { Switzerland (b) } \\
\text { Sweden } \\
\text { Europe } \\
\text { Europe } \\
\text { Italy } \\
\text { Europe (c) } \\
\text { Sweden (d) } \\
\text { Sweden (e) } \\
\text { Canada } \\
\text { USA (f) } \\
\text { Europe } \\
\text { USA (g) } \\
\text { USA (h) } \\
\text { USA (i) }\end{array}$ & $\begin{array}{c}\text { Lindqvist [43], } 1985 \\
\text { Vogg [16], } 1986 \\
\text { Brunner [12], } 1986 \\
\text { Brunner [12], } 1986 \\
\text { Bergstrom [44], } 1985 \\
\text { Pacyna [14], } 1991 \\
\text { Reimann [45], } 1992 \\
\text { Cernuschi [46], } 1992 \\
\text { Cernuschi [46], } 1992 \\
\text { Hall [17], 1991 } \\
\text { Hall [17], 1991 } \\
\text { Environment Canada [47], } 1987 \\
\text { Hartman [24], } 1992 \\
\text { Reimann [48], } 1986 \\
\text { Rugg [49], } 1992 \\
\text { Rugg [49], } 1992 \\
\text { EPA [6], } 1991\end{array}$ \\
\hline \multicolumn{3}{|c|}{$\begin{array}{l}\text { Notes: (a) with battery diversion program; (b) without battery diversion program; (c) } \\
\text { urban wastes; (d) industrialized area; (e) with battery diversion program; (f) refuse } \\
\text { derived fuel; (g) as received; (h) dry basis; (i) estimates derived, this report, from data } \\
\text { reported in cited reference. }\end{array}$} \\
\hline
\end{tabular}




\begin{tabular}{|l|c|c|c||}
\hline \multicolumn{4}{|c|}{ TABLE III: Estimated amount (tonnes) of mercury in products in MSW (a). } \\
\hline Product & 1989 & 1995 & 2000 \\
\hline Alkaline batteries (b) & 380 & 38 & 0 \\
Mercury-zinc batteries (c) & 180 & 120 & 90 \\
Other batteries & 5 & 3 & 0 \\
Fluorescent lamps & 24 & 30 & 36 \\
High intensity lamps & 0.7 & 1 & 1 \\
Fever thermometers & 15 & 15 & 15 \\
Thermostats & 10 & 7 & 9 \\
Pigments & 9 & 3 & 1 \\
Dental uses & 4 & 3 & 2 \\
Special coating paper & 1 & 0 & 0 \\
Mercury light switches & 0.4 & 2 & 2 \\
Film pack batteries & 0 & 0 & 0 \\
Paint residues & 16 & 2 & 0.5 \\
Total (d): & 645 & 224 & 157 \\
\hline Notes: (a) Data obtained from reference [6]; (b) household [e.g., D, C, AA, AAA, 9v.]; \\
(c) mercury-zinc batteries including button-shaped batteries (avg. g-Hg 0.629 g/battery) \\
and cylinder-shaped batteries (avg. Hg 14.265 g-Hg/battery); (d) some rounding off of \\
numbers. \\
\hline
\end{tabular}




\begin{tabular}{|c|c|c|c|}
\hline \multirow[t]{2}{*}{ TABLE IV: } & unt (tonnes) & reury in MSI & hat is \\
\hline & 1989 & 1995 & 2000 \\
\hline Total amount MSW & 166 million & 189 million & 201 million \\
\hline Amount MSW combusted & 24 million & 32 million & 43 million \\
\hline Total mercury in MSW & 645 & 224 & 157 \\
\hline Percent of total MSW combusted & 15 & 17 & 21 \\
\hline $\begin{array}{l}\text { Total amount of mercury in } \\
\text { combusted MSW }\end{array}$ & 97 & 38 & 33 \\
\hline
\end{tabular}




\begin{tabular}{|c|c|c|c|}
\hline \multicolumn{4}{|c|}{$\begin{array}{l}\text { Estimated amount (tonnes) of mercury in products in combusted } \\
\text { MSW (a). }\end{array}$} \\
\hline Product & 1989 & 1995 & 2000 \\
\hline $\begin{array}{l}\text { Alkaline batteries (b) } \\
\text { Mercury-zinc batteries (c) } \\
\text { Other batteries } \\
\text { Fluorescent lamps } \\
\text { High intensity lamps } \\
\text { Fever thermometers } \\
\text { Thermostats } \\
\text { Pigments } \\
\text { Dental uses } \\
\text { Special coating paper } \\
\text { Mercury light switches } \\
\text { Film pack batteries } \\
\text { Paint residues } \\
\text { Total (d): }\end{array}$ & $\begin{array}{l}57 \\
27 \\
0.8 \\
3.6 \\
0.1 \\
2.3 \\
1.5 \\
1 \\
0.6 \\
0.2 \\
0.1 \\
0 \\
2.4 \\
\\
97\end{array}$ & $\begin{array}{l}6.5 \\
20 \\
0.5 \\
5.1 \\
0.2 \\
2.6 \\
1 \\
0.5 \\
0.5 \\
0 \\
0.3 \\
0 \\
0.3 \\
38\end{array}$ & $\begin{array}{l}0 \\
19 \\
0 \\
7.6 \\
0.2 \\
3.2 \\
2 \\
0.2 \\
0.4 \\
0 \\
0.4 \\
0 \\
0.1 \\
\\
33\end{array}$ \\
\hline \multicolumn{4}{|c|}{$\begin{array}{l}\text { Notes: (a) Data derived from information presented in Tables III and IV; (b) household } \\
\text { [e.g., D, C, AA, AAA, 9v.]; (c) mercury-zinc batteries including button-shaped batteries } \\
\text { (avg. g-Hg O.629 g/battery) and cylinder-shaped batteries lavg. } \mathrm{Hg} 14.265 \mathrm{~g} \text { - } \\
\text { Hg/battery); (d) some rounding off of numbers. }\end{array}$} \\
\hline
\end{tabular}


TABLE VI(a): Estimated amount ( $\mathrm{g}-\mathrm{Hg} /$ tonne MSW) of mercury in combusted MSW.

\begin{tabular}{|l|r|r|r|}
\hline Material Removed/diverted (a) & 1989 & 1995 & 2000 \\
\hline None (b) & 4.0 & 1.2 & .8 \\
$100 \%$ B & & .6 & .3 \\
$100 \%$ L & & 1.0 & .6 \\
$100 \%(B+L)$ & & .4 & .1 \\
$50 \%$ B & & .9 & .5 \\
$50 \%$ L & 1.1 & .7 \\
$50 \%(B+L)$ & & .8 & .5 \\
\hline
\end{tabular}

Notes: (a) $B$ = all mercury-zinc batteries, $L$ = all fluorescent lamps; (b) Data derived from information in Tables III-V. 


\begin{tabular}{||l|c|c|c||}
\hline \multicolumn{3}{|c|}{ TABLE VI(b): Estimated amount (tonnes) of mercury in combusted MSW. } \\
\hline Material Removed/diverted (a) & 1989 & 1995 & 2000 \\
\hline None (b) & 97 & 38 & 33 \\
$100 \% \mathrm{~B}$ & & 18 & 14 \\
$100 \% \mathrm{~L}$ & & 33 & 25 \\
$100 \%$ (B $+\mathrm{L}$ ) & 13 & 6 \\
$50 \%$ B & 28 & 24 \\
$50 \% \mathrm{~L}$ & 35 & 29 \\
$50 \%$ (B $+\mathrm{L}$ ) & & 25 & 20 \\
\hline Notes: (a) B = all mercury-zinc batteries, L = all fluorescent lamps; (b) Data derived \\
from information in Tables III-V.
\end{tabular}




\begin{tabular}{|c|c|c|}
\hline \multirow[t]{2}{*}{ TABLE VII: } & \multicolumn{2}{|c|}{$\begin{array}{l}\text { stimated number of units of disposed consumer products that } \\
\text { ogether contain one tonne of mercury. }\end{array}$} \\
\hline & 1989 & 1995 \\
\hline $\begin{array}{l}\text { Alkaline batteries } \\
\text { All mercury-zinc batteries } \\
\text { Button-shaped } \\
\text { Cylinder-shaped } \\
\text { Fluorescent lamps } \\
\text { Fever thermometers } \\
\text { Thermostats }\end{array}$ & $\begin{array}{r}5,800,000 \\
420,000 \\
1,600,000 \\
70,000 \\
18,000,000 \\
1,500,000 \\
355,000\end{array}$ & $\begin{array}{r}\text { ca } 100,000,000 \\
420,000 \\
1,600,000 \\
70,000 \\
18,000,000 \\
1,500,000 \\
355,000\end{array}$ \\
\hline \multicolumn{3}{|c|}{$\begin{array}{l}\text { Notes: Data obtained from analysis of reference [6]. If mercury in fluorescent lamps } \\
\text { were on average reduced to } 27 \text { milligrams per lamp by } 1995 \text { (as cited in (8]), then the } \\
\text { number of lamps that together contain one tonne of merculy would be estimated to be } \\
\text { about } 37 \text { million units. Note mercury content data from reference [6]: button-shaped } \\
\text { batteries (avg. } \mathrm{g}-\mathrm{Hg} \mathrm{O} .629 \mathrm{~g} / \mathrm{battery} \text { ) and cylinder-shaped batteries (avg. } \mathrm{Hg} 14.265 \mathrm{~g}- \\
\mathrm{Hg} / \mathrm{battery} \text {. As before, some rounding off of numbers. }\end{array}$} \\
\hline
\end{tabular}




\begin{tabular}{|c|c|c|c|}
\hline \multirow[t]{3}{*}{ TABLE VIII: } & \multirow{3}{*}{$\begin{array}{l}\text { Handling Cost } \\
\text { (\$U.S.) }\end{array}$} & $\begin{array}{l}\text { I handling cos } \\
\text { ine of mercur }\end{array}$ & n total cost of \\
\hline & & \multicolumn{2}{|c|}{ Total Costs (\$U.S.) } \\
\hline & & 1989 & 1995 \\
\hline Alkaline batteries & $\begin{array}{l}0.01 \\
0.1 \\
1\end{array}$ & $\begin{array}{r}58,000 \\
580,000 \\
5,800,000\end{array}$ & $\begin{array}{r}\text { ca } 1,000,000 \\
\text { ca } 10,000,000 \\
\text { ca } 100,000,000\end{array}$ \\
\hline All mercury-zinc batteries & $\begin{array}{l}0.01 \\
0.1 \\
1\end{array}$ & $\begin{array}{r}4,200 \\
42,000 \\
420,000\end{array}$ & $\begin{array}{r}4,200 \\
42,000 \\
420,000\end{array}$ \\
\hline Button-shaped & $\begin{array}{l}0.01 \\
0.1 \\
1\end{array}$ & $\begin{array}{r}16,000 \\
160,000 \\
1,600,000\end{array}$ & $\begin{array}{r}16,000 \\
160,000 \\
1,600,000\end{array}$ \\
\hline Cylinder-shaped & $\begin{array}{l}0.01 \\
0.1 \\
1\end{array}$ & $\begin{array}{r}700 \\
7,000 \\
70,000\end{array}$ & $\begin{array}{r}700 \\
7,000 \\
70,000\end{array}$ \\
\hline Fluorescent lamps & $\begin{array}{l}0.01 \\
0.1 \\
1\end{array}$ & $\begin{array}{r}180,000 \\
1,800,000 \\
18,000,000\end{array}$ & $\begin{array}{r}180,000 \\
1,800,000 \\
18,000,000\end{array}$ \\
\hline Fever thermometers & $\begin{array}{l}0.01 \\
0.1 \\
1\end{array}$ & $\begin{array}{r}15,000 \\
150,000 \\
1,500,000\end{array}$ & $\begin{array}{r}15,000 \\
150,000 \\
1,500,000\end{array}$ \\
\hline Thermostats & $\begin{array}{l}0.01 \\
0.1 \\
1\end{array}$ & $\begin{array}{r}3,550 \\
35,500 \\
355,000 \\
\end{array}$ & $\begin{array}{r}3,550 \\
35,500 \\
355,000\end{array}$ \\
\hline Notes: Costs may be high & $\begin{array}{l}\text {.. due to lan } \\
\text { Vil. See discl }\end{array}$ & akage. Dat & $\begin{array}{l}\text { d using } \\
\text { itional details }\end{array}$ \\
\hline
\end{tabular}




\begin{tabular}{|l|c|c|c|c|c|}
\hline \multicolumn{5}{|c|}{ TABLE IX(a): Estimated amount (tonnes) of mercury emitted from combusted } \\
MSW (1995) at various levels of air pollution control (APC).
\end{tabular}




\begin{tabular}{|l|c|c|c|c|c|}
\hline \multicolumn{5}{|c|}{ TABLE IX(b): Estimated amount (tonnes) of mercury emitted from combusted } \\
MSW (2000) at various levels of air pollution control (APC).
\end{tabular}




\begin{tabular}{|c|c|c|c|c|c|}
\hline$\%$ APC Control & 0 & 60 & 70 & 80 & 90 \\
\hline \multicolumn{6}{|c|}{$\begin{array}{l}\text { Material } \\
\text { Removed/diverted (a) }\end{array}$} \\
\hline $\begin{array}{l}\text { None } \\
100 \% \text { B } \\
100 \% \text { L } \\
100 \%(B+L) \\
50 \% \text { B } \\
50 \% \text { L } \\
50 \%(B+L)\end{array}$ & $\begin{array}{l}61 \\
81 \\
66 \\
87 \\
71 \\
64 \\
74\end{array}$ & $\begin{array}{l}85 \\
93 \\
87 \\
95 \\
89 \\
86 \\
90\end{array}$ & $\begin{array}{l}89 \\
94 \\
90 \\
96 \\
91 \\
89 \\
92\end{array}$ & $\begin{array}{l}92 \\
96 \\
93 \\
97 \\
94 \\
93 \\
95\end{array}$ & $\begin{array}{l}96 \\
98 \\
97 \\
99 \\
97 \\
96 \\
97\end{array}$ \\
\hline
\end{tabular}




\begin{tabular}{|c|c|c|c|c|c|}
\hline \multicolumn{6}{|c|}{$\begin{array}{l}\text { TABLE IX(d): Estimated percent reduction in mercury emissions in the year } \\
2000 \text { at various levels of air pollution control (APC) compared to } \\
1989 \text { unabated emissions baseline (b). }\end{array}$} \\
\hline$\%$ APC Control & 0 & 60 & 70 & 80 & 90 \\
\hline \multicolumn{6}{|c|}{$\begin{array}{l}\text { Material } \\
\text { Removed/diverted (a) }\end{array}$} \\
\hline $\begin{array}{l}\text { None } \\
100 \% \text { B } \\
100 \% \text { L } \\
100 \%(B+L) \\
50 \% \text { B } \\
50 \% \text { L } \\
50 \%(B+L)\end{array}$ & $\begin{array}{l}66 \\
86 \\
74 \\
94 \\
75 \\
70 \\
79\end{array}$ & $\begin{array}{l}87 \\
94 \\
90 \\
98 \\
90 \\
88 \\
92\end{array}$ & $\begin{array}{l}90 \\
96 \\
92 \\
98+ \\
93 \\
91 \\
94\end{array}$ & $\begin{array}{l}93 \\
97 \\
95 \\
99 \\
95 \\
94 \\
96\end{array}$ & $\begin{array}{l}97 \\
99 \\
97 \\
99+ \\
98 \\
97 \\
98\end{array}$ \\
\hline
\end{tabular}




\begin{tabular}{|c|c|c|c|}
\hline TABLE $X:$ & $\begin{array}{l}\text { Costs estimates for re } \\
\text { levels of mercury in } \\
\text { control technology. }\end{array}$ & $\begin{array}{l}\text { oving one tonne of } \\
N \text { feed using add-on }\end{array}$ & $\begin{array}{l}\text { rcury at various } \\
\text { ctivated carbon }\end{array}$ \\
\hline $\begin{array}{c}\text { Contamination } \\
\text { Level } \\
\text { (g-Hg/tonne MSW) }\end{array}$ & $\begin{array}{l}\text { Tonnes MSW per } \\
\text { tonne of mercury }\end{array}$ & $\begin{array}{l}\text { Nominal cost }(\$) \\
\text { per tonne of MSW } \\
\text { combusted }\end{array}$ & $\begin{array}{c}\text { Total costs }(\$) \text { per } \\
\text { tonne of mercury } \\
\text { removed }\end{array}$ \\
\hline 5 & 200,000 & $\begin{array}{l}0.50 \\
1.00\end{array}$ & $\begin{array}{l}100,000 \\
200,000\end{array}$ \\
\hline 4 & 250,000 & $\begin{array}{l}0.50 \\
1.00\end{array}$ & $\begin{array}{l}125,000 \\
250,000\end{array}$ \\
\hline 3 & 333,000 & $\begin{array}{l}0.50 \\
1.00\end{array}$ & $\begin{array}{l}167,000 \\
333,000\end{array}$ \\
\hline 2 & 500,000 & $\begin{array}{l}0.50 \\
1.00\end{array}$ & $\begin{array}{l}250,000 \\
500,000\end{array}$ \\
\hline 1 & $1,000,000$ & $\begin{array}{l}0.50 \\
1.00\end{array}$ & $\begin{array}{r}500,000 \\
1,000,000\end{array}$ \\
\hline 0.5 & $2,000,000$ & $\begin{array}{l}0.50 \\
1.00\end{array}$ & $\begin{array}{l}1,000,000 \\
2,000,000\end{array}$ \\
\hline
\end{tabular}




\begin{tabular}{|l|c|}
\hline \multicolumn{2}{|c|}{ TABLE XI(a): Amount (g-Hg/tonne ash) of mercury reported found in ash residue } \\
samples at ash disposal sites in the United States.
\end{tabular}




\begin{tabular}{|c|c|}
\hline \multicolumn{2}{|c|}{ TABLE XI(b): Mercury levels (micrograms Hg/liter of leachate) reported found in } \\
leachate collected at the Woodburn ash monofill site, Woodburn, \\
Oregon.
\end{tabular}




\begin{tabular}{|c|c|c|c|c|c|c|}
\hline TABLE XII: & \multicolumn{6}{|c|}{$\begin{array}{l}\text { Estimated concentration (micrograms per cubic meter) of mercury } \\
\text { in exhaust gas of MSW combustor as a function of amount of } \\
\text { mercury ( } g-\mathrm{Hg} / \mathrm{tonne} \mathrm{MSW} \text { ) in MSW feedstock and APC removal } \\
\text { efficiency. }\end{array}$} \\
\hline $\begin{array}{l}\text { \% APC removal } \\
\text { efficiency }\end{array}$ & 0 & 50 & 60 & 70 & 80 & 90 \\
\hline $\begin{array}{l}\text { Mercury in MSW } \\
\text { (g-Hg/tonne MSW) }\end{array}$ & & & & & & \\
\hline $\begin{array}{c}5 \\
4 \\
3 \\
2 \\
1 \\
0.5\end{array}$ & $\begin{array}{c}2300 \\
1800 \\
1400 \\
920 \\
460 \\
230\end{array}$ & $\begin{array}{r}1100 \\
920 \\
690 \\
460 \\
230 \\
110\end{array}$ & $\begin{array}{r}920 \\
730 \\
550 \\
370 \\
180 \\
91\end{array}$ & $\begin{array}{r}690 \\
550 \\
410 \\
280 \\
140 \\
69\end{array}$ & $\begin{array}{r}460 \\
370 \\
280 \\
180 \\
91 \\
46\end{array}$ & $\begin{array}{r}230 \\
180 \\
140 \\
91 \\
46 \\
23\end{array}$ \\
\hline
\end{tabular}


This page intentionally blank.

42 


\section{ANNEX I - ABSTRACTEd LITERATURE}


This page intentionally blank. 


\section{PREFACE}

1. This Annex provides information that supplements and expands upon the Summary Discussion report which precedes this section.

2. Contained herein are abstracted extracts that can be found in publicly available literature. Extracts are referenced to the author(s) of the cited report(s), and where the information in the cited report(s) is not information from a primary source, the secondary sources cited by the report(s) author(s) are indicated.

3. The arrangement of information is as follows: (a) the extract is presented; (b) the attribution to authors of the extracted information is indicated: and (c) the secondary source references are indicated where relevant.

4. The information that has been presented in this Annex is provided in order to:

- expand upon information outlined in the Summary Discussion;

- to provide additional information that is relevant to issues that surround the general problem of management of mercury in the environment;

- to indicate how remarks of various investigators compare in order to provide some composite sense of views of these issues;

- to provide a sense of the extent of knowledge concerning source strengths of mercury; and

- to indicate a sense of the quality of data that is being used to draw conclusions about these issues.

\section{DATA QUALITY, MEASUREMENTS}

5. [p.9]: "The literature is quite confusing regarding mercury emissions from coal-fired power plants. First, it is not always clear whether the measured mercury was total, vapor phase, or that condensed on particulates. Second, the sampling and analytical methods used may have been unreliable."

W. Chow et al., "Managing Air Toxics," Paper No. 90.108.1, Presented at the 83rd Annual Air and Waste Management Association Meeting, Pittsburgh, PA, June 25-29, 1990.

6. [p.52]: "Only a few data are available on the emission sources and fluxes of $\mathrm{Hg}$ [mercury], and the available information is often confusing. For example, no consensus has 
been reached on whether anthropogenic sources contribute more $\mathrm{Hg}$ to the global budget of the metal in air than natural sources."

J.M. Pacyna and J. Munch, "Anthropogenic Mercury Emissions in Europe," Water, Air and Soil Pollution 56:51-63(April 1991).

7. [p.58]: "It is very difficult to assess the accuracy of the above [referring to data stated in the report] presented emissions estimates [re mercuryl. The emission figures for the combustion of fossil fuels seem to be the most reliable, while the estimates for the releases during incineration of wastes are less accurate.

"The most reliable information on emission is available from Central Europe, where national emission inventories are quite advanced. Less information has been compiled from other parts of Europe, and particularly from Southern and Eastern Europe.

"In order to improve the preliminary data base more reliable national information need to be collected. Thus, the preliminary national results should be discussed with national experts.

"There are some additional sources like cement production, battery manufacturing, paint production and application, Cu-mining and smelting, iron and steel industry and crematories which may be important $\mathrm{Hg}$ emission sources in some countries. These sources are not included in the present estimations."

J.M. Pacyna and J. Munch, "Anthropogenic Mercury Emissions in Europe," Water, Air and Soil Pollution 56:51-63(April 1991).

8. [p.135]: [re emission factors for the release of trace metals to the atmosphere] "In most cases, the ranges in the emission factors listed [in a cited table] fall within a factor of 2. 10."

J.O. Nriagu and J.M. Pacyna, "Quantitative assessment of worldwide contamination of air, water and soils by trace metals," Nature 333:134-139(1988).

9. [p.9] The derivation of an inventory of global emissions is hampered by the sparsity of data on the metal contents of raw materials and by uncertainty in the global distribution of sources, especially in developing countries."

J.O. Nriagu, "Global Metal Pollution," Environment 32(7):7-33(1990).

10. [p.26]: "There is, of course, uncertainty associated with the emissions estimates. Nriagu, for example, estimated that 2300 tons [tonnes] of mercury were emitted to the atmosphere as a result of [sic] coal combustion around the globe, with the range of 
uncertainty being $\mathbf{7 0 0}$ to $\mathbf{3 9 0 0}$ tons [tonnes]. However, this uncertainty does not basically alter his assessments of the relative importance of different emission sources."

C. Neme, Electric Utilities and Long-Range Transport of Mercury and Other Toxic Air Pollutants, Center for Clean Air Policy, Washington, DC, November 1991.

11. [p.26]: "Unfortunately, no comprehensive studies of trends in: U.S. mercury emissions, whether from fossil fuel combustion or other sources, are currently available."

C. Neme, Electric Utilities and Long-Range Transport of Mercury and Other Toxic Air Pollutants, Center for Clean Air Policy, Washington, DC, November 1991.

12. [p.31]: "Estimates of the relative importance of man-made and natural emissions sources of mercury are very difficult to make and fraught with uncertainty. A recent estimate by Nriagu suggests that $59 \%$ of global mercury emissions are man-made. EPRI estimates that 30-55\% are man-made."

C. Neme, Electric Utilities and Long-Range Transport of Mercury and Other Toxic Air Pollutants, Center for Clean Air Policy, Washington, DC, November 1991.

J. Nriagu, "A Global Assessment of Natural Sources of Atmospheric Trace Metals," Nature 338(6210), March 2, 1989.

[D] Porcella, "Mercury in the Environment."

13. [p.38]: "Because little attention has been given in the past to utility mercury emissions and little data on the mercury emission reduction potential of various technologies has been collected, all conclusinns should be considered as preliminary."

C. Neme, Electric Utilities and Long-Range Transport of Mercury and Other Toxic Air Pollutants, Center for Clean Air Policy, Washington, DC, November 1991.

14. [p.3]: "The total amount of $\mathrm{Hg}$ [mercury] emitted to the atmosphere is difficult to estimate. Problems encountered are related to meaisirement uncertainties at point sources and to difficulties in estimating diffuse anthropogenic and natural emissions."

B. Hall, P. Schager and O. Lindqvist, "Chemical Reactions of Mercury in Combustion Flue Gases," Water. Air and Soil Pollution 56:3-14(1991).

15. [p.217]: The selective fractionation concentrations [re analysis of $\mathrm{Hg}$ in peat, sediments, etc.] were on the lower end of the linear concentration range for $\mathrm{Hg}$ and analysis 
for $\mathrm{Hg}$ at trace concentrations (nanograms per gram) are always subject to potentially large errors (Huckabee et al., 1979)."

R.T. Di Giulio and E.A. Ryan, "Mercury in Soils, Sediments, and Clams from a North Carolina Peatland, Water. Air and Soil Pollution 33:205-219(1987).

J.W. Huckabee et al., in J.O. Nriagu (ed.) The Biogeochemistry of Mercury in the Environment, Elsevier, Amsterdam, pp.277-302(1979).

16. [p.3]: "...the potential for inaccuracies when using Method 101A [for the sampling and analysis of mercury emissions at MWC facilities] after ammonia-injection devices, the EPA does not feel that the low levels of ammonia that will typically enter the emission stream will create inaccuracies in measuring the much higher concentrations of mercury that will be present. The absorbing reagent used in the method has the capacity to easily collect such levels of ammonia as well as native or reacted mercury in both the elemental and oxidized states. However, bench-scale work is now being conducted to evaluate this effect.

"Based on the above, the EPA considers Method 101A to be an appropriate method for measuring mercury emissions from MWC's. However, we will continue to evaluate Method $101 \mathrm{~A}$ in order to expand our data base and validate the conclusions above."

M.G. Johnston, [Memorandum] "Mercury Testing at Municipal Waste Combustors," EPA, Research Triangle Park, May 18, 1990.

17. [p.3]: [Asked if EPA was confident with the test (Method 101A) results, considering controversies surrounding the test methods] "[An EPA representative] stated that minor changes to Method 101 $\mathrm{A}$ ar $\forall$ being incorporated and that the labs have been alerted to these changes. These revisions to the method will ensure confidence in the method. ... IEPA representative] also noted that analyses are being conducted to validate the draft multi-metals method.

"[Asked whether EPA would be requiring labs to qualify to do the analyses] [An EPA representative] said no. He said they believed that some of the work that showed differing results over time can be attributed to precipitate in the sampling filter. The changes in the Method 101A test method will resolve this problem by specifying allowable sample storage time or by accounting for any $\mathrm{Hg}$ in the precipitate. [EPA representative] said EPA now has a great deal of confidence in the revised method."

EPA, Meeting Summary of September 6, 1991 briefing, September, 6, 1991, EPA, Washington, DC.

18. [p.10-29]: [Analyses of tests conducted at the Burnaby, British Columbia incinerator] "When the MM [multimetals] and 101 A [Method 101 A] trains are compared, the RSD [residual standard deviation] is 96 and the median bias is 100 micrograms per dry standard cubic 
meter. Radian Corporation recently completed parallel testing of 101A and MM against themselves and each other. The RSDs were 65 and 50 micrograms per dry standard cubic meter at $11 \%$ oxygen, respectively. The bias was -50 micrograms per dry standard cubic meter at $11 \%$ oxygen. The Radian test used parallel probes (two sampling trains strapped together) as opposed to traversing trains on perpendicular tracks employed at Burnaby. The Radian RSD is smaller than found at Burnaby, but the result is comparable given the relative number of data points employed. The bias found by Radian, however, is half that found in the Burnaby project and of the opposite sign.

"These results indicate significant precision and bias problems both within and between the methods. Method development is indicated."

[G. Rigo, personal communication to W.M. Shaub, based on Progress Print] "Waste Analysis, Sampling, Testing and Evaluation (Waste Program): Effect of Waste Stream Characteristics on MSW Incineration: The Fate and Behavior of Metals," Progress Print re Mass Burn MSW Incineration tests at Burnaby BC, Volume II, February 1992.

19. [p.10-30]: [re Sodium Sulfide injection tests at the Burnaby, BC incinerator] "Median mercury removal efficiency with the sodium sulfide treatment system in use was 71 percent. Recent Radian Corporation research for Ogden-Martin systems of Stanislaus, Inc. into the behavior of Method 101A when testing sodium sulfide treated flue gas strearins indicates that the median removal efficiency may be overstated by 30 percent due to significant mercury retention on the laboratory filter when sodium sulfide is in use. The lab filter mercury retention was small when sodium sulfide injection is not used.

"Without the sodium sulfide treatment system in use, the measured efficiency was 91 percent! As noted previously, the conditions for this test are suspect. The plant had a dry lime reactor and fabric filter ash system failure and the mode of operation was changed. The lime used may have contained activated carbon. If it did, this efficiency is not indicative of DSI/FF performance, rather it is indicative of activated carbon mercury control."

[G. Rigo, personal communication to W.M. Shaub, based on Progress Print] "Waste Analysis, Sampling, Testing and Evaluation (Waste Program): Effect of Waste Stream Characteristics on MSW Incineration: The Fate and Behavior of Metals," Progress Print re Mass Burn MSW Incineration tests at Burnaby BC, Volume II, February 1992.

20. [p.179]: "In the Bamberg garbage incinerator, which is equipped with acid wet scrubbing, 0.85 cubic meters of water is required per ton[ne] of garbage. Long term investigation during the years 1978 to 1983 found on the average 4 milligrams $\mathrm{Hg}$ per liter in the scrub water. This means a content of 3.5 grams $\mathrm{Hg}$ per tonine] of garbage in the exhaust behind the electrofilters. If the mercury concentration of about $20 \mathrm{ppm}$ in the fly ash is added, about 4 grams $\mathrm{Hg}$ per ton[ne] of garbage must be transported in the raw gas. Similar values have also been reported from Swiss incinerators. 
"Far less conclusive are published works concerning mercury emissions from incinerators with dry purification. Although they report clean-gas emissions of less than or equal to 50 micrograms per normal cubic meter, the mercury balance, if given at all, is only 1 to 2 grams and should be considered as a reason for checking the reliability of the analysis. The determination of mercury is among the most difficult of inorganic analyses because of its volatility, e.g., in sample digestion and also in the storage of samples. Several independent methods of analysis are indicated here."

H. Vogg, "Behavior of (heavy) metals in the incineration of municipal wastes," International Chemical Engineering 27(2):177-182(April 1987), and Chemie-InqenieurTechnik 56(10):740-744(1984)

P.H. Brunner and J. Zobrist, Mull Jundl Abfall 15:221 (1983).

W. Schlottmann, VGB Kraftwerkstechnik 62:956(1982).

D.O. Reimann, "Purification of Flue Gas Scrubbing Waters in the Bamberg Garbage Thermal Power Plant with Emphasis on the Elimination of Mercury by the Addition of TMT.15," VGB Fachtagung Mullverbrenung, Regensburg, November 11 (1983).

Chr. Marnet, B. Kassebohm and J. Bewerunge, "Quasi-dry purification of exhaust from the Dusseldorf garbage incineration plant and heavy metal elimination," Waste Technology Colloquium, Institute for Municipal Water System Construction, Water Quality and Waste Industry of the University of Stuttgart-Busnau (1983).

K.-D. Pfeiffer, "Flue gas purification by the Flakt-DAS process in garbage incineration plants," Fachtagung Mullverbrennung und Rauchqasreinigung (K.J. Thome-Kozmiensky, Ed.), E. Freitag, Verlag fur Umweittechnik, Berlin (1983).

\section{NATURAL SOURCES}

\section{A. Atmospheric background levels}

21. [Appendix 15, p.3]: "The background levels utilized by the U.S. EPA in their health assessment of mercury are: 1) background levels in the troposphere of the Northern Hemisphere are estimated at 2 nanograms per cubic meter; and 2) urban air may have an average concentration of up to 10 nanograms per cubic meter."

A.H. Smith et al., Health Risk Assessment for the Brooklyn Navy Yard Resource Recovery Facility, Volume "1, November 1988.

OHEA, U.S. EPA, "Mercury Health Effects Update: Health Issue Assessment, Report \# EPA-600/8-84-019F, August 1984. 


\section{B. Peat soils}

22. [p.205]: "Total $\mathrm{Hg}$ concentrations in peat cores ranged from 40 to 193 nanograms per gram (dry weight); no depth related trends were noted.

"...North Carolina's coastal wetlands comprise approximately 2.6 million square kilometers of peatlands containing an estimated $\mathbf{5 4 0}$ million tonne[s] of harvestable peat (Ingram and Otte, 1981).

"Research in peatlands in Minnesota (Clausen et al., 1980) and Finland (Simola and Lodenius, 1982) implicated drainage from peatlands as a source of elevated $\mathrm{Hg}$ concentrations in receiving waters. In addition, the high affinity and adsorption capacity of peat for $\mathrm{Hg}$ suggests that atmospheric inputs of $\mathrm{Hg}$ to developing peat deposits would be strongly bound and therefore accumulate with the peat (Madsen, 1981). Mining of peat could expose the anaerobically preserved peat to oxidizing conditions with the possibility that the associated $\mathrm{Hg}$ accumulated over thousands of years, could be rapidly mobilized into adjoining surface waters."

R.T. Di Giulio and E.A. Ryan, "Mercury in Soils, Sediments, and Clams from a North Carolina Peatland, Water, Air and Soil Pollution 33:205-219(1987).

R.L. Ingram and L.J. Otte, Peat Deposits of Croatan Forest, Craven, Janes, and Carteret Counties, North Carolina Report to the U.S. DOE, Washington, DC and North Carolina Energy Institute, Raleigh (1981).

Clausen et al., Proceedings of the 6th International Peat Congress, Duluth, MN, pp.533-537 (1980).

H. Simola and M. Lodenius, Bull. Environ. Contam. Toxicol. 29:298(1982).

P.P. Madsen, Nature 293:127(1981).

23. [p.12]: "High mercury concentrations have been documented in peat and organic soils of Scandinavia and elsewhere which may contribute to increased introduction of mercury into the aquatic food chain."

[Annex] "Mercury in Fish and Wildlife Task Force: A Work Plan to Guide Multi-Agency Efforts to Define and Understand Mercury Accumulation in Florida Fisheries," In: Florida State University, Proceedings of Workshop on Mercury Contamination in Florida: Impacts and Solutions, Florida State Conference Center, Tallahassee, Florida, June 20-21, 1990.

24. [p.132]: "It could not be concluded by the work group after discussing the available information whether mercury primarily originates from the peat or from atmospheric 
deposition, or whether the primary sources of mercury concentration are from natural or anthropogenic sources."

F. Ware and G. Henderson, "Mercury in Aquatic Biota Work Group," In: Florida State University, Proceedings of Workshop on Mercury Contamination in Florida: Impacts and Solutions, Florida State Conference Center, Tallahassee, Florida, June 20-21, 1990.

25. [p.11]: "There is evidence that supports the hypothesis that there is a positive relationship between the presence of peat soils, low pH water and the expression of mercury in Florida's aquatic environment."

V. Lambou, "Organization and Overview," In: Florida State University, Proceedings of Workshop on Mercury Contamination in Florida: Impacts and Solutions, Florida State Conference Center, Tallahassee, Florida, June 20-21, 1990.

26. [p.13]: "One of the unexpected aspects of this problem Imercury contamination in Floridal is that there have been high levels of mercury found in the Everglades. We have only recently identified the elevated mercury levels in the Everglades because that was one of the last places that we expected to find mercury contamination. The Everglades are relatively distant from major urban or industrialized areas and, as such, there are no obvious pointsources discharges of mercury to the Everglades."

T. Atkeson, "History and Background: Mercury Contamination in Florida," In: Florida State University, Proceedings of Workshop on Mercury Contamination in Florida: Impacts and Solutions, Florida State Conference Center, Tallahassee, Florida, June 20$21,1990$.

27. [p.3]: "While no research has yet been conducted in Florida to verify this hypothesis [that significant mercury in the environment may be available from process that disturb peat soils, e.g. . burning, slow oxidation, drainage, etc.], work performed in Finland, a country with one third of its land covered in peat soil, has traced mercury contamination to various types of disturbance of that soil."

U.S. Fish \& Wildlife Service, Status Report on Mercury Contamination in Florida Panthers, Prepared for the Florida Panther Interagency Committee (1989)

28. [p.59]: "The last point I want to make is that one possible explanation for the increase in mercury bioavailability in peat areas is that mercury is released from insoluble organic matter complexes to smaller molecular weight forms. Thus it is more mobile in the form of more bioavailable complexes after drainage and subsequent oxidation of the peat. In the Florida Everglades, approximately one inch of peat is oxidized each year when it is used for agricultural purposes. This oxidation process releases the mercury in association with smaller 
molecular weight forms rather thain] the large insoluble organic matter. This may be related to its increased mobility, and perhaps, its increased bioavailability."

W. Patrick, "Soil Redox Processes: Bioavailability of Mercury," In: "Florida State University, Proceedings of Workshop on Mercury Contamination in Florida: Impacts and Solutions, Florida State Conference Center, Tallahassee, Florida, June 20-21, 1990.

29. [p.215]: "No methyl $\mathrm{Hg}$ concentrations above the detection limit of 25 nanograms per gram (dry weight in peat and sediment samples, wet weight in R. cuneata) were detected in any samples.

"...Furthermore, only a small percent of total $\mathrm{Hg}$ apparently exists as methyl $\mathrm{Hg}$ in sediments."

R.T. Di Giulio and E.A. Ryan, "Mercury in Soils, Sediments, and Clams from a North Carolina Peatland, Water, Air and Soil Pollution 33:205-219(1987).

30. [pp.4-5]: "Simons (1989) noted that the South Florida Water Management District found mercury concentrations in peat ranging from 0.1 to $0.3 \mathrm{ppm}$. Assuming (1) that on the average, 1.12 inches of peat is lost to oxidation annually, (2) that the average mercury content of peat is $0.2 \mathrm{ppm},(3)$ that oxidation occurs uniformly over the approximately 430,000 acres of peat soils in south Florida, and (4) that methylation of mercury is occurring in peat as a result of natural biological activity associated with oxidation, then approximately 8.2 tons of methyl mercury could be released from peat deposits annually (Simons 1991)."

M.E. Roelke, D.P. Schultz, C.F. Facemire, S.F. Sundlof and H.E. Royals, Mercury Contamination in Florida Panthers, A report of the Florida Panther Technical Subcommittee to the Florida Panther Interagency Committee (December 1991).

J.N. Simmons, "Mercury in the Everglades: What is the role of Agriculture?" Florida Nat. Spring 1991, pp.7-9.

INote: Using the data from the above reference, li.e., 430,000 acres of peat soil; $0.2 \mathrm{ppm}$ mercury content; 1.12 inches of peat loss annually due to slow oxidation] and using a reference density for peat soil of $0.84 \mathrm{grams}$ per cubic centimeter (Handbook), it is calculated that mercury loss from peat soils would amount to an annual release of $\mathbf{8 . 2}$ metric tonnes [about 9 tons or about 18,000 pounds] of mercury. Thus in the above reference figures, a peat density of about 0.84 grams per cubic centimeter must have been used. The assumption that it all appears as methyl mercury reasonable does not seem reasonable; $\theta . g .$, refer to other citations, this annex.]

Per the above Note, data re peat density is taken from...

R.C. Weast, Editor-In-Chief, Handbook of Chemistry and Physics, (47th Edition) 1966, p. F-1, The Chemical Rubber Co., Cleveland.] 
31. [p.3]: "The $\mathrm{Hg}$ [mercury] content in coal and peat usually varies from 0.02 to 1 microgram/gram, but can be as high as 3 micrograms/gram."

B. Hall, P. Schager and O. Lindqvist, "Chemical Reactions of Mercury in Combustion Flue Gases," Water. Air and Soil Pollution 56:3-14(1991).

S. Mitra, "Hg in the Ecosystem," ISBN 0-87849-529-0, Trans. Tech. Publications Ltd. Switzerland 1-327 (1986).

32. [p.6]: "Mechanism for movement of mercury through the aquatic environment in Florida are unknown. The most popular hypothesis identifies peat which may act either as a mercury sponge for atmospheric deposition or contain a natural geologic burden. Contact with acidic water allows for the mobilization of mercury into aquatic systems. Microbes biosynthesize the inorganic form into the methylated form (toxic organic), where it can move up the food chain through biomagnification, producing elevated levels in top predators, e.g., largemouth bass, bowfin, Florida gar.

"If the peat hypothesis proves valid, this will explain the extremely high values found in Conservation Area III la management region in Florida], which receives substantial run-off from agricultural peat farms immediately upstream. Farming practices of tilling and burning peat soils may facilitate mercury mobilization through direct contact with acid rain or vaporization, producing elevated downstream levels found in top predators of the Conservation Area."

F. Ware, H. Royals and T. Lange, "Mercury Contamination in Wildlife," Florida Game and Fresh Water Fish Commission, Tallahassee, Florida, Draft received February 1992.

\section{Soils and sediments}

33. [p.47]: "There are wide variations in mercury levels found in soils. The USGS has found the average soil concentration of mercury to be approximately $100 \mathrm{ppb}$. From personal experience, I estimate that $10-60 \mathrm{ppb}$ is a representative range of values for top soil."

P. Krenkel, "Mercury in the Environment: Methylation and Sediment Reactions," In: "Florida State University, Proceedings of Workshop on Mercury Contamination in Florida: Impacts and Solutions, Florida State Conference Center, Tallahassee, Florida, June 20-21, 1990.) 
34. [p. 3]: "The percentage of methyl mercury lin sediments] is generally thought to be less than $1 \%$ of the total mercury."

V. Lambou, "Organization and Overview, In: "Florida State University, Proceedings of Workshop on Mercury Contamination in Florida: Impacts and Solutions, Florida State Conference Center, Tallahassee, Florida, June 20-21, 1990.

35. [p. 33]: [re analysis some period of time after a site contamination incident due to a large release of elemental mercury and mercuric nitrate from 1958 to 1962] "We found that in 1986 and 1987 , approximately $90 \%$ of the total mercury present at the site was in the form of mercuric sulfide, 10 to $15 \%$ occurred as elemental mercury, and less than $1 \%$ occurred as methyl mercury."

N. Revis, "Mercury Speciation: Impacts on Aquatic Toxicity," In: "Florida State University, Proceedings of Workshop on Mercury Contamination in Florida: Impacts and Solutions, Florida State Conference Center, Tallahassee, Florida, June 20-21, 1990.

36. [p.65]: "We have not been able to find any significant correlation between mercury concentrations in sediments and any other sediment parameter."

S. Schropp, "Mercury Levels in Florida Sediments," In: "Florida State University, Proceedings of Workshop on Mercury Contamination in Florida: Impacts and Solutions, Florida State Conference Center, Tallahassee, Florida, June 20-21, 1990.\}

37. [Unpaginated Abstract] [symbols reproduced as they appear in the abstract] "The behavior of $\mathrm{Hg}$ in the soil is mainly controlled by adsorption and desorption processes depending on complexation, the most important ligands in solution being $\mathrm{OH}^{*}$ * minus, $\mathrm{Cl}^{*}$ * minus, and organic anions. Since the solubility of $\mathrm{HgCl} / / 2$ and $\mathrm{Hg}(\mathrm{OG}) / / 2$ is rather high, the affinity of $\mathrm{Hg}$ to these ligands leads to an increased mobility. This is especially true for $\mathrm{HgCl} / 2$, whereas the hydrolysis of $\mathrm{Hg} *$ * $^{*}$ * plus may result in the specific adsorption of $\mathrm{Hg}$ on mineral colloids. The high affinity of $\mathrm{Hg}$ to $\mathrm{S}$ explains the strong binding of $\mathrm{Hg}$ to soil organic matter and also the stability of $\mathrm{HgS}$. Further precipitation products than $\mathrm{HgS}$ are unlikely to occur, since the activity of $\mathrm{Hg}^{*}$ " 2 * " plus remains too low to exceed the solubility product of any other defined $\mathrm{Hg}$ compound. It is mainly the physical fractioning of soil organic matter (dissolved vs adsorbed) that determines the behavior and distribution of $\mathrm{Hg}$ in soils."

E. Schuster, "Behavior of mercury in the soil with a special emphasis on complexation and adsorption processes. A review of the literature," in E.l. Monthly No: ElM9201001434 from International Conference on Mercury as an Environmental Pollutant, Gavle, Sweden, June 11-13, 1990. 


\section{Sugar cane}

38. [p.4]: "Simons (1991) estimated that over ten tons of mercury could be released into the atmosphere annually from burning and processing sugar cane if mercury concentrations in sugar cane average $0.5 \mathrm{ppm}$. However this figure was based only on mercury content of the cane (0.03 to $1.2 \mathrm{ppm})$, and did not consider the possibility of mercury on the external surface of the cane as a result of atmospheric deposition. The residence time for atmospheric mercury, of which some 25 to 30 percent is of anthropogenic origin, has been estimated by Clarkson et. al. (1984) to be somewhere between 6 and 90 days."

J.N. Simmons, "Mercury in the Everglades: What is the role of Agriculture?" Elorida Nat. Spring 1991, pp.7-9.

T.W. Clarkson, R. Hamada and L. Amin-Zaki, "Changing Metal Cycles and Human Health," pp.285-309; In: Mercury, J.O. Nriagu, Ed., Springer-Verlag, Berlin.

\section{ANTHROPOGENIC EMISSIONS OF MERCURY}

39. [p.198]: "FLORIDA - A waste-to-energy industry trade group hopes it is not the sole target of standards governing mercury emissions being developed by the Florida Department of Environmental Protection. During an April public workshop, Jeffrey Hahn of Ogden Martin Systems, Inc., representing the Integrated Waste Services Association, told the department that his industry will help develop the standards, but encouraged officials to consider other emission sources, such as fossil fuel power plants, various chemical and industrial processes, landfills and agricultural processes."

(Editorial staff), Solid Waste Report, May 18, 1992.

\section{A. The Minimata incident}

40. [pp.21-22]: "The Minimata and the Niagata incidents are the two notorious Japanese tragedies. All the other incidents [of human exposure] involve the use of methyl mercury as a fungicide. With the exception of Japan, the incidents have all occurred in nonindustrialized countries. They are all associated with agriculture in rural areas. Methyl mercury was used as a fungicide for a long time in Canada and in Western Europe, and in Sweden. The U.S. has virtually no cases of poisoning. If used as a fungicide on seed and the seed wheat is planted, then the harvested crop is essentially harmless. What happened in these incidents lin nonindustrialized countries] was that the treated grain, instead of being planted, was used directly to make bread.

"Let us start with the Minimata incident in Japan. Mercury was discharged as an effluent from a factory into this bay. One of the most remarkable things about the Minimata incident 
is that the mercury was discharged into a fairly substantial ocean bay and was bioaccumulated to the extent that it killed the people who ate the fish. I do not know of any other situation where this has ever happened. The degree of bioaccumulation was enormous since the people eating the fish were actually receiving a fatal dose. The second point to keep in mind is that methyl mercury itself was released. Although other forms of mercury were also released, such as inorganic mercury, methyl mercury was discharged into the ocean bay. The third point which is common to the other incidents, is that the people who were poisoned, who consumed the fish, were fishermen and their families. They were dependant on fish as a major protein source. If these people would have had a mixed diet, the outbreak may not have occurred or would have been much less intense."

T. Clarkson, "Health Consequences: Mercury in the Environment," In: Florida State University, Proceedings of Workshoo on Mercury Contamination in Florida: Impacts and Solutions, Florida State Conference Center, Tallahassee, Florida, June 20-21, 1990.

\section{B. Mercury contamination in Florida}

[Note: see also the discussion re peat soils above]

41. [p.29]: "However, the greatest problem facing Florida appears to be the fact that sources of mercury in your state are of a non-point source nature. This aspect of the Florida [mercury contamination] problem will make it relatively more difficult to manage."

J. Hesse, "The Human Population: Receptor for Aquatic Contaminants," In: Florida State University, Proceedings of Workshop on Mercury Contamination in Florida: Impacts and Solutions, Florida State Conference Center, Tallahassee, Florida, June 2021, 1990.

42. [p.113]: "Most of the mercury found in St. Andrew Bay is in Watson Bayou near the paper mill and is believed to be associated with earlier paper mill operations, several marine repair yards, and a sewage treatment plant. Sediment values were measured as high as 1.5 ppm mercury. The highest value was found on an arm of Watson Bayou directly behind the paper mill. Additional samples have been collected, and it is believed that there is a very strong correlation between the presence of mercury and the discharges from the paper mill which once used phenyl mercuric acetate as a slimacide. While use of phenyl mercuric acetate was discontinued many years ago, this historical problem has affected the entire bayou. Other distinct areas of elevated concentrations were found near a marine railway operation."

M. Brim, "U.S. Fish and Wildlife Service Environmental Contaminants Program," In: Florida State University, Proceedings of Workshoo on Mercury Contamination in Florida: Impacts and Solutions, Florida State Conference Center, Tallahassee, Florida, June 20-21, 1990. 


\section{Alobal inouts of mercury to the environment}

43. [p.55]: "A total emission of about 400 tltonnes]/year was estimated for Europe [in 1982], with fossil fuel combustion as a dominating source (about $69 \%$ ), chlorine production emitted about $18 \%$, waste incineration about $7 \%$ and at least non[-]ferrous metal industry about $6 \%$ of total mercury emission in Europe in 1982."

J.M. Pacyna and J. Munch, "Anthropogenic Mercury Emissions in Europe," Water. Air and Soil Pollution, 56:51-63(April 1991).

44. [p. 35] "The current understanding is that mercury emissions to the atmosphere cycle globally. The best estimates are that the amount of mercury in the atmosphere is close to 6 billion grams [6000 tonnes] and the mean residence time of mercury in the atmosphere is about one year (Fitzgerald, 1989). Current estimates suggest that anthropogenic sources contribute approximately $30-55 \%$ [see note re Fossil fuels section below re estimate of 2260 tonnes due to coal] of the total input into the atmosphere (Fitzgerald, 1989; Nriagu and Pacyna, 1988). Fossil fuel burning accounts for slightly more than half of the annual anthropogenic input. Roughly, two-thirds of the cumulative anthropogenic input has occurred since the beginning of the twentieth century. U.S. fossil fuel burning contributes approximately $5 \%$ to the total amount of mercury found in the atmosphere."

[Note: If $\mathbf{5 \%}$ of the total [6000 tonnes] mercury found in the atmospher $?$ is attributed to emissions from fossil fuel burning in the United States, this would correspond to an annual emissions release of mercury of $\mathbf{3 0 0}$ tonnes from U.S. fossil fuel burning.]

N. Revis, "Mercury Speciation: Impacts on Aquatic Toxicity," In: "Florida State University, Proceedings of Workshop on Mercury Contamination in Florida: Impacts and Solutions, Florida State Conference Center, Tallahassee, Florida, June 20-21, 1990.

W.F. Fitzgerald, Chapter 57: "Atmospheric and Oceanic Cycling of Mercury," In: Chemical Oceanography Volume 10, Academic Press, New York (1989).

J.O. Nriagu and J.M. Pacyna, "Quantitative Assessment of Worldwide Contamination of Air Water and Soils by Trace Metals," Nature 333:134-139(1988).

45. [p.23 - Table 2-2 - "Electric Utility Emissions of Selected Trace Metals in 1987 as Estimated by the Center for Clean Air Policy"]: Mercury Emissions (1987) $=81$ (short) tons

C. Neme, Electric Utilities and Long-Range Transport of Mercury and Other Toxic Air Pollutants, Center for Clean Air Policy, Washington, DC, November 1991.

46. [p.5]: "Man-made sources, for example, account for approximately $60 \%$ of global mercury air emissions, according to a recent estimate by Dr. Jerome Nriagu of the Canadian 
National Water Research Institute. Moreover, much of what is now called 'natural' emissions may actually be re-emissions of pollutants previously deposited in the environment by human activity."

C. Neme, Electric Utilities and Long-Range Transport of Mercury and Other Toxic Air Pollutants, Center for Clean Air Policy, Washington, DC, November 1991.

J. Nriagu, "A Global Assessment of Natural Sources of Atmospheric Trace Metals," Nature 338, No. 6210, March 2, 1989.

47. [p.78]: "The residence time for mercury in the atmosphere ranges from several days to severz I months." [compare with above citation]

C. Watkins, "Atmospheric Deposition and Mercury Accumulation in Fish," In: "Florida State University, Proceedings of Workshop on Mercury Contamination in Florida: Impacts and Solutions, Florida State Conference Center, Tallahassee, Florida, June 2021, 1990.

\section{Chlor-alkali facilities}

48. [p.55]: "Three types of electrolytic cells are used to produce $\mathrm{Cl}$ [chlorine], and caustic soda: the $\mathrm{Hg}$ [mercury] cell, the diaphragm cell, and the membrane cell. Mercury is emitted to the atmosphere only from the $\mathrm{Hg}$-cell process.

"The European countries report wide range of emission factors for their chlor-alkali plants from $<0.5 \mathrm{~g}$ [grams] to $7.0 \mathrm{~g} \mathrm{Hg} / \mathrm{t}$ [tonne] production capacity. A factor of $5.2 \mathrm{~g} \mathrm{Hg} / \mathrm{t}$ production capacity was used in this survey.

"Mercury emissions from chlor-alkali plants were assumed to consist mostly of $\mathrm{Hg}$ vapor as elemental (metallic) $\mathrm{Hg}$ and bivalent $\mathrm{Hg}(\mathrm{Hg} / \mathrm{as} \mathrm{HgCl}$ )."

J.M. Pacyna and J. Munch, "Anthropogenic Mercury Emissions in Europe," Water, Air and Soil Pollution 56:51-63(April 1991).

49. [p. 27] "In Sarnia (Canada) there were two chlor-alkali facilities discharging elemental mercury at a rate of about 50 to 100 pounds per day into the St. Clair River." [16.5 tonnes per year]

J. Hesse and H. Humphrey, "The Human Population: Receptor for Aquatic Contaminants," In: "Florida State University, Proceedings of W kshoo on Mercury Contamination in Florida: Impacts and Solutions, Florida State Conference Center, Tallahassee, Florida, June 20-21, 1990. 
50. [p. 105]: "Our experiences with mercury contamination include a chloralkali plant that began discharging into a river in 1967. The flow from this plant was approximately 200,000 cubic feet of water a second. The flow represents the equivalent of approximately 200 pounds of mercury a day." [33 tonnes per year]

A. Johnson, "Monitoring of Mercury in Fish," In: "Florida State University, Proceedings of Workshoo on Mercury Contamination in Florida: Impacts and Solutions, Florida State Conference Center, Tallahassee, Florida, June 20-21, 1990.\}

\section{E. Mercury emission from non-ferrous metal oroduction}

51. [p.55]: "High temperature processes in non-ferrous metal production emit large amounts of $\mathrm{As}, \mathrm{Cd}, \mathrm{Cu}, \mathrm{In}, \mathrm{Pb}$ and $\mathrm{Zn}$. Most base metal sulfide ores contain also some $\mathrm{Hg}$ [mercury]. The amount is usually very small. Lead and $\mathrm{Zn}$ ores generally have a higher $\mathrm{Hg}$ content than ores of other base metals. Thus the $\mathrm{Hg}$ emissions from the production of $\mathrm{Pb}$ and $\mathrm{Zn}$ are of special interest.

"Virtually all the $\mathrm{Hg}$ in a smelter feed volatilizes and enters the gas stream. Roughly a half of the gaseous $\mathrm{Hg}$, mostly in a metallic form, is retained in the weak acid scrubber and almost the rest in the product acid in an acid plant of a smelter complex. Small amounts of $\mathrm{Hg}$ are however, emitted to the atmosphere."

J.M. Pacyna and J. Munch, "Anthropogenic Mercury Emissions in Europo," Water, Air and Soil Pollution 56:51-63(April 1991).

\section{F. Fluorescent lamos}

52. [p.7]: "The second highest source of mercury in MSW in 1989 was estimated to be electric lighting. This mercury came from two sources [ordinary fluorescent lamps and (certain) high intensity lamps].

"... Of these two sources, fluorescent lamps are by far the largest, accounting for 33 tons of mercury in MSW in 1989, or 4.6 percent of total discards.

"FINAL DRAFT DELIVERABLE, "Characterization of Products Containing Mercury in MSW in the U.S. 1970 - 2000," A.T. Kearney and Franklin Assoc., Inc. . IEPA Contract No. 68-W9-0040] January 1991.

53. [p.71]: "...the targeted toxic material is mercury, which every fluorescent lamp contains in small quantities.

"...More than 500 million fluorescent lamps are discarded in the U.S. each year. 
"...Three companies in California say they currently process a total of more than 600,000 fluorescent lamps a month for recycling. Most of these tubes come from commercial, industrial and institutional buildings.

"...Under pressure from the fluorescent lamp manufacturing industry to come up with a management policy for spent lamps, the U.S. Environmental Protection Agency is leaning toward issuing regulations that would require recycling of the lamps."

T. Watson, "Fluorescent lamps - a bright new recyclable," Resource Recycling (March 1992).

54. [p.74]: "[re Marin County, CA] ...A total of 434 fluorescent tubes were collected from residents ...Mercury Technologies Corp., a Northern California fluorescent lamp processor, handled the lamps for Marin County at a total cost of $\$ 303$, including transportation..."

T. Watson, "Fluorescent lamps - a bright new recyclable," Resource Recycling (March 1992).

55. [p.76]: "[re California recyclers] All three of the lamp processors charge about 10 cents per foot of tube length to accept fluorescent lamps."

T. Watson, "Fluorescent lamps - a bright new recyclable," Resource Recycling (March 1992).

56. [p.77]: "...more than 50 million fluorescent lamps are already collected in Europe each year..."

T. Watson, "Fluorescent lamps - a bright new recyclable," Resource Recycling (March 1992).

57. [p.78]: "In Minnesota - which has a high incineration rate - legislators are considering a bill that would ban disposal of fluorescent lamps and other items that contain mercury. ....No fluorescent lamp processing operations exist in the state."

T. Watson, "Fluorescent lamps - a bright new recyclable," Resource Recycling (March 1992).

\section{G. Fever thermometers}

58. [p.8]: "Mercury is used in a wide variety of instruments, but most of these were identified to be used in industrial applications. The familiar fever thermometer was, however, 
identified as a source of mercury discarded from homes and medical establishments. In 1989, an estimated 16.3 tons of mercury were discarded in thermometers, or just over 2 percent of total discards.

"Mercury fever thermometers are being replaced by digital thermometers, especially in medical applications. It therefore was projected that there will be a gradual decline in discards of mercury from this source."

"FINAL DRAFT DELIVERABLE, "Characterization of Products Containing Mercury in MSW in the U.S. 1970 - 2000," A.T. Kearney and Franklin Assoc., Inc., IEPA Contract No. 68-W9-0040] January 1991.

\section{H. Thermostats}

59. [p.8]: "The typical thermostat used for temperature control in residences and other buildings contains mercury that could enter MSW if the thermostat is discarded. (This mercury could also become demolition waste if the thermostat is in a demolished house.) An estimated 11 tons of mercury entered MSW in thermostats in 1989; this was less than 2 percent of total discards.

"Thermostats have a long life - estimated to be 20 years - so there is a long lag time before they are discarded. (Note that the apparent dip in discards of mercury in thermostats in 1995 is due to low housing starts in the recession year of 1975.) Thus, even though mercury thermostats are gradually being replaced by digital thermostats, they are projected to continue to be a source of mercury in MSW through 2000."

"FINAL DRAFT DELIVERABLE, "Characterization of Products Containing Mercury in MSW in the U.S. 1970 - 2000," A.T. Kearney and Franklin Assoc., Inc., IEPA Contract No. 68-W9-0040] January 1991.

\section{Dental uses/amalgams}

60. [0.9]: "Mercury is used in dental amalgams for fillings in teeth. Most mercury in dentist's offices is collected for re-refining, but some is discarded, and a small amount of mercury is assumed to enter MSW in lost teeth and fillings. It was estimated that 4 tons of mercury (less than one percent of total discards) entered MSW from these sources in 1989."

"FINAL DRAFT DELIVERABLE, "Characterization of Products Containing Mercury in MSW in the U.S. 1970 - 2000," A.T. Kearney and Franklin Assoc., Inc., IEPA Contract No. 68-W9-0040] January 1991. 
61. [p.42]: "In a survey of dental offices where mercury is used as an amalgam for fillings, average values of $\mathbf{2 5}$ micrograms per cubic meter have been obtained."

A.H. Smith et al., "Health Risk Assessment for the Brooklyn Navy Yard RR Facility," Final Report, Volume 1: Text, November 1988.

\section{J. Aluminum production}

62. [p.2412]: "In the suit, the attorney general will allege that ALCOA's Point Comfort, Texas plant discharged mercury into the bay starting in the 1960's at levels as high as 67 pounds per day."

(Editorial staff). "Texas Tells ALCOA it Will File Suit Over Mercury Contamination in Lavaca Bay," Environmental Reporter, February 21, 1992.

\section{K. Mercury in landfills}

63. [p.1]: There have also been concerns raised about the reaction of zinc carbon batteries with alkaline batteries during mixed storage, and the emission of $\mathrm{Hg}$ gas from landfills (Sweden)."

S.J. Levy, "European Battery Management Practices," Presented to OAQPS "Precombustion Control of Mercury Emissions from Batteries Meeting," February 8, 1990.

64. [p.3]: "In addition, there are many other activities in modern society that are giving rise to diffuse emissions of $\mathrm{Hg}$ [mercury], for example waste deposits [landfills], laboratories and dentists."

B. Hall, P. Schager and O. Lindqvist, "Chemical Reactions of Mercury in Combustion Flue Gases," Water, Air and Soil Pollution 56:3-14(1991).

65. Ip.452]: "Lodenius and Braunschweiler (1986) studied the possible emission lin some gaseous form] of toxic metals $(\mathrm{Hg}, \mathrm{Zn}, \mathrm{Cd}, \mathrm{Cu}$ ) from landfills, but the results were negative."

D.J. Lisk, "Environmental Effects of Landfills," The Science of the Total Environment, 100:415-468(1991).

M. Lodenius and H. Braunschweiler, "Volatilization of Heavy Metals from a Refuse Dump," The Science of the Total Environment. 57:253-255(1986). 
66. [p.253]: "A comparison with results from other moss-bag studies shows that the results from Iso-Huopalahti are, in general, a little higher than the background values from unpolluted areas, but at the same level as measured earlier in city areas. Consequently, the refuse dump does not seem to enhance the metal concentrations in air levels above normal values in urban areas."

M. Lodenius and H. Braunschweiler, "Volatilization of Heavy Metals from a Refuse Dump," The Science of the Total Environment. 57:253-255(1986).

67. [Telephone conversation]: F. Pohland reported observing reducing conditions in a landfill being studied by his research group, which presumably could have promoted reduction of mercury to the elemental form, but no mercury volatilization was reported observed.

F. Pohland, private communication to W.M. Shaub, June 22, 1992.

68. [p.5]: [As reported in Table 3] Mercury in a sanitary landfill in Finland during the period 7-8/1990 - reported average concentration in the working air of 0.030 micrograms per cubic meter (average value); 0.13 micrograms per cubic meter (maximum value).

"The mercury concentrations measured at the sanitary landfill fit with the values reported at four Swedish sites, 10-24 nanograms per cubic meter (Bergvall et al. 1988). This result could be expected because waste and landfill gas is known to contain mercury (Koch \& Vierle 1990), mercury has a low vapour pressure and there is passive gas flow to the atmosphere from the refuse bank. Although the mercury concentrations do not exceed the TLV, they may pose an environmental problem, because mercury emissions occur over a long period and a large area."

M. Ettala, "Gaseous Impurities of the Working Air in Waste Treatment," In Proceedings of the ISWA 6th International Solid Wastes Congress and Exhibition, Madrid, Spain, June 14-19, 1992.

G. Bergvall, R. Karlsson and S. Wallin, "Measurement of mercury vapor emissions from Swedish waste landfills," In Proceedings of the ISWA 5th International Solid Wastes Conference 2:55-60(1988), Copenhagen, Denmark, September 11-16, 1988.

K. Koch and 0 . Vierle, "Analytical investigations of heavy metals in gaseous effluents from a garbage dump," In Proceedings of the 3rd International KfK/TNO Conference on Contaminated Soil '90 1:827-828(1990), F. Arendt, M. Hinsenveld and W.J. van den Brink (Editors), Karlsruhe, Germany, December 10-14, 1990. 


\section{Atmospheric deposition}

69. [p.37]: "Atmospheric input [based on measurement of atmospheric mercury into a seepage lake (Wiener et al. 1990)] is typically about 15 micrograms per cubic meter per year; this number is a useful measure of northern hemisphere deposition."

N. Revis, "Mercury Speciation: Impacts on Aquatic Toxicity," In: "Florida State University, Proceedings of Workshop on Mercury Contamination in Florida: Imoacts and Solutions, Florida State Conference Center, Tallahassee, Florida, June 20-21, 1990.

J.G. Wiener, W.F. Fitzgerald, C.J. Watras and R.G. Rada, "Partitioning and bioavailability of mercury in an experimentally acidified Wisconsin Lake," Env. Toxicol. Chem, 9:909-918(1990).

70. [p.73]: "Therefore, it is believed that atmospheric mercury [deposition to lakes] can completely account for the mercury in northern Minnesota, and it is, therefore, unnecessary to search for geological sources."

E. Swain, "Mercury Sources and History: The Minnesota Experience," In: "Florida State University, Proceedings of Workshop on Mercury Contamination in Florida: Impacts and Solutions, Florida State Conference Center, Tallahassee, Florida, June 20-21, 1990.

71. [p.2]: "Many of the lakes with high mercury levels in the fish are remote and receive no direct industrial discharges of mercury or other pollutants, leading state officials to attribute a significant part of the problem to atmospheric deposition of mercury. Research by the Electric Power Research Institute [EPRI], a research organization funded by the utility industry, also suggests that atmospheric deposition can account for all of the mercury in some lakes.

C. Neme, Electric Utilities and Long-Range Transport of Mercury and Other Toxic Air Pollutants, Center for Clean Air Policy, Washington, DC, November 1991.

Wisconsin Department of Natural Resources, Mercury Emissions to the Atmosphere in Wisconsin, PUBL-AM-014, June 1986, p.2.

Minnesota Pollution Control Agency, Assessment of Mercury Contamination in Selected Minnesota Lakes and Streams, Report to the Legislative Commission on Minnesota Resources, December 1989, p.2.

Donald Porcella, "Mercury in the Environment," EPRI Journal, 15(3):46-49(April/May 1990).

72. [p.57]: "A wide range of concentrations of mercury in air has been reported during the last few years. These data indicate a background level of about 2 nanograms per cubic meter 
over Europe. Elemental mercury seems to be the dominant form in the atmosphere, however, there is also a water soluble fraction present. That fraction is found to constitute, on average, $5-10 \%$ of the total gaseous mercury during the winter and less during the summer. Mercury associated with particles in the atmosphere normally makes up only a small fraction of the total airborne mercury."

J.G.T. Bergstrom, "Mercury Behavior in Flue Gases," Waste Management and Research 4:57-64(1986).

0 . Lindqvist, "Fluxes of mercury in the Swedish environment: contributions from waste incineration," Waste Management and Research 4:35-44(1986).

\section{Batteries}

73. [p.1]: "Based on National Electrical Manufacturers Association (NEMA) estimates that each person uses about 1 pound of batteries per year, the estimated collection rate is about 10 percent."

U.S. EPA, "Precombustion Control of Mercury Emissions from Batteries - Meeting Summary," (February 8, 1990).

74. [p.6]: "Alkaline batteries accounted for an estimated 444 short tons, or 63 percent of discards of mercury in MSW in 1989.

"...The [battery] industry has announced its intention to reduce mercury in alkaline batteries to 0.025 percent by weight by 1992 , and to eventually eliminate all mercury from these batteries.

"...the amount of mercury discarded in mercury zinc batteries has declined over the years as other kinds of batteries (silver oxide, zinc air) have taken some of their market share.

"While mercury can be eliminated from alkaline batteries, it is an integral part of mercury zinc batteries. Therefore, the amount of mercury in this type of battery is not likely to be lowered.

"...It is projected that mercury zinc batteries will be the largest single source of mercury in MSW by 1995.

"FINAL DRAFT DELIVERABLE, "Characterization of Products Containing Mercury in MSW in the U.S. 1970 - 2000," A.T. Kearney and Franklin Assoc., Inc., [EPA Contract No. 68-W9-0040] January 1991.

75. [p.2]: "The NHNT program plans to continue to collect all types of household batteries in the near future, but Carl Hirth raised several questions about the long term future of the 
program and the advisability of requiring household battery removal in the NSPS and guidelines. His questions included, (1) is it necessary to collect all types of batteries to reduce emissions or should specific types be targeted? (2) what types of storage, handling, and transport systems should be used to ensure safety? (3) are there any alternatives for disposal of collected batteries other than a hazardous waste landfill? (They have found that sanitary landfills will not accept drums of batteries and hazardous waste landfilling is expensive.) (4) Will there be recovery processes for any types of batteries other than mercury or silver oxide button cell batteries?

"...In response to Fred Porter's question on why only 10 percent removal has been achieved, Mr. Hirth said the battery collection program is only a small part of the NHNT solid waste program, it has a low priority in terms of funding, and there has been limited publicity. Furthermore, retailers that are part of national chains have refused to participate in battery collection, and in rural areas collection locations are not nearby many residences. David Hurd, with Bronx 2000, commented that 10 percent is good for a voluntary program. He and Carl Hirth thought that with aggressive publicity, a level of 20 or 25 percent might be achieved. They also commented that the public would likely resist mandatory collection programs, and that mandatory programs would entail high enforcement costs."

U.S. EPA, "Precombustion Control of Mercury Emissions from Batteries - Meeting Summary," (February 8, 1990).

76. [p.3]: "Mr. Johnson [Hennepin County, MN] said the county has not found a way to dispose of the collected batteries. One company wanted $\$ 500 /$ ton to put them in a sanitary landfill in another state. There are no battery recovery processes in the U.S. for household batteries other than button cells; and on a trip to Europe, Mr. Johnson observed that most countries were storing collected alkaline batteries because there was a lack of recovery or disposal options. Therefore, Hennepin County is storing the collected batteries. Elevated ambient mercury levels were detected with a vapor sniffer in the store-room when the containers holding the batteries were opened."

\section{U.S. EPA, "Precombustion Control of Mercury Emissions from Batteries - Meeting Summary," (February 8, 1990).}

77. [p.6]: "Ms. Schlierer [Mercury Refining Company] presented a brief overview of the availability of recovery processes for various types of household batteries. She commented that no economically feasible technology to recover carbon-zinc and alkaline batteries had been demonstrated. A facility in France recovers both nickel and cadmium from nickelcadmium batteries. However, in the U.S. only one company in Pennsylvania, Inmetco, accepts nickel-cadmium batteries.

"...Mercury Refining Company recycles mercury oxide and silver oxide button cell batteries. The mercury oxide batteries contain about $\mathbf{3 5}$ percent mercury. The batteries are put in a 'retort' oven along with other mercury-containing items and heated to 1000-1200 degrees Fahrenheit. Mercury vapors generated in the oven are collected in a condenser operated at 
80-100 degrees Fahrenheit. The collected mercury goes through two more purification steps, and is then sold for use in dental work, fluorescent lights, thermometers, and batteries. Other liquids are sent to wastewater treatment processes or hazardous waste incinerators. Solids including battery casings are sent to a hazardous waste landfill, although they usually pass the EP toxicity test. When a shipment contains mainly silver oxide batteries, the solids are further processed to concentrate the silver, which is sold to another refiner for purification.

"In 1989, Mercury Refining Company recycled over 28,000 pounds of button cell batteries. They currently receive button cell batteries from seven communities."

U.S. EPA, "Precombustion Control of Mercury Emissions from Batteries - Meeting Summary," (February 8, 1990).

78. [p.4]:"...(batteries have been the principal source of mercury in municipal solid waste going to incinerators)."

C. Neme, Electric Utilities and Long-Range Transport of Mercurv and Other Toxic Air Pollutants, Center for Clean Air Policy, Washington, DC, November 1991.

79. [p.136]: "Batteries were a very small component of the MSW, making up $0.03 \%$ of the MSW sorted. Most of these were ' $D$ ' and 'AA' size carbon and alkaline cells. No button (mercury) batteries were found even though the fines were inspected to see if any of these batteries were present."

D. Hilton, H.G. Rigo and A.J. Chandler, "Composition and Size Distribution of a BlueBox Separated Waste Stream," In: Proceedings, SWANA 6th Annual Waste-to-Energy Symposium, Minneapolis, MN, January 28-30, 1992.

80. [p.55]: [Germany] "Examples of applications containing mercury are fungicides in paints, thermometers, electronic components and fluorescent tubes (Lorber, 1985). More than $50 \%$ of the total mercury content in garbage is attributable to used batteries. This high degree of pollution is not attributable primarily to mercury oxide batteries but rather to alkaline manganese batteries, which are only separated today in the rarest cases (Genest \& Reimann, 1985). The most effective method to reduce the quantity of mercury in untreated garbage would be to focus on collecting used batteries separately."

D.O. Reimann, "Mercury Output from Garbage Incinerators," Waste Management \& Research 4:45-56(1986).

K. Lorber, "The Composition of Garbage and the Harmful Substances Emitted by Garbage Incineration Facilities," in Garbage Incineration and Flue Gas Purification, J. Thome-Kosmiensky, Ed., 7:559-594(1983).

W. Genest and D. Reimann, "Garbage Problems from Used Batteries," Mull und Abfall Z:217-224(1985). 
81. [p.464]: "For the past three years, efforts have been made to reduce mercury-bearing components in the MSW stream. These programs center primarily around household battery collection programs which generally have had a very limited success in terms of citizen participation."

R.M. Hartman and M.L. Smith, "The Beneficial Co-existence of RDF Technology with Recycling and Environmental Protection Goals," in Proceedings of 2nd U.S. Conference on MSW Management: Moving Ahead, U.S. EPA, Arlington, VA, June 2-5, 1992.

82. [p.1]: [re European battery management practices] "Batteries sold in Europe contain about 180 metric tons [tonnes] of $\mathrm{Hg}$ per year. Nearly $85 \%$ of the $\mathrm{Hg}$ is used in Alkaline Batteries. (In Japan $60 \%$ of the $\mathrm{Hg}$ is consumed in the manufacture of Alkaline batteries.)

"There are no $\mathrm{Hg}$ recycling plants in Europe, and it is not likely that any will be built soon.

"...Most batteries that are separated from the waste stream wind up in long term storage in deep underground salt domes in West Germany. Because of the cost of this option most countries only send $\mathrm{Hg}$ or $\mathrm{Cd}$ batteries to these sites. Thus they only control button cells and/or rechargeables or they manually separate them from the mixed battery collections.

"There is a growing awareness and concern over the release of mercury gas vapors into the ambient air as a result of the storage, collection, separation, and processing of spent batteries. In Denmark, $\mathrm{Hg}$ has been measured at levels from .015 to 2.5 micrograms per cubic meter in various battery storage areas, and from .75 to .92 micrograms [per cubic meter] above manual sorting tables. In a closed container of mixed batteries, stored for 4 months, a level of 74.5 micrograms per cubic meter was measured. There have also been concerns raised about the reaction of zinc carbon batteries with alkaline batteries during mixed storage, and the emission of $\mathrm{Hg}$ gas from landfills (Sweden)."

S.J. Levy, "European Battery Management Practices," Presented to OAQPS "Precombustion Control of Mercury Emissions from Batteries Meeting," February 8, 1990.

83. [p.117]: [As reported in Table 7] "Incinerator $\mathrm{M}, \mathrm{Hg}=0.83(+/-) 0.81$ milligrams/kilogram; Incinerator $\mathrm{B}, \mathrm{Hg}=2$ milligrams per kilogram " [Authors also state: "...the values of mercury for incinerator $M$ may be influenced by a well functioning battery collection system.": authors also cite an earlier study in which $\mathrm{Hg}$ in MSW is reported as 5 milligrams per kilogram (EWAG, 1982)]

P.H. Brunner and H. Monch, "The flux of metals through MSW incinerators," Waste Management 4:105-119(1986).

Swiss Federal Institute for Water Resources and Water Pollution Control (EWAG), Unpublishèd results, Dubendorf, Switzerland (1982). 


\section{N. Paints/pigments}

84. [p.8]: "Mercury has a long history of use in pigments, but it is difficult to quantify the uses for pigments containing mercury. It appears that most of the mercury in pigments is used in plastics, often in combination with cadmium, but uses also include paints, printing inks, rubber, textiles, and others. Based on the data available, it was estimated that 10 tons of mercury in pigments were discarded in 1989. This was 1.4 percent of total discards.

"Uses of mercury in pigments has been declining steadily. Cadmium-mercury pigments are no longer manufactured in the U.S., but some imports were identified. Since there is continuing pressure on pigment makers to eliminate heavy metals...it was projected that use of mercury in pigments will continue to decline rapidly."

"FINAL DRAFT DELIVERABLE, "Characterization of Products Containing Mercury in MSW in the U.S. 1970 - 2000," A.T. Kearney and Franklin Assoc., Inc., [EPA Contract No. 68-W9-0040] January 1991.

85. [p.3]: "Although recent EPA and industry decisions will reduce mercury emissions by halting the use of mercury as a biocide in [latex] paints and reducing the use of mercury in batteries, these actions may not be sufficient to adequately address environmental threats posed by mercury emissions."

C. Neme, Electric Utilities and Long-Range Transport of Mercury and Other Toxic Air Pollutants, Center for Clean Air Policy, Washington, DC, November 1991.

U.S. EPA, "Use of Mercury Compounds in Indoor Latex Paint to be Eliminated," Press Release, June 29, 1990.

86. [p.4]: "... (evaporation from paints may have been the largest source of mercury emissions in the U.S.)."

C. Neme, Electric Utilities and Long-Range Transoort of Mercury and Other Toxic Air Pollutants, Center for Clean Air Policy, Washington, DC, November 1991.

87. .[p.27]: "Perhaps most importantly, as Table 2-3 indicates, the use of mercury in paints declined by $35 \%$ between 1980 and 1989 , the last year for which information is available."

C. Neme, Electric Utilities and Long-Range Transport of Mercury and Other Toxic Air Pollutants, Center for Clean Air Policy, Washington, DC, November 1991.

88. [p.28]: "The magnitude of mercury emissions from paints can be expected to fall even more precipitously in the near future. Indeed, as a result of two recent regulatory 
developments, paints will cease to be a major source of mercury in the very near future. EPA's July 1990 decision to ban the use of mercury in indoor latex paints was the first of these developments. The second was a decision by the manufacturers of mercury biocides in mid-1991 to take their mercury products off the market rather than go through the process of re-registering mercury as a biocide with EPA. These two decisions eliminate what might have been the largest source of U.S. mercury emissions."

C. Neme, Electric Utilities and Leng-Range Transport of Mercury and Other Toxic Air Pollutants, Center for Clean Air Policy, Washington, DC, November 1991.

55(126) Federal Register June 29, 1990, pp.26754-26756.

56(105) Federal Register May 31, 1991, pp.24807-24809.

O. Fossil fuel combustion

89. [p.7]: "Uncontrolled emissions [of mercury] from a typical $500 \mathrm{MW}$ plant would be about 500 pounds per year."

W. Chow et al., "Managing Air Toxics," Paper No. 90.108.1, Presented at the 83rd Annual Air and Waste Management Association Meeting, Pittsburgh, PA, June 25-29, 1990.

90. [p.9]: "Mercury levels in U.S. coals vary from about 0.01 to $8 \mathrm{ppm}$. Typical values, however, are about $0.24 \mathrm{ppm}$ for Appalachian coals, 0.14 for Interior Eastern coals, and 0.21 ppm for Illinois Basin coals. Mercury is probably emitted primarily in its elemental form, but it could also be in one of its many combined forms in much lower concentrations."

W. Chow et al., "Managing Air Toxics," Paper No. 90.108.1, Presented at the 83rd Annual Air and Waste Management Association Meeting, Pittsburgh, PA, June 25-29, 1990.

Coal Conversions Systems Technical Data Book, March 1982.

Estimating Toxic Air Emissions From Coal and Oil Combustion Sources, Draft Final Report, DCN No. 88-203-080-19-04, Radian Corp., June 1988.

I. Smith. "Trace Elements from Coal Combustion: Emissions," IEA Coal Research, IEACR/011, June 1987.

91. [p.9]: "Fossil fuel combustion [2260 tonnes of mercury emissions worldwide annually] also accounts for about 60 percent of anthropogenic emissions of mercury."

J.O. Nriagu, "Global Metal Pollution," Environment 32(7):7-33(1990). 
92. [p.4]: "fossil fuel combustion, principally coal combustion, is responsible for an estimated $50-60 \%$ of global man-made mercury emissions. Until recently, fossil fuel combustion, principally coal combustion, was responsible for $20-30 \%$ of man-made mercury emissions in the U.S. Electric utilities account for well over $80 \%$ of total U.S. coal consumption. Studies several years ago by the Wisconsin and Michigan Departments of Natural Resources suggest that $30-40 \%$ of their man-made mercury emissions were attributable to coal combustion, primarily by electric utility power plants."

C. Neme, Electric Utilities and Long-Range Transport of Mercury and Other Toxic Air Pollutants, Center for Clean Air Policy, Washington, DC, November 1991.

U.S. - Canada Memorandum of Intent on Transboundary Air Pollution, Emissions, Costs and Engineering Assessment, Work Group 3B, Final Report, June 1982, P.175.

U.S. EPA, An Exposure and Risk Assessment for Mercury, EPA \#68-01-3857 (1980).

Wisconsin Department of Natural Resources, Mercury Emissions to the Atmosphere in Wisconsin, p. 30; and Michigan Department of Natural Resources, Interoffice Memorandum from Robert Miller, Chief, Air Quality Division, to Delbert Rector, Deputy Director, January 12, 1989.

93. [p.21]: "the enormous volume of fuel burned by utilities can lead to significant emissions of trace metals. In 1987, utilities burned approximately 720 million tons of coal (about $80 \%$ of total U.S. consumption) and 180 million barrels of residual oil (about $40 \%$ of total U.S. consumption."

C. Neme, Electric Utilities and Long-Range Transport of Mercury and Other Toxic Air Pollutants, Center for Clean Air Policy, Washington, DC, November 1991.

U.S. Department of Energy, Energy Information Administration, Cost and Quality of Fuels for Electric tility Plants 1987, DOE/EIA-0191(87), p.3.

U.S. Department of Energy, Energy Information Administration, Annual Energy Review 1987, DOE/EIA-0384(87), Table 58.

94. [p.24]: "fossil fuel combustion, principally coal combustion, is one of the largest, if not the largest, man-made source of mercury air emissions. This appears to be true both globally and for the United States, and may be true for most states as well."

C. Neme, Electric Utilities and Long-Range Transport of Mercury and Other Toxic Air Pollutants, Center for Clean Air Policy, Washington, DC, November 1991. 
95. [p.27]: "the increase in mercury emissions from fossil fuel combustion over the last decade was probably not matched by an increase in emissions from non-fossil fuel sources."

C. Neme, Electric Utilities and Long-Range Transport of Mercurv and Other Texic Air Pollutants, Center for Clean Air Policy, Washington, DC, November 1991.

96. [p.30]: "The only definitive conclusions that can be drawn from the data presented in this section are that the relative importance of fossil fuel combustion, particularly by utilities, is increasing, and that the relative importance of paints and incinerators as sourc ss of mercury emissions is decreasing. Much more detailed analysis of these changes is needed."

C. Neme, Electric Utilities and Long-Range Transport of Mercury and Other Toxic Air Pollutants, Center for Clean Air Policy, Washington, DC, November 1991.

97. [p.30]: "The Wisconsin study, completed in 1986, suggested that coal combustion was the second largest source of man-miade mercury air emissions in the state, accounting for 1.98 tons $(32 \%)$ of the 6.18 tons of emissions in the state in 1983. Large electric utility power plants were responsible for about $85 \%$ of total emissions from coal combustion. Only application of latex paints was estimated to account for a greater proportion $(48 \%)$ of the state's total mercury air emissions. As suggested above, the relative proportion of coal combustion and latex paint application can be expected to increase and decrease, respectively, because of the recent decisions that will eliminate the use of mercury as a biocide for all paints.

"The Michigan Department of Natural Resources, using assumptions from the Wisconsin study, EPA emission factors, and their own emission inventory data, found coal combustion to be the largest source of man-made mercury air emissions in the state, accounting for 6.7 tons $(42 \%)$ of the estimated 15.9 tons emitted each year. Electric utility power plants were responsible for about $\mathbf{8 1 \%}$ of total emissions from coal combustion."

C. Neme, Electric Utilities and Long-Range Transport of Mercury and Other Texic Air Pollutants, Center for Clean Air Policy, Washington, DC, November 1991.

Wisconsin Department of Natural Resources, Mercury Emissions to the Atmesphere in Wisconsin, p.30.

Michigan Department of Natural Resources, Interoffice memorandum from Robert Miller, Chief, Air Quality Division, to Delbert Rector, Deputy Director, January 12, 1989.

98. [p.54]: "During combustion $\mathrm{Hg}$ [mercury] evaporates from coal and only a small part condenses onto fly ashes. It can be concluded that between 90 and $99 \%$ of $\mathrm{Hg}$ in coal is emitted to the atmosphere in a gas phase. An amount of $95 \%$ may be used as an average value to calculate the $\mathrm{Hg}$ emission factors from coal-fired power plants."

J.M. Pacyna and J. Munch, "Anthropogenic Mercury Emissions in Europe," Water, Air and Soil Pollution, 56:51-63(April 1991). 


\section{P. Natural Gas}

99. [p.22]: "Natural gas mercury concentrations apparently vary considerably, depending on the formation in which the gas is found. They may be high enough to account for modest, but not insignificant levels of mercury emissions nationwide. At worst, they may be comparable to the concentrations in low mercury couls; at best, they may be negligible. No data are available on mercury concentrations from various U.S. gas fields."

C. Neme, Electric Utilities and Long-Range Trarisport of Mercury and Other Toxic Air Pollutants, Center for Clean Air Policy, Washington, DC, November 1991.

M.D. Bingham, AMOCO Production Company, "Field Detection and Implications of Mercury in Natural Gas," in SPE Production Engineering, May 1990, pp.120-124.

100. [p.43]: "Natural gas contains trace amounts of mercury, with concentrations varying considerably. One report suggests mercury concentrations in natural gas typically range from one to 200 micrograms per cubic meter."

C. Neme, Electric Utilities and Long-Range Transoort of Mercury and Other Toxic Air Pollutants, Center for Clean Air Policy, Washington, DC, November 1991.

M.D. Bingham, AMOCO Production Company, "Field Detection and Implications of Mercury in Natural Gas," in SPE Production Engineering. May 1990, pp.120-124.

\section{Q. Speciation of mercury}

101. [p.3]: "Atmospheric $\mathrm{Hg}$ [mercury] is present in different physical and chemical forms, which determine its atmospheric transformation and transport capacities. The chemistry of $\mathrm{Hg}$ is thus of importance for the deposition pattern around point source emissions. In order to apply $\mathrm{Hg}$ cleaning methods in flue gases its speciation is also of importance. To investigate this under realistic conditions, a $17 \mathrm{~kW}$ propane fired gas generator was used, while the kinetics of specific $\mathrm{Hg}$ reactions were investigated in a continuous flow reactor. Elemental $\mathrm{Hg}$ is readily oxidized [time frame of seconds] by $\mathrm{Cl} 2$ and $\mathrm{HCl}$ both at room temperature and at elevated temperatures (up to 900 degrees Centigrade) but not by NH3, N2O, SO2 or H2S. It reacts with 02 if a catalyst, such as activated carbon, is present. A slow reaction between $\mathrm{Hg}$ and NO2 has also been noted."

B. Hall, P. Schager and O. Lindqvist, "Chemical Reactions of Mercury in Combustion Flue Gases," Water, Air and Soil Pollution 56:3-14(1991).

102. [p.59]: "Very small part of the emitted $\mathrm{Hg}$ Imercury] can be assumed to be in the particulate form due to the high volatility of $\mathrm{Hg}$ and the high effectivity of dust Iparticulate 
matter entrained in gas flows] control techniques. The assessment of the ratios of the two gaseous forms seems to be very difficult. The lack of more detailed data resulted in first assumption of the same lequal distribution between the two principal species: $\mathrm{HgCl} 2$ and elemental $\mathrm{Hg}$ ] partition for all fossil fuel combustion. Mercury from waste incineration is mainly [authors estimate $75-85 \%$ ] emitted as $\mathrm{Hg}(\mathrm{II})$ [the chloride], caused by the high $\mathrm{Cl} 2$ [chlorine] content of the waste. But the ongoing discussion showed some discrepancies in the $\mathrm{Hg}$ partitioning for nonl-]ferrous metal industry and $\mathrm{Cl} 2$ [chlorine] production. For transport modeling three separate preliminary emission data sets were prepared for the above mentioned $\mathrm{Hg}$ species."

J.M. Pacyna and J. Munch, "Anthropogenic Mercury Emissions in Europe," Water, Air and Soil Pollution, 56:51-63(April 1991).

\section{MERCURY FROM INCINERATORS}

\section{A. Amoints of waste incinerated}

103. [p.2]: [As reported in Table 1 - as percent of total waste generated; values in parentheses: first value is annual amount incinerated - millions of tons; second value is ratio of amount incinerated ic number of inhabitants of c( untry)] Sweden $=55 \%(1.8 / 0.21)$; Denmark $=65 \%$ (1.7/0.32); Germany $=30 \%(9.2 / 0.15)$;

The Netherlands $=40 \%(2.8 / 0.18) ;$ France $=42 \%(7.6 / 0.14)$; Spain $=6 \%(0.7 / 0.02)$; Italy $=18 \%(2.7 / 0.05)$; Great Britain $=8 \%(1.3 / 0.02)$; Hungary $=9 \%(0.3 / 0.03)$; USA $=16 \%$ (28.6/0.115); Japan $=72 \%(32 / 0.26)$.

K. Nilsson, "W'orldwide Trends in Solid Waste Incineration," In Proceedings of the ISWA 6th International Solid Wastes Congress and Exhibition, Madrid, Spain, June 14$19,1992$.

\section{B. Emission standards:}

104. [p.3]: [As reported in Table 2 (units of milligrams per cubic meter)] Germany (1989, based on $11 \%$ oxygen) $=0.1$ as a daily average; EEC $(1989$, based on oxygen $11 \%$ oxygen $/ 9 \%$ carbon dioxide) $=0.2$ [cadmium + mercury] as a monthly average; Netherlands (1989, based on $11 \%$ oxygen) $=0.05$ [cadmium + mercury] as an hourly average; France (1986, based on $7 \%$ oxygen) $=0.3$ [cadmium + mercury]; Sweden $(1986$, based on $10 \%$ carbon dioxide) $=0.08$ as a monthly average.

K. Nilsson, "Worldwide Trends in Solid Waste Incineration," in Proceedings of the ISWA 6tii !nternational Solid Wastes Congress and Exhibition, Madrid, Spain, June 1419, 1992. 
105. [p.2(8)]: [As reported in unlabeled table (units of milligrams per cubic meter); averaging, basis not stated] Germany $(1990)=0.05$ [cadmium + mercury + other Class I compounds]; Netherlands (1989) $=0.05$.

P. Lindgren, "Flexibility in wet flue gas cleaning systems with regard to e.g. adaption to future more stringent emission requirements," In Proceedings of the ISWA 6th International Solid Wastes Congress and Exhibition, Madrid, Spain, June 14-19, 1992.

106. [p.30]: "Measurements of mercury are recommended, preferably continuously, owing to its strong dependence on a variable input in the feed."

A. Sarofim and R. Seeker [Workgroup Rapporteurs], In: H. Yakowitz (OECD) [Symposium Rapporteur] Incineration of MSW - Scientific and Technical Evaluation of the State of the Art, Proceedings of an Experts' Symposium, U.S. Conference of Mayors, Washington, DC, September 1989 (Report date February 1990).

107. [p.33]: For mercury, a continuous monitor involving a resonant line absorption method is used on samples extracted from the stack (Kyoto Electronics). The limit on emission of mercury in Tokyo is 0.05 milligrams per normal cubic meter."

A. Sarofim and R. Seeker [Workgroup Rapporteurs], In: H. Yakowitz (OECD) [Symposium Rapporteur] Incineration of MSW - Scientific and Technical Evaluation of the State of the Art, Proceedings of an Experts' Symposium, U.S. Conference of Mayors, Washington, DC, September 1989 (Report date February 1990).

\section{Emission strengths:}

108. [p.163]: The continuous measurements of mercury in the flue gas from waste incineration plants [in Japan] showed that the mercury level normally ranges from 0.05 to U.15 milligrams/normal cubic meter with a peak of high concentration of 1-2 milligrams/normal cubic meter detected. This peak was experimentally confirmed to be attributed to mercury in waste mercury batteries and thermometers."

K. Nakazato, "Latest Technological Experiense of the Removal of Mercury in Flue Gas and the Management of Fly Ash from MSW Incinerator," Paper No. 100301 - 1990, National Waste Processing Conference - 14th. Biennial Conference (1990).

109. [p.16]: L.As reported in Table 1, mercury levels at various sites in units of milligrams/normal cubic meter dry gas 10\% CO2; as follows site listed first, then value in parentheses] "Linkoping (0.4); Uppsala(0.3); Avesta(0.4); nominal range of values (0.2 0.5)."

K. Carlsson, "Heavy metals from 'Energy from Waste' plants - comparison of gas cleaning systems," Waste Management \& Research 4:15-20(1986). 
110. [p.3]: [re mercury emission spikes] "...individual one or two hour test results of 6250 micrograms per dry standard cubic meter [at an incinerator facility cited] and 6763 and 7259 micrograms per dry standard cubic meter [at an incinerator facility cited] have been documented. No procedures are currently in place anywhere in this country to prevent the combustion of a large concentration of mercury bearing materials thoughtlessly thrown into the trash."

C.S. Volland, "Mercury Emissions from Municipal Solid Waste Combustion," Paper No. 91-35.1, Presented at the AWMA 84th Annual Meeting, Vancouver, BC, June 16-21, 1991.

J.E. Howes et al. (Battelle Columbus Laboratories) Characterization of Stack Emissions from Municipal Refuse to Energy Systems, EPA/500/S3-86/055, USEPA, Feb. 1987.

S.C. Ward et al. (Entropy Environmentalists, Inc.), "Measurement Methodology for Toxic Metals from Municipal Waste Combustors," In: Proceedings of Intn'l. Conf. on MWC 2:5C1-13(April 1989).

111. [p.1]: [Statement of typical range] Unabated emissions of mercury from municipal solid waste incinerators] $0.1-0.6$ milligrams per normal cubic meter.

K.B. Carlsson, "Dry Scrubbers for Energy from Waste Plants - Ten Years of Successful Development," In Proceedings of the ISWA 6th International Solid Wastes Congress and Exhibition, Madrid, Spain, June 14-19, 1992.

112. [p.4]: "It is estimated that approximately nine tons of mercury were emitted into the atmosphere by solid waste incinerators in Florida during 1989 (T. Rogers, Florida DER, pers. comm.)"

M.E. Roelke, D.P. Schultz, C.F. Facemire, S.F. Sundlof and H.E. Royals, Mercury Contamination in Florida Panthers. A report of the Florida Panther Technical Subcommittee to the Florida Panther Interagency Committee (December 1991).

113. [p.9]: [From Table 2] Worldwide atmospheric emissions of mercury from waste incineration is 1160 tonnes annually; energy production releases 2260 tonnes of mercury. (Compare with Table 1 ) in which it is shown that worldwide emissions of trace metals from natural sources to the atmosphere are 2500 tonnes.

J.O. Nriagu, "Global Metal Pollution," Environment 32(7):7-33(1990). 
114. [p.24]: "Emissions estimates by Nriagu (1989) suggest that coal combustion was by far the largest global source of mercury emissions to the atmosphere from human activities in 1983, with refuse incineration an important but distant second."

C. Neme, Electric Utilities and Long-Range Transport of Mercury and Other Toxic Air Pollutants, Center for Clean Air Policy, Washington, DC, November 1991.

J. Nriagu, "Natural Versus Anthropogenic Emissions of Trace Metals to the Atmosphere," in J.M. Pacyna and B. Ottar (Eds.) Control and Fate of Atmospheric Trace Metals, 1989, pp.3-13.

\section{Amounts of waste generated, combusted:}

115. [p.ES-9]: "Generation of municipal solid waste grew steadily between 1960 and 1988, from 88 million to nearly 180 million tons per year.

"...Between 1986 and 1988, generation increased from...167 million to 180 million tons per year. By [the year] 2000, projected...generation is...216 million tons. Projected MSW generation in the year 2010 is over 250 million tons.

"...combustion of MSW has been increasing again (to 25.5 million tons, or roughly 14 percent of generation, in 1988).

"...The report projects that more than 45 million tons of MSW will be combusted in 1995, and 55 rnillion tons will be combusted in 2000."

FINAL DRAFT DELIVERABLE, "Characterization of Products Containing Mercury in MSW in the U.S. 1970 - 2000," A.T. Kearney and Franklin Assoc., Inc., IEPA Contract No. 68-W9-0040] January 1991.

\section{E. Amounts of mercuny in the waste stream:}

116. [p.11]: "If the products cont-ining mercury in MSW are classified into combustible and noncombustible fractions, it is clear that most of the mercury is in the noncombustible fractions. This is because of the dominance of batteries as a source of mercury in MSW. Other noncombustible sources of mercury are lighting, thermometers, thermostats, and dental uses.

"Pigments comprise the largest share of the combustible fraction of products containing mercury, with paper coating the only other identified source. The pigments could be in plastics, inks, painted products, textiles, or similar combustible products.

"FINAL DRAFT DELIVERABLE, "Characterization of Products Containing Mercury in MSW in the U.S. 1970 - 2000," A.T. Kearney and Franklin Assoc., Inc., [EPA Contract No. 68-W9-0040] January 1991. 
117. [p.179]: "While efforts to keep mercury out of the garbage by directed recycling must be supported, they are too unreliable..."

H. Vogg, "Behavior of (heavy) metals in the incineration of municipal wastes," International Chemical Engineering 27(2):177-182(April 1987), and Chemie-IngenieurTechnik 56(10):740-744(1984)

118. [p.39]: "Solid fossil fuels, e.g., coals and peat, contain various mercury compounds, probably bound to sulphur in one way or another, usually amounting to $0.1-0.3$ milligrams of mercury per kilogram. The mercury content in municipal waste usually lies in the range 0.5 - 3.0 milligrams of mercury per kilogram and has a higher content of elemental or amalgamated mercury than fossil fuels."

O. Lindqvist, "Fluxes of Mercury in the Swedish Environment: Contributions from Waste Incineration," presented at the ISWA [Specialized Seminar] Incinerator Emissions of Heavy Metals and Particulates, Copenhagen, 18-19 September 1985.

119. [p.66]: [As reported in Table 1] "Hg = 5 grams/tonne of refuse"

H. Vogg, H. Braun, M. Metzger and J. Schneider, "The specific role of cadmium and mercury in MSW," Waste Management and Research 4:65-74(1986).

120. [p.117]: [Data for two different incinerator waste input streams in Germany as cited in Table 7] [first incinerator] $\mathrm{Hg}$ level is cited as "0.83 (plus/minus 0.81 ) ppm" [second incinerator] $\mathrm{Hg}$ level is cited as " $2 \mathrm{ppm}$." [NB authors suggest in regard to the first incinerator input waste stream that "...may be influenced by a well functioning battery waste collection system"]

P.H. Brunner and H. Monch, "The Flux of Metals Through Municipal Solid Waste Incinerators," Waste Management \& Research 4:105-119(1986).

121. [p.42]: "A recent study of the mercury distribution in the flue gas cleaning system at Malmo Abfalls varmeverk (Bergstrom and Lindqvist, 1985) has shown a mercury flow of 2 grams per ton [tonne] of waste."

O. Lindqvist, "Fluxes of Mercury in the Swedish Environment: Contributions from Waste Incineration," presented at the ISWA [Specialized Seminar] Incinerator Emissions of Heavy Metals and Particulates, Copenhagen, 18-19 September 1985.

J.G.T. Bergstrom and J. Lindqvist, "Mercury Removal from Flue Gases from SYSAV's Waste Heat Boiler Plant in Malmo, (with extended abstract in English) Report DRAV Nr 20, January 1985. 
122. [p.54]: "As a rough guess [re the amount of mercury in waste] a range of 0.5 to $9 \mathrm{~g}$ [grams]/t [tonne] of waste [as generated in Europe] can be concluded from the literature." [NB This corresponds to $0.5-9 \mathrm{ppm}$ of mercury in waste.]

J.M. Pacyna and J. Munch, "Anthropogenic Mercury Emissions in Europe," Water, Air and Soil Pollution, 56:51-63(April 1991).

O. Lindqvist, Waste Management and Research 4:35(1986).

S. Mitra, Mercury in the Ecosystem Trans Tech Publ. Ltd., Switzerland (1986).

123. [p.39]: [as reported in Table 1] "Mercury in untreated waste ranges from $0.3-14$ grams per tonne."

D.O. Reimann, Waste Management and Research 10:37-46(1992). INB the data presented is based on earlier references, but it is not clear from which reference the numbers derive.]

124. [p.7]: [As reported in Table 3] Range of mercury emissions in referenced incinerator studied is 1.4 - 2.6 ppmw; range reported for European urban wastes is $1: 7$ ppmw.

S. Cernuschi, M. Giugliano, I. de Paoli and U. Ghezzi, "The Flux of Residues and Heavy Metals Through a Municipal Solid Waste Incinerator," In Proceedings of the ISWA 6th International Solid Wastes Congress and Exhibition, Madrid, Spain, June 14-19, 1992.

125. [p.3]: "untreated waste in an industrialized area may contain 5 micrograms/gram [5 ppml, while if it is sorted and batteries are extracted, household waste may contain as little as 1 microgram/gram [1 ppm]."

B. Hall, P. Schager and O. Lindqvist, "Chemical Reactions of Mercury in Combustion Fiue Gases," Water, Air and Soil Pollution 56:3-14(1991).

O. Lindqvist, "Mercury Emissions from Swedish Waste Incineration Plants," Report OOK 88:09, ISSN 0283-8575 1-15 (In Swedish) (1986).

126. [p.2-13]: [Amounts of $\mathrm{Hg}$ in five samples of refuse as reported in unlabeled table] (ppmw units) $0.56,0.62,0.36,1.05$, and 0.95 .

NITEP, "The Combustion Characterization of Mass Burning Incinerator Technology Quebec sity," Book \#1, Volume IV, December 1987. 
127. [p.463]: [re preparation of RDF from MSW] "Finally, mercury was shown to be reduced on average by $36 \%$ to produce RDF in the range of 0.034 to 0.257 micrograms per gram."

R.M. Hartman and M.L. Smith, "The Beneficial Co-existence of RDF Technology with Recycling and Environmental Protection Goals," in Proceedings of 2nd U.S. Conference on MSW Management: Moving Ahead, U.S. EPA, Arlington, VA, June 2-5, 1992.

128. [p.45]: "Domestic garbage normally contains 3-4 grams of mercury per tonne."

D.O. Reimann, "Mercury Output from Garbage Incineration," Waste Management \& Research 4:45-56(1986).

129. [p.196]: "The overall estimated concentration of mercury in the trash characterized during the study was 3.9 ppm on an as-received (wet) basis and 5.8 ppm on a dry basis. The laboratory results are dominated by the one sample of alkaline and zinc carbon batteries, reported to have a mercury concentration of 0.29 percent $(2,900 \mathrm{ppm})$. This is estimated to account for $\mathbf{8 9}$ percent of the mercury represented by all of the laboratory samples.

"The waste category with the second highest average mercury concentration was 'other combustibles,' with a dry-basis average just under 8 ppm. This is almost entirely attributable to the winter sample, for which the SSM laboratory reported a concentration of $31.5 \mathrm{ppm}$. This sample was retested several times to verify the result."

M. Rugg and N.K. Hanna, "Mercury Concentrations in MSW Components in Cape May County, NJ," In: Proceedings, SWANA 6th Annual Waste-to-Energy Symposium, Minneapolis, MN, January 28-30, 1992.

130. [p.197]: In addition to the testing of wood from the sorted trash, four samples of lumber from loads of bulky waste were tested for mercury. Two of the four were samples of lumber that was either coated with a finish or chemically treated, while the other two were samples of unfinished and untreated lumber. Dry-basis mercury concentrations of $\mathbf{3 . 3}$ and $\mathbf{3 . 8}$ ppm were reported for the treated lumber, consistent with the use of mercury in biocides in paint. In the sample of untreated lumber tested by the SSM laboratory, no mercury was detected at a detection limit of $0.025 \mathrm{ppm}$, consistent with the absence of paint. However, SCS reported a concentration of $1.3 \mathrm{ppm}$ for the other sample of untreated lumber. It is possible that the reported mercury was contributed by a fungicide used to control the growth of brown mold on the lumber when it was first cut at the mill."

M. Rugg and N.K. Hanna, "Mercury Concentrations in MSW Components in Cape May County, NJ," In: Proceedings, SWANA 6th Annual Waste-to-Energy Symposium, Minneapolis, MN, January 28-30, 1992. 
131. [p.34]: "Although uses of mercury are diverse (e.g., in batteries, thermometers, switches, and fluorescent light bulbs), in Japan $80 \%$ of the $\mathrm{Hg}$ consumed is recycled.

"A. Sarofim and R. Seeker [Workgroup Rapporteurs], In: H. Yakowitz (OECD) ISymposium Rapporteurl Incineration of MSW - Scientific and Technical Evaluation of the State of the Art, Proceedings of an Experts' Symposium, U.S. Conference of Mayors, Washington, DC, September 1989 (Report date February 1990).

132. [p. 11]: [Percent distribution of $\mathrm{Hg}$ content in different household waste fractions as reported in unlabeled table] Plastics $(10 \%)$, paper $(13 \%)$, animal matter $(2 \%)$, vegetable matter $(6 \%)$, textiles $(4 \%)$, rubber and leather $(3 \%)$, metals $(60 \%)$, miscellaneous $(3 \%)$.

National Energy Administration and National Swedish Environment Protection Board, Energy From Waste, (1987).

\section{F. Speciation of mercury in incinerator flue gases:}

133. [p.40]: "It is reasonable to assume that all mercury compounds are transformed to elemental mercury during the combustion process since heating mercury compounds to temperatures above $\mathbf{7 0 0}$ degrees Centigrade leads to thermal decomposition giving elemental mercury.

"...[re post combustion zone] Evidently, time of flue gas residence, temperature and chemical composition in the flue gas are key factors for the formation of oxidized mercury compounds in a combustor."

O. Lindqvist, "Fluxes of Mercury in the Swedish Environment: Contributions from Waste Incineration," presented at the ISWA [Specialized Seminar] Incinerator Emissions of Heavy Metals and Particulates. Copenhagen, 18-19 September 1985.

134. [p.54]: "The $\mathrm{Hg}$ [mercuryl lin the waste that is fed to the incinerator] is usually $100 \%$ volatilized in any kind of chamber...

"Mass balances by Braun et al. (1986) showed that about $20 \%$ of $\mathrm{Hg}$ was bound in slag [ash] and $80 \%$ was emitted in a gaseous form."

J.M. Pacyna and J. Munch, "Anthropogenic Mercury Emissions in Europe," Water. Air and Soil Pollution, 56:51-63(April 1991).

H. Braun, M. Metzger and H. Vogg, Mull und Abfall 2/86:s.62-71(1986). 
135. [p.59]: Mercury from waste incineration is mainly [authors estimate $75-85 \%$ ] emitted as $\mathrm{Hg}$ (II) [the chloride], caused by the high $\mathrm{Cl} 2$ [chlorine] content of the waste. But the ongoing discussion showed some discrepancies in the $\mathrm{Hg}$ partitioning for non[-]ferrous metal industry and $\mathrm{Cl} 2$ [chlorine] production. For transport modeling three separate preliminary emission data sets were prepared for the above mentioned $\mathrm{Hg}$ species."

J.M. Pacyna and J. Munch, "Anthropogenic Mercury Emissions in Europe," Water, Air and Soil Pollution, 56:51-63(April 1991).

136. [p.57]: "Mercury in the flue gas from waste incineration is predominantly in the vapour phase at temperatures down to 140 degrees Centigrade. Only a small portion of mercury is metallic $\mathrm{Hg}$, most of it is oxidized [as $\mathrm{HgCl} 2$ ], which has a high vapour pressure at these gas temperatures."

J.G.T. Bergstrom, "Mercury Behavior in Flue Gases," Waste Management and Research 4:57-64(1986).

\section{G. Control technologies:}

137. [p.11]: "In general, the effectiveness of heavy metals emission control by diverse gas cleaning system designs appears to be inversely related to system outlet temperature. Testing in Sweden of a pilot wet scrubber downstream of an ESP indicated that, with subcooling of saturated flue gas to approximately 60 degrees Centigrade ( 140 degrees Fahrenheit), the total (particulates and gaseous) mercury emissions from a municipal waste incinerator were reduced to as low as 0.01 milligram per normal cubic meter (dry). Tests of a German municipal refuse incinerator equipped with a spray dryer followed by an ESP operating at 150 degrees Centigrade (302 degrees Fahrenheit) indicated that vapor-phase mercury emission alone was 0.05 milligram per cubic meter or greater, (11\% 02 basis). A dry injection facilit!" serving a municipal waste refuse incinerator in Sweden, with its downstream fabric filter operating at approximately 160 degrees Centigrade (320 degrees Fahrenheit), is reported to reduce particulate mercury to typically non-detectable concentration and gaseous mercury to the range of $0.012-0.065$ milligrams per normal cubic meter dry, (11\% 02 basis)."

T.C. Brna, W. Ellison and C. Jorgensen, "Cleaning of municipal waste incinerator flue gas in Europe." EPA Report No. EPA/600/D-88/015, January 1988.

138. [p.35]: "Spray drying and dry sorbent injection in combination with a fabric filter has shown $97 \%$ removal efficiency for most metals; for mercury the data shows a range of efficiencies from 10 to $90 \%$."

"A. Sarofim and R. Seeker [Workgroup Rapporteurs], In: H. Yakowitz (OECD) [Symposium Rapporteur] Incineration of MSW - Scientific and Technical Evaluation of the State of the Art, Proceedings of an Experts' Symposium, U.S. Conference of Mayors, Washington, DC, September 1989 (Report date February 1990). 
139. [p.36]: "Needs were noted for a better understanding of the conditions leading to mercury capture in a spray dryer/fabric filter and on how to apply some of the high efficiency collection devices as a retrofit to existing units."

"A. Sarofim and R. Seeker [Workgroup Rapporteurs], In: H. Yakowitz (OECD) [Symposium Rapporteur] Incineration of MSW - Scientific and Technical Evaluation of the State of the Art, Proceedings of an Experts' Symposium, U.S. Conference of Mayors, Washington, DC, September 1989 (Report date February 1990).

140. [p.123]: "Removal [of mercury] to levels below 15 micrograms per normal cubic meter were reported [specific technology not cited in this meeting summary paper]."

J.A. Hansen, "Seminar Summary - Incinerator Emissions of Heavy Metals and Particulates," Waste Management \& Research 4:121-125(1986).

141. [p.52233]: "A mercury emission guideline was also considered, but is not proposed today. As explained previously, available data indicate wide variation in mercury collection efficiency and emission rates, even for MWC's with GCP [good combustion practice] and SD/FF [spray dryer/fabric filter] controls. The reasons for this variability and the mechanisms affecting mercury emissions and collection are not understood. Therefore an emission level cannot be specified at this time. The EPA and industry are establishing a joint task force to investigate mercury emissions and control. The results of this investigation will be used to determine what action is appropriate with regard to mercury issues.

"Although today's proposal does not include a mercury emission guideline, it does include a prohibition on the combustion of household batteries as part of the materials separation provisions. As discussed in Section V, household batteries (including mercury oxide, alkaline manganese, silver oxide, and zinc carbon batteries) are thought to be a major source of mercury in MSW, and removal of these batteries would reduce mercury emissions.

"At promulgation, based on information that becomes available and the results of the task force investigation, it will be decided whether a mercury emission guideline is appropriate. It will also be decided whether it is appropriate to maintain the prohibition on combustion of household batteries (possibly in combination with a mercury emission level) or whether the prohibition should be removed."

U.S. EPA, "Emission Guidelines: Municipal Waste Combustors," [Proposed guidelines and notice of public hearing] 54 (243) Federal Register 52233, Wednesday, December $20,1989$.

INote: The prohibition on combustion of household batteries was never imposed by the Agency. As of early June 1992, according to an anonymous source, the Agency was considering an emission performance standard of ca 100 micrograms per cubic meter (or $80 \%$ mercury removal) if mercury emission controls are installed; if mercury emissions controls are 
not installed, then more proscriptive cadmium and lead emissions performance standards would be imposed than in the former case.]

142. [p.7]: "Controlling mercury emissions requires lowering the temperature of the gas to ca 300 degrees Fahrenheit [149 degrees Centigrade]. At this temperature acid gases begin condensing and acid gas control is required to prevent corrosion of equipment. Thus, mercury control effectively requires gas control. Mercury is adsorbed by carbon. Mass burn combustors achieve high carbon 'burn-out' and there is little carbon to adsorb mercury. RDF (refuse derived fuel) combustors do not achieve high carbon burn-out and there is carbon to adsorb mercury. Consequently, acid gas control alone achieves substantial mercury control on RDF combustors (ca $80 \%$ ), but achieves little control on Mass Burn combustors. Activated carbon injection controls mercury emissions by adsorbing mercury on carbon. Sodium sulfide injection controls mercury emissions by reacting with mercury to form mercuric sulfide. Activated carbon and sodium sulfide injection can reduce mercury emissions from Mass Burn combustors by $80 \%$. The cost of mercury control is in the range of $\$ 0.50$ to $\$ 1.00$ per ton of waste. As a point of reference, the cost of acid gas control is in the range of $\$ 10-\$ 40$ per ton of waste."

Office of Air Quality Planning and Standards, "Municipal Waste Combustors," U.S. EPA/OAQPS, Research Triangle Park, September 6, 1991.

143. [Private communication] Estimated costs of Hugo Petersen carbon based adsorbers ["moving" bed configuration] are ca $\$ 0.33$ per ton of waste processed based on application at a hypothetical 500 tpd plant [dual 250 tpd boilers], with 60,000 normal cubic meter per hour flue gas flow and one tpd of activated carbon. Capital costs of installation are ca $\$ 3$ to 4 million and coke costs are ca $\$ 50,000-\$ 100,000$.

W.K. Panknin, private communication to W.M. Shaub (1990).

144. [p.464]: "For the past three years, efforts have been made to reduce mercury-bearing components in the MSW stream. These programs center primarily around household battery collection programs which generally have had a very limited success in terms of citizen participation."

R.M. Hartman and M.L. Smith, "The Beneficial Co-existence of RDF Technology with Recycling and Environmental Protection Goals," in Proceedings of 2nd U.S. Conference on MSW Management: Moving Ahead, U.S. EPA, Arlington, VA, June 2-5, 1992. 
145. [p.35]: "A review of some recent studies of mercury distribution in the flue gases in waste heat boilers shows that a large part of the mercury can be retained on fly ash from electrostatic precipitators or fabric filters. About $20-80 \%$ [note the broad range] of the mercury is retained depending on the temperature over the filter, and the time of residence of the flue gases in the temperature range below $\mathbf{6 0 0}$ degrees Centigrade before the filter."

O. Lindqvist, "Fluxes of Mercury in the Swedish Environment: Contributions from Waste Incineration," presented at the ISWA [Specialized Seminar] Incinerator Emissions of Heavy Metals and Particulates, Copenhagen, 18-19 September 1985.

146. [p.57]: Oxidized mercury [predominantly as $\mathrm{HgCl} 2$ ] is absorbed by fly ash and will be captured on fabric filters. By injecting fly ash and lime before a fabric filter a high degree of collection can be achieved, both for hydrochloric acid and for mercury.

J.G.T. Bergstrom, "Mercury Behavior in Flue Gases," Waste Management and Research 4:57-64(1986).

147. "Up to $90 \%$ of the mercury can become attached to the dust [fly ash]. By optimizing the operation and with efficient dust [fly ash] removal it is therefore possible to limit mercury emissions to less than $0.3 \mathrm{~g}$ [grams]/ton [tonne] of incinerated wast 6 .

J.G.T. Bergstrom, "Mercury Behavior in Flue Gases," Waste Management and Research 4:57-64(1986).

148. [p.63]: "Since 1981 a dry flue gas cleaning system, designed and delivered by Flakt Industri $A B$ has been in operation at Malmo...

"...Separation efficiencies of mercury in the flue gas cleaning system of up to $89 \%$ have been measured."

J.G.T. Bergstrom, "Mercury Behavior in Flue Gases," Waste Management and Research 4:57-64(1986).

149. [p.49]: "The effectiveness of ESPs, baghouses and scrubbers in removing mercury from flue gas seems to be at least partially dependent on the temperature of the gas when it encounters the emissions control device. At lower temperatures, some mercury condenses on ash particles which are then removed by pollution controls; at higher temperatures, mercury remains a gas and escapes to the atmosphere. Cold-side ESPs and baghouses encounter the flue gas after it has had a chance to cool somewhat. Wet scrubbers cool the gas further, aiding in additional mercury removal. In contrast, hot-side ESPs, which are located much closer to the boiler to take advantage of the fact that higher flue gas 
temperatures lower ash resistivity, generally do not remove any of the mercury from the flue gas.

C. Neme, Electric Utilities and Long-Range Transport of Mercury and Other Toxic Air Pollutants, Center for Clean Air Policy, Washington, DC, November 1991.

W. Chow et al., "Managing Air Toxics," Paper presented at the AWMA meeting, Pittsburgh, PA, June 1990, p.9.

150. [p.50-51]: "activated carbon technologies was developed in Europe by Joy Technologies, Inc. Joy has conducted both pilot-scale and full-scale tests of the effect of injecting activated carbon into municipal solid waste flue gas. The activated carbon increased the mercury removal efficiency of a dry scrubber/ESP combination from $27 \%$ to $78 \%$ at an outlet temperature of 285 degrees Fahrenheit [F] and from $66 \%$ to $86 \%$ at outlet temperature of 230 degrees $F$. It also increased the mercury removal efficiency of a dry scrubber/baghouse combination from $69 \%$ (at 265 F) to between $91 \%$ (285 F) and $95 \%$ ( 230 F). This technology, for which both European and U.S. patent applications have been submitted, is currently being used at the Zurich Josefstrasse incinerator to meet stringent mercury emission standards. The cost of the technology has not been reported.

"The sodium hypochlorite technology was developed in Japan by NKK. The NKK mercury removal process involves adding the sodium hypochlorite to a wet scrubber to solubilize mercury in flue gas. The mercury is then removed from the scrubber waste water through reduction, volatilization, condensation and mercury separation processes. This technology is capable of mercury removal efficiencies of between $95 \%$ and $100 \%$. It has been tested on both a pilot plant and a full scale incinerator in Kyoto. The average mercury removal efficiency during one and a half years of operation at the Kyoto incinerator was $96.6 \%$. Again no cost estimates for this mercury removal process are available.

"The lignite coke technology was developed by Stadtwerke Dusseldorf AG in Germany. It was originally designed for NOx removal, but tests on a municipal solid waste incinerator showed that the lignite coke catalyst also adsorbed other pollutants, including mercury and other heavy metals, hydrochloric acid, SO2, ammonia and dioxins. Removal of all of these pollutants was nearly $100 \%$. The cost of this technology for installation on four 150 megawatt coal-fired power plant units was estimated to be about 0.9 Pfennings/kwh 10.5 cents/kwh), if approximately one-sixth of the 200 Deutschmark/KW capital costs are incurred each year (equivalent to annualizing costs over 30 years using a $17 \%$ real annual discount

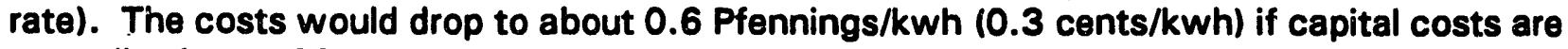
annualized over 30 years using a real annual discount rate.

"The last developing technology for mercury removal, alumina adsorption, is not yet being marketed. At least one version of the technology, however, has been patented in the United States. More recently, several Japanese scientists at Kanazawa University published the results of a study of the impacts of passing flue gas containing mercury through a sulfurimpregnated active alumina bed and then a sulfur-impregnated activated carbon bed. They concluded that this technology could accomplish 'complete removal of mercury vapor for a 
long period of time.' No cost estimates for the potential application of this technology to coal burning power plants are currently available." INB The referenced Japanese study is based on small-scale, in-laboratory studies. These studies do not prove commercial viability, nor do the Japanese researchers make such a suggestion.]

C. Neme, Electric Utilities and Long-Range Transport of Mercury and Other Toxic Air Pollutants, Center for Clean Air Policy, Washington, DC, November 1991.

J.R. Donnelly and K.S. Felsvang, "Joy/Niro SDA MSW Gas Cleaning Systems and New Developments," Paper presented at AWMA meeting, Anaheim, CA, June 1989. Ire activated carbon]

Y. Fujisawa et al., "Mercury Removal from flue Gas for Municipal Refuse Incineration Plants," NKK Technical Report, No. 123, September 1988. Ire sodium hypochlorite with scrubber]

C. Marnet et al., "Use of Lignite Coke for Reduction of NOx After Flue Gas Desulfurization," Paper prasented at the 14th Biennial Lignite Symposium on the Technology and Utilization of Low Rank Coal, Dallas, TX, May 1987 and at the 4th Symposium on Integrated Environmental Control, Washington, DC, March 1988. Ire lignite coke NOx technology]

Y. Otani et al., Kanazawa University, "Removal of Mercury Vapor from Air with SulfurImpregnated Adsorbents," Environmental Science \& Technology 22(6):711-717(1988). [re sulfur-impregnated alumina and carbon]

151. [p.709]: [NB Based on in-lab tests using a very clean gas system, not similar to actual flue gas conditions in this respect.l "In addition, activated carbon may also have a catalytic effect on the reaction between sulfur and mercury vapor

"...It is remarkable that the time it takes for the beds of sulfur-impregnated active alumina and zeolite to reach the adsorption equilibrium is several thousand times longer than for the sulfurfree adsorbents

"...Through the [in-lab] experiments on the adsorption of mercury vapor on sulfur-impregnated adsorbents, the following conclusions can be obtained. (1) Impregnation of sulfur increases the adsorption capacity of active alumina and zeolite by several orders of magnitude, and the equilibrium adsorbed mass is equal to the stoichiometrical value obtained from $\mathrm{Hg}+\mathbf{S} \rightarrow>$ HgS. (2) Sulfur-impregnated silica-based supporting materials have unusual concave breakthrough curves. (3) The deficiency of the sulfur-impregnated active alumina and zeolite beds (nonzero initial outlet concentration) can be covered by combining them with the sulfurimpregnated activated carbon-bed."

Y. Otani et al., Kanazawa University, "Removal of Mercury Vapor from Air with SulfurImpregnated Adsorbents," Environmental Science \& Technology 22(6):711-717(1988). [re sulfur-impregnated alumina and carbon] 
152. [p.56]: [Note: remarks made in context of applicability as control technology for abating coal fired utility power plant emissions] "Next to energy efficiency improvements, the most economically attractive option appears to be retrofitting one of the so-called 'developing technologies.' [these are identified in this report as being: activated carbon (with scrubber/ESP or scrubber/baghouse), sodium hypochlorite (with scrubber), lignite coke NOx technology, and sulfur-impregnated alumina and carbon] ......Unfortunately, however, it will require a number of years to demonstrate these technologies on a commercial scale."

C. Neme, Electric Utilities and Long-Range Transport of Mercury and Other Toxic Air Pollutants, Center for Clean Air Policy, Washington, DC, November 1991.

153. [p.3]: [NB Activated carbon technology, both in moving beds and as an injected material are already realizing commercial-scale use, both for coal-based and MSW-based applications; e.g., a recent technical report produced by Hugo Petersen Gesellschaft fur verfahrenstechnischen Anlagenbau mbH \& Co. KG identifies several applications of "moving" bed activated carbon technology. Power plants which utilize this technology are located at:] Mainz-Wiesbaden, Mannheim, Garath Dusseldorf Works, Oberhavel BEWAG A.G., HamburgStapelfeld (a waste incineration plant), Lausward Dusseldorf Works, Flingern Dusseldorf Works. Other plants that incorporate this technology have either come on line or are under construction since the time of the report. Results reported based on tests at the Stapelfeld [using an add-on pilot plant to test the technology] waste incineration plant, indicate mercury emission levels in the range non-detectable - less than 5 micrograms per cubic meter $111 \%$ oxygen/ wet).

U. Cleve, "Application of Carbon Based Adsorbers for Washing of Flue Gases," Presented at the 1989 Incineration Conference, Knoxville, TN (1989).

154. [p.8]: [Re injection of activated carbon] "Niro reports mercury captures of $90 \%$ or greater in most instances where the baghouse inlet temperature was below 248 degrees Fahrenheit [120 degrees Centigrade] and the carbon dosage was 15 milligrams per normal cubic meter or more, and at temperatures up to 284 degrees Fahrenheit [140 degrees Centigrade] where the dosage was about 50 milligrams per normal cubic meter or more.

"Ire injection of sodium sulfide] At the Hogdalen, Sweden facility which is equipped with a DSI/FF [dry sorbent injection/fabric filter], Flakt ran some 24 tests over four years and generally achieved mercury captures of 80 to $90 \%$. Higher removals were achieved when the baghouse was operated below 280 degrees Fahrenheit. Tests have also been performed at the Burnaby, British Columbia incinerator also equipped with a DSI/FF. The original compliance test had shown relatively high, 346 micrograms per dry standard cubic meter (11\% 02), mercury emissions and less than 10\% removal. Initial tests with Na2S yielded only 55-60\% removal. However a third test, at higher dosages, improved capture to about $85 \%$. The use of Na2S prompts certain safety concerns with handling as well as concern for corrosion problems." 
C.S. Volund, "Mercury Emissions from Municipal Solid Waste Combustion," Presented at the 84th Annual AWMA Meeting, Vancouver, BC, 16-21, 1991.

K.S. Felsvang, T.S. Holm and B. Brown, "Control of Mercury and Dioxin Emissions from European MSW Incinerators by Spray Dryer Absorption Systems Using Rotary Atomizers," Presented at the AlChE 1990 Summer National Meeting, San Diego, CA, 19-22 August 1990.

M. Hereth, Radian Corp., Trip report [EPA Air Docket No. A-89-08] submitted to U.S. EPA, 7 May 1990.

155. [p.172]: "Relcent technology developed by the NKK Corporation removes up to $87 \%$ of the mercury contained in flue gases emitted by incinerators.

"Outstanding featuriss of the process include the advantages that large equipment investments are not required, unlike conventional wet-type technology, and that it can be installed at an incinerator operating with a dry-type desulphurisation unit.

"The process involves a special macromolecular solution which is atomized then injected into flue gases, being forced to react with gaseous mercury. This forms mercury particles that are easily collected with a filter.

"NKK of London has conducted two types of demonstration tests on the process at a waste incinerator. A macromolecular solution (chelate solution) that inherently catches metals was first injected together with hydrated lime to rernove such harmful substances as sulphur oxides from flue gases, and then injected alone.

"The flue gas temperature was wet at 200 degrees Centigrade, and its air flow was set at $37,000-48,500$ cubic metres/hour in one test and 4,400-4,900 cubic metres/hour in the other. Two filter types, one using electrostatic precipitators and the other made of fibres were compared.

"The test results were very satisfying, with low mercury concentrations of $0.01-0.09$ milligrams/cubic metre/hour being recorded. These results show that between $50-87 \%$ of the mercury had been removed, and the removal rate varied little even when filters were changed.

"Due to dry battery cells, fluorescent lamps and other products containing mercury getting mixed with household and commercial waste, flue gases from waste incinerators reportedly contain mercury of around 0.1-0.5 milligrams/cubic metre.

"To remove mercury from flue gases, wet-type processes have been commercialized, whereby mercury and acidic air pollutants are forced to react in a special solution. However, wet-type processes are disadvantageous in that they use large amounts of water and consequently require a large-capacity waste water treatment facility. 
"This NKK-developed process is available as a unit that can easily be assembled with a tank, a pump and pipes. Therefore, it can be used with existing incinerators without a major refit. The company plans to continue its comparative tests by varying solution amounts, particle sizes and other specifications to further improve the process."

(staff article), "Mercury removal process developed," Waste Management (April 1992).

156. [p.1]: [Abstract] "The Clean Air Act Amendments of 1990 require the U.S. Environmental Protection Agency (EPA) to set emission limits for cadmium (Cd), Lead (Pb), and mercury $(\mathrm{Hg})$ for municipal waste combustors (MWCs). To aid developing $\mathrm{Hg}$ emission rules, tests were conducted in July and August 1991 on a 360-tonne(400 ton)/day mass burn MWC at the Ogden Martin Systems of Stanislaus, Inc. (OMSS) facility near Crows Landing, CA. The primary objective was to evaluate the effectiveness of powdered activated carbon (C) in controlling $\mathrm{Hg}$ emission. The $\mathrm{C}$ was injected into flue gas at both the economizer outlet and spray dryer absorber (SDA) inlet, as well as into the lime slurry fed to the SDA, during separate test conditions.

"Secondary test objectives were to [the] evaluate (1) the impact of ammonia (NH3) slip from the selective noncatalytic reduction (SNCR) system on $\mathrm{Hg}$ control, (2) the effect of lime stoichiometry in the SDA/fabric filter (FF) system on $\mathrm{Hg}$ emission, (3) the effect of FF gas temperature on $\mathrm{Hg}$ emission, and (4) at several locations from the unit tested (Unit 2).

"Results of the tests indicated that $\mathrm{C}$ addition was effective in improving $\mathrm{Hg}$ removal, the removal increasing with increasing $\mathrm{C}$ feed rate. $\mathrm{Hg}$ removal improved from about $30 \%$ without $C$ addition to over $90 \%$ at the highest feed rate tested. The test data obtained for evaluation of the secondary test objectives suggested that (1) NH3 addition (which occurred with low slip) had no apparent adverse effect on $\mathrm{Hg}$ control, (2) lime stoichiometry had no effect on $\mathrm{Hg}$ emissions over the narrow range studied, (3) the FF gas temperature over the range tested did not affect $\mathrm{Hg}$ control, and (4) the $\mathrm{Hg}$ content of ash/residue stream samples remained relatively constant over a period of 28 days in samples held at 54 degrees Centigrade (130 degrees Fahrenheit)."

T.G. Brna, J.D. Kilgroe and C.A. Miller, ,U.S. EPA, "Reducing Mercury Emission from Municipal Waste Combustion with Carbon Injection into Flue Gas," Presented at ECO WORLD'92, June 1992.

152. [p.2]: "For the past 6 months we have noticed a strong growing interest in the United States in our Activated Carbon Technology. This is not surprising, because this technology is increasingly used in Germany and other European countries.

"Hugo Petersen, a sister company of Steinmuller, is one of the major suppliers of this technology and was deeply involved in its development to the present level of reliability and effectiveness. 
"The Activated Carbon Technology allows us to guarantee values which are, in most cases, one order of magnitude lower than the already stringent [German] standards [i.e.., 100 micrograms per normal cubic meter]."

W. Panknin, private communication to W.M. Shaub, February 20, 1990.

158. [p.8]: "Lee County, FL (Ft. Myers area) ofíicials told a Florida DER Hearing officer that it would use an activated carbon injection system to absorb mercury emissions. Citing Ogden Martin experience at its Stanislaus County, CA plant, they estimate that $70-80 \%$ of the mercury would be removed."

F. McManus (Editor), Resource Recovery Report 16(8) June 1992.

159. [p.9]: [Synthesis of information from Figure 6; table 4 and accompanying discussion] At the Umea district heating plant with Na2S injection in the temperature range 150 to 170 degrees Centigrade, $97 \% \mathrm{Hg}$ removal achieved with 0.2-0.3 kilograms $\mathrm{Na25}$ added per ton of waste - outlet emission corresponds to 0.001 milligrams per normal cubic meter based on $10 \%$ carbon dioxide, dry gas. At the Bollmora district heating plant with coke powder additives in the temperature range 150 to 170 degrees Centigrade, $97 \% \mathrm{Hg}$ removal achieved with $1-2$ kilograms coke added per ton of waste - outlet emission corresponds to 0.005 milligrams per normal cubic meter based on $10 \%$ carbon dioxide, dry gas.

"Both methods [sodium sulfide or carbon addition] were reviewed in the spring of 1986 when it was discovered that the normal concentration of unburned carbon in the flue gas from Unit 3 at Stockholm/Hogdalen was too low for efficient removal [of mercury]."

K.B. Carlsson, "Dry Scrubbers for Energy from Waste Plants - Ten Years of Successful Development," In Proceedings of the ISWA 6th International Solid Wastes Congress and Exhibition, Madrid, Spain, June 14-19, 1992.

T. Viberg, Miljokonsulterna, report No. MKS-91/132 (1991).

B.A. Johansson, AF-Energikonsult, report No. 400399-02 (1991).

160. [p.163]: "Several mercury removal systems have been developed and installed in the flue gas stream of incineration plants in Japan. Both a liquid chelating agent injection system and a sodium hypochlorite injection system at the wet scrubber have achieved more than $90 \%$ removal of mercury."

K. Nakazato, "Latest Technological Experience of the Removal of Mercury in Flue Gas and the Management of Fly Ash from MSW Incinerator," Paper No. 100301 - 1990, National Waste Processing Conference - 14th Biennial Conference (1990). 
161. [p.164]: "Most of the waste incineration plants built in major [Japanese] cities and their surrounding cities, where $\mathrm{HCl}$ and SOx emissions have been significantly controlled, have been conventionally equipped with a wet scrubber. Investigation of the wet scrubber for its mercury removal efficiency level is only in the range $30-70 \% . "$

K. Nakazato, "Latest Technological Experience of the Removal of Mercury in Flue Gas and the Management of Fly Ash from MSW Incinerator," Paper No. 100301 - 1990, National Waste Processing Conference - 14th Biennial Conference (1990).

162. [p.164]: "This [liquid chelatingl system is designed with a caustic soda-based gas scrubbing line, into which a liquid chelating agent and cupric chloride are injected for absorption of atomic mercury contained in the flue gas.

"In general, mercury in the flue gas at the wet scrubber entrance occurs in three forms: water soluble mercury, slightly water soluble mercury and atomic mercury in the approximate ratio of $8: 1: 1$. Water soluble mercury is assumed to be identified as $\mathrm{HgCl} 2$ formed by reaction of mercury and $\mathrm{HCl}$ in the flue and the electrostatic precipitator. Therefore, this form of mercury can be absorbed even in a conventionally-used wet scrubber, which, however, is not capable of absorbing the other two forms of mercury: atomic and slightly water soluble mercury.

"[There is a] relationship between the $\mathrm{pH}$ of various absorbing solutions and the percent absorption of atomic mercury in the solutions [figures that show the percent absorption of atomic mercury as a function of $\mathrm{pH}$ of the absorbing solution are presented in the report].

"The scrubbing waste water containing mercury is subjected to coagulating sedimentation with the addition of liquid chelating agent at a concentration several times the amount of copper, followed by fixation of the sludge."

K. Nakazato, "Latest Technological Experience of the Removal of Mercury in Flue Gas and the Management of Fly Ash from MSW Incinerator," Paper No. 100301 - 1990, National Waste Processing Conference - 14th Biennial Conference (1990).

163. [p.165]: This [sodium hypochlorite injection] system is designed with a wet scrubber, to which sodium hypochlorite is injected at a concentration of several tens of ppm for reaction with mercury to form mercuric chloride for absorption. The system provides for a mercury removal efficiency of $90-95 \%$."

K. Nakazato, "Latest Technological Experience of the Removal of Mercury in Flue Gas and the Management of Fly Ash from MSW Incinerator," Paper No. 100301 - 1990. National Waste Processing Conference - 14th Biennial Conference (1990). 
164. [p.1]: [re use of chelating compounds for removal of mercury from flue gas flows in incinerators] "Since this process is not yet commercialized, the costs are not available."

Y. Makishima, NKK America, Private letter communication to W. Shaub, June 18, 1992.

165. [p. 1-4]: [(Japanese researchers) re: control of incinerator emissions] "Mercury, which stands for heavy metals is also generated by spent dry cells, clinical thermometers, and fluorescent lamps. The substance evaporates in the combustion process and the exhaust gas would normally contain 0.1 to 0.5 milligrams per dry normal cubic meter of volatile matter. The dry cell manufacturers took steps to eliminate the use of mercury in manganese dry cells followed by further steps to completely suspend the use of mercury in alkali dry cells, starting January, 1992.

"In addition to the steps just mentioned, some of the local governments have launched programs to make a separate collection of spent dry cells from the municipal refuse. However, the separate collection system is not sufficient for constraining mercury emission. So, $\mathrm{Hg}$ removal by exhaust gas treatment is considered indispensable. So far, the wet process was effective in removing mercury, but from a standpoint of required corrosion protection of equipment and complexity of operation, there is a strong demand for the development of a complete dry mercury removal process with efficiency equivalent to that of the wet process. In responding to such a need, NKK has performed tests of atomizing liquid chelate on the dry type exhaust gas treatment process. The test was performed based on the perspective that most of the mercury content in exhaust gas is in a gaseous state, so mercury in exhaust gas would be reacted with liquid chelate and [caught] by the downstream dust collector. This paper gives the general outline of the process and describes the test results.

"...[re: effects of addition of heat resistant liquid chelate] When the heat resistant chelate solution is not atomized in the exhaust gas, the $\mathrm{Hg}$ removal rate at the dust collector ranges between 20 to 50 percent, while when the heat resistant chelate solution is atomized in the exhaust gas, the $\mathrm{Hg}$ concentration is removed to a level of 0.01 to 0.093 milligrams per normal cubic meter at the outlet of dust collector. The removal rate was raised to a level of 50 to 87 percent. Accordingly, it was verified that atomizing the heat resistant chelate solution in the exhaust gas is effective in removing the mercury.

"...[Conclusions of investigators] By atomizing heat resistant chelate solution in exhaust gas, the results obtained from the mercury removal tests are...(1) atomizing heat resistant che te solution in exhaust gas lowers $\mathrm{Hg}$ concentration at the outlet of dust collector; (2) the $\mathrm{Hg}$ removal by atomizing heat resistant chelate solution is primarily due to reaction with mercuric chloride contained in exhaust gas. Since the test results show the effects of $\mathrm{Hg}$ removal by heat resistant chelate solution, further tests and development work will be carried out by the changing atomizing conditions of solution."

E. Shibuya and K. Yoshikubo, "Removal of $\mathrm{Hg}$ Content from Flue Gas by Liquid Chelate," Provided to W.M. Shaub June 18, 1992 by Y. Makashima, NKK America. 


\section{H. Mercury in ash from incinerators:}

166. [p.6]: "The concentration of heavy metals and other compounds in a small quantity of flyash makes future emissions from leachate much easier to control."

K. Nilsson, "Worldwide Trends in Solid Waste Incineration," In Proceedings of the ISWA 6th International Solid Wastes Congress and Exhibition, Madrid, Spain, June 1419, 1992.

167. [p.35]: "Preliminary tempering and leaching tests indicate that most of the filterremoved mercury is suitable for deposition."

0 . Lindqvist, "Fluxes of Mercury in the Swedish Environment: Contributions from Waste Incineration," presented at the ISWA [Specialized Seminar] Incinerator Emissions of Heavy Metals and Particulates, Copenhagen, 18-19 September 1985.

168. [p.42]: "Mercury removed with the fly ash and lime is strongly bound and does not evaporate to any appreciable amount during handling and transport."

O. Lindqvist, "Fluxes of Mercury in the Swedish Environment: Contributions from Waste Incineration," presented at the ISWA [Specialized Seminar] Incinerator Emissions of Heavy Metals and Particulates, Copenhagen, 18-19 September 1985.

J.G.T. Bergstrom and J. Lindqvist, "Mercury Removal from Flue Gases from SYSAV's Waste Heat Boiler Plant in Malmo, (with extended abstract in English) Report DRAV Nr 20, January 1985.

169. [p.42]: "Leaching studies of the filter ash from the Malmo plant indicate that most of the mercury compounds captured are or have been transformed to insoluble compounds. An investigation of leaching of mercury from peat ash showed that very stable forms of mercury are formed. Tempering and leaching data indicate that compounds as stable as $\mathrm{HgS}$ must be present in the ash (Lindquist, 1984). This is of course very favourable for deposition of filter ash, since $\mathrm{HgS}$ would be stable in aerated soil and would not be dissolved from landfills or lake bottom deposits."

O. Lindqvist, "Fluxes of Mercury in the Swedish Environment: Contributions from Waste Incineration, " presented at the ISWA [Specialized Seminar] Incinerator Emissions of Heavy Metals and Particulates, Copenhagen, 18-19 September 1985.

O. Lindqvist, "Mercury in ash from peat combustion," THM Project Nr. 276 184-I, Statens Energiverk. 5-11787 Stockholm (1984). 
170. [p.43]: "Preliminary studies have indicated that mercury may be bound in stable forms in filter ash meaning that such ash could be deposited without serious environmental effects with respect to mercury."

O. Lindqvist, "Fluxes of Mercury in the Swedish Environment: Contributions from Waste Incineration," presented at the ISWA [Specialized Seminar] Incinerator Emissions of Heavy Metals and Particulates, Copenhagen, 18-19 September 1985.

171. [p.63]: "The mercury transported from the plant with the dust [fly ash] is strongly attached to the particles. Evaporation during handling and transport is of little significance. Measurements show that evaporation from the dust [fly ash] collected in the fabric filter is measurable in laboratory experiments, but this is not the case for the mercury collected with the dust [fly ash] in the ESP. Over a period of 14 days, from 10 to $15 \%$ of the mercury in the dust from the fabric is evaporated at room temperature. There is no difference in mercury content if the dust from the ESP is treated the same. There is a significant difference in chlorine content between the two ashes. Ash from the ESP has a chlorine content of about $15 \%$, whilst the ash from the fabric filter contains $35 \%$ chlorine according to the analyses."

\section{J.G.T. Bergstrom, "Mercury Behavior in Flue Gases," Waste Management and Research 4:57-64(1986).}

172. [p.7 1]: Ibased on discussions contained in the referenced report which precede this citation] "...it can be concluded that in the crude gas which has left the boiler outlet, mercury(II)-halogenides and, to a lesser extent, mercury(I)-halogenides (predominantly chlorides)must be expected to occur. The observed division of mercury into the gas phase and the ash fraction can thus be explained satisfactorily. Depending on the temperature, more or less mercury(II)-chloride is adsorbed on the fly ash and, following reduction to mercury(I)chloride, bound there (Braun et al. 1986).

"This thesis is in good agreement with the vaporization rates measured by us for various mercury substances as a function of the temperatures (Fig.3 [Shows vaporization rates of mercury and its compounds from fly ash]). The relatively large difference between $\mathrm{HgCl} 2$ [as the pure compound] and $\mathrm{HgCl} 2$ in fly ash is evident [figure indicates that pure $\mathrm{HgCl} 2$ is much more volatile than fly ash bound $\mathrm{HgCl} 2$ ]."

H. Vogg, H. Braun, M. Metzger and J. Schneider, "The specific role of cadmium and mercury in MSW," Waste Management and Research 4:65-74(1986).

H. Braun et al., "Mercury removal from flue gases of refuse incinerators," Mull und Abfall 18:62(1986). 
173. [p.72]: [re dry sorption methods that employ use of fabric filters] "...it should be mentioned in this context that lower temperatures [below ca 150 degrees Centigrade] may cause problems in process engineering, e.g., due to filter plugging."

H. Vogg, H. Braun, M. Metzger and J. Schneider, "The specific role of cadmium and mercury in MSW," Waste Management and Research 4:65-74(1986).

174. [p.72]: "If mercury(II) is to be removed in a [wet] scrubber, special attention, however, must be paid to the following (Braun et al. 1986). The scrubbing solution represents a reducing agent, probably on account of the interaction with $\mathrm{SO} 2$ present in the offgas at concentrations of $300-400$ milligrams/normal cubic meter. This can be proved in a direct manner by the discolouration of potassium permanganate solution. With increasing $\mathrm{pH}$ we were able to show, in laboratory investigations, that mercury(II) can be reduced to mercury(I) which, through disproportionation, can further react to become mercury(II) and mercury(0). The mercury $(0)$ thus formed follows the offgas and is discharged from the system. The reduction of the bivalent mercury can, however, be prevented by higher chloride concentrations and/or by a strongly acid scrubbing solution.

"From measurements downstream of the demister we could demonstrate the presence of mercury(0). We found a mercury(II):mercury(0) ratio of about $1: 1$. We interpret this as a direct sign that the reduction reaction actually occurs. Until now, details of this reaction have not been well understood, especially with regard to part of the system the reaction mainly takes place in. A wet scrubbing system is a very complex liquid/gas phase reaction system which is not in equilibrium, with largely differing gas compositions and varying droplet contents on the scrubber head compared to its outlet. Also not well understood is what happens on the way to the demister, where very small droplets could have a chance to react with the SO2.

"In order to prevent this deleterious reaction we recommend high acid and/or high chloride concentrations, and if possible, lower temperatures. By adding an oxidant the influences described above could be probably also counteracted. If one considers these findings, the yield of emission reduction for mercury would be much better than $80 \%$."

H. Vogg, H. Braun, M. Metzger and J. Schneider, "The specific role of cadmium and mercury in MSW," Waste Management and Research 4:65-74(1986).

H. Braun et al., "Mercury removal from flue gases of refuse incinerators," Mull und Abfall 18:62(1986).

175. [p.1]: [Abstract] [Results of analysis of combined așh stream from Stanislaus tests of carbon absorption technology]...the $\mathrm{Hg}$ content of ash/residue stream samples remained relatively constant over a period of 28 days in samples held at 54 degrees Centigrade (130 degrees Fahrenheit)." [NB the temperature selected for heating ash samples containing mercury is believed to correspond to upper end of elevated temperatures that could conceivably develop in an ash monofill (private communication from T. Brna, June 17, 1992)]

T.G. Brna, J.D. Kilgroe and C.A. Miller, ,U.S. EPA, "Reducing Mercury Emission from Municipal Waste Combustion with Carbon Injection into Flue Gas," Presented at ECO WORLD '92, June 1992. 
This page intentionally blank. 

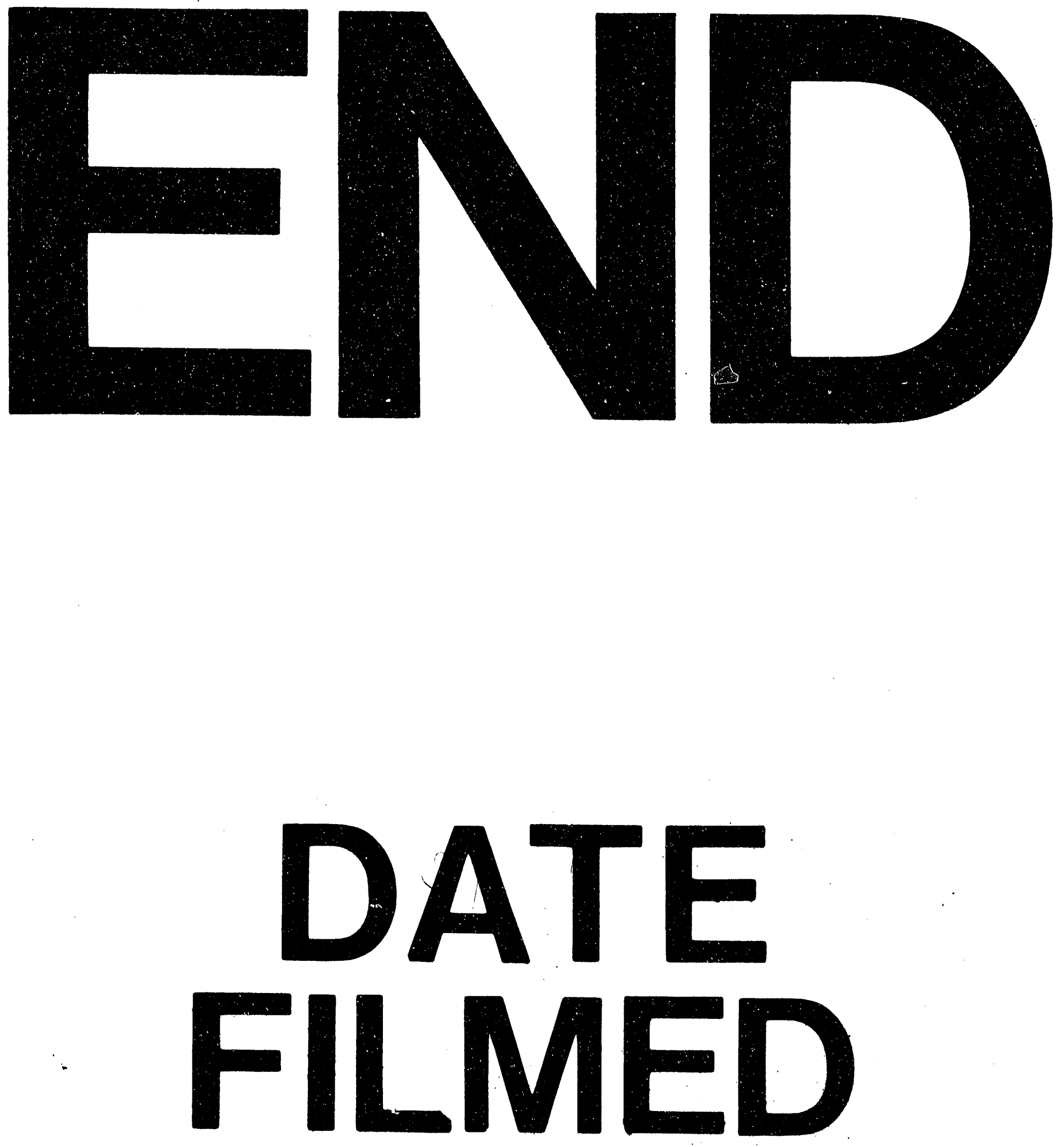

1

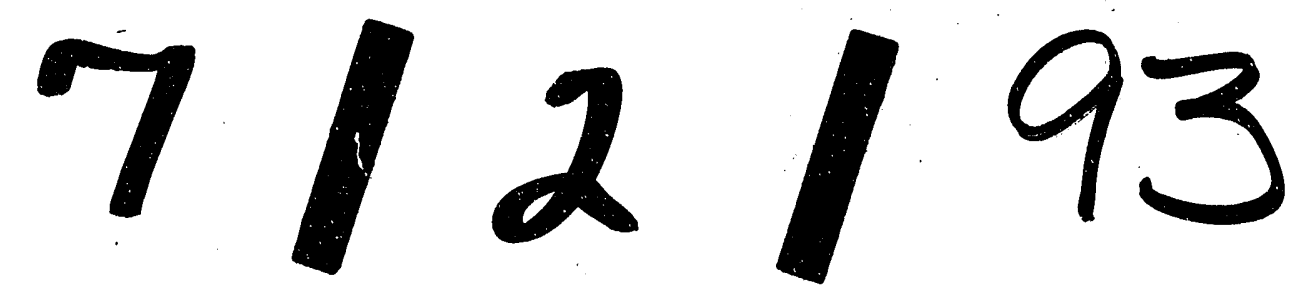


